Historic, Archive Document

Do not assume content reflects current scientific knowledge, policies, or practices. 



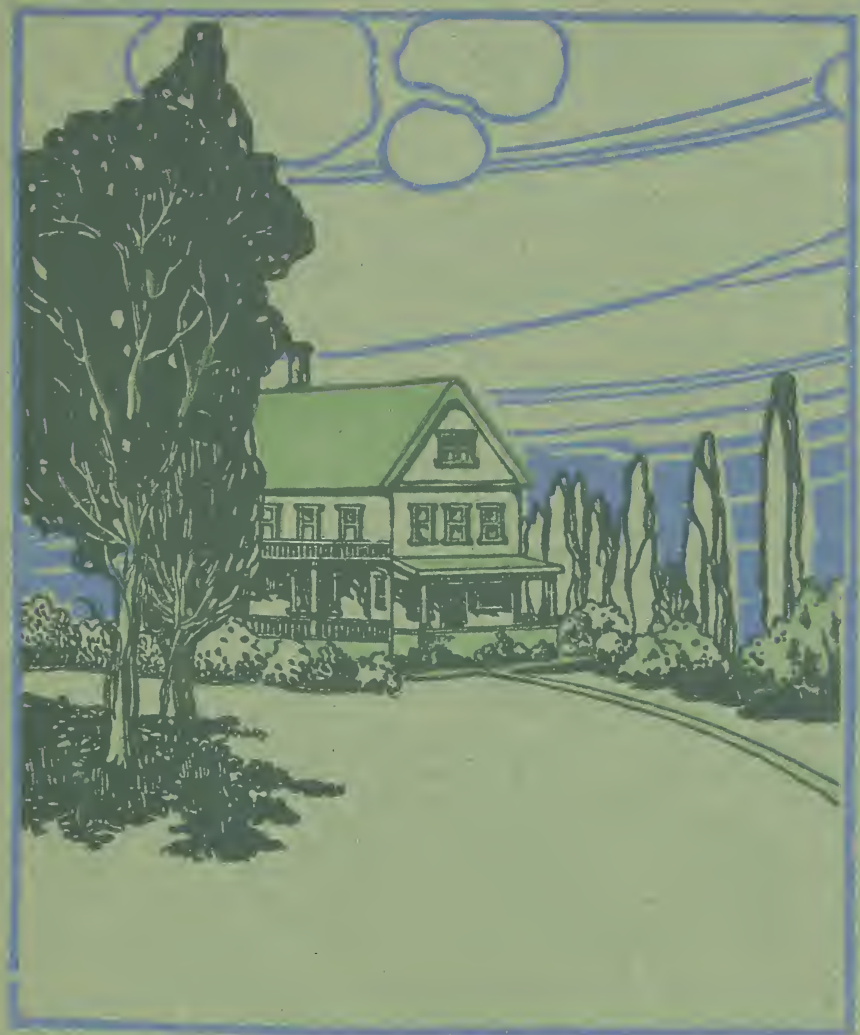

\section{Trees, Plants and Shrubs for the Northwest}

MCKAY NURSERY COMPANY MADISON, WISCONSIN 


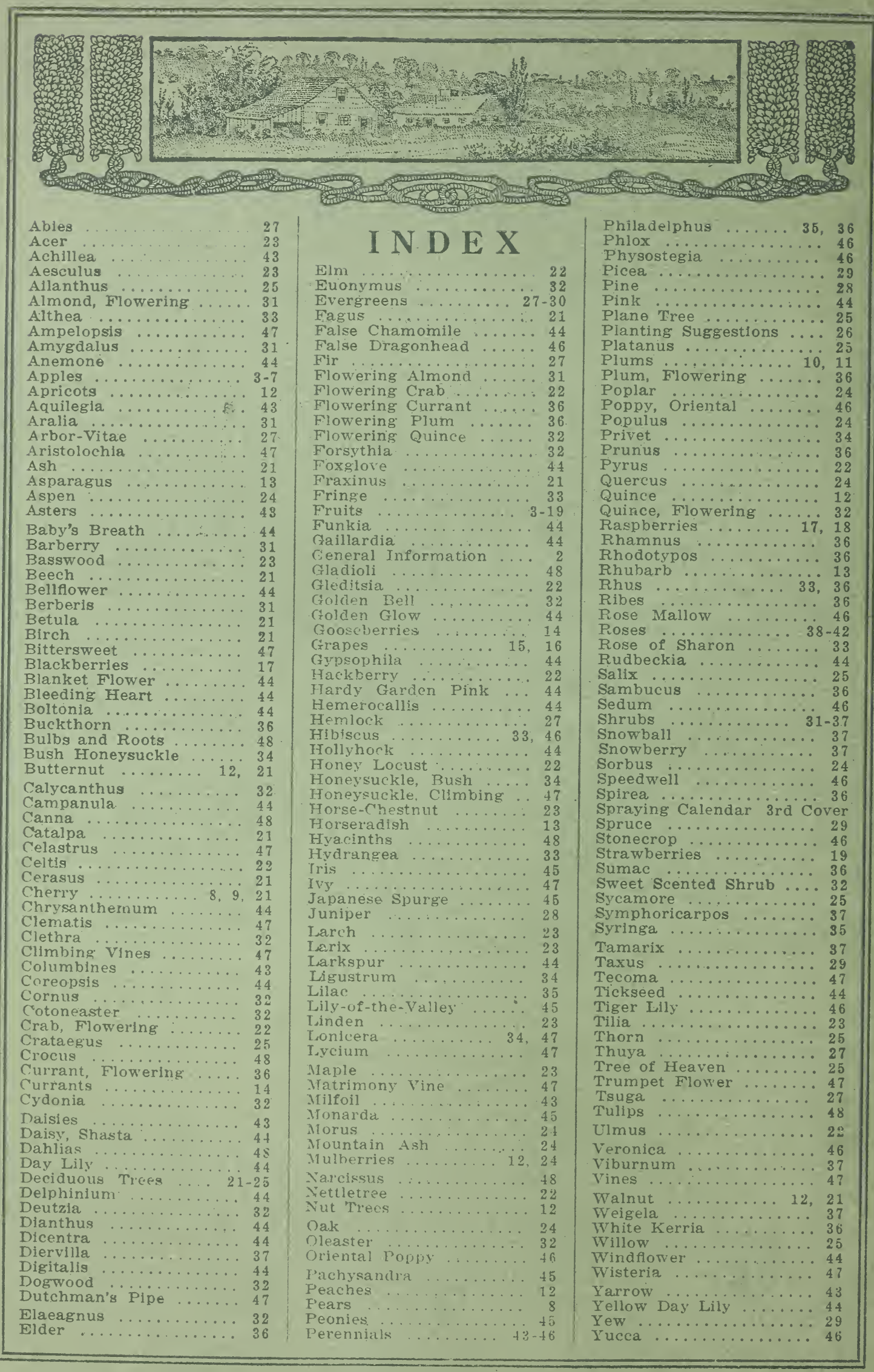




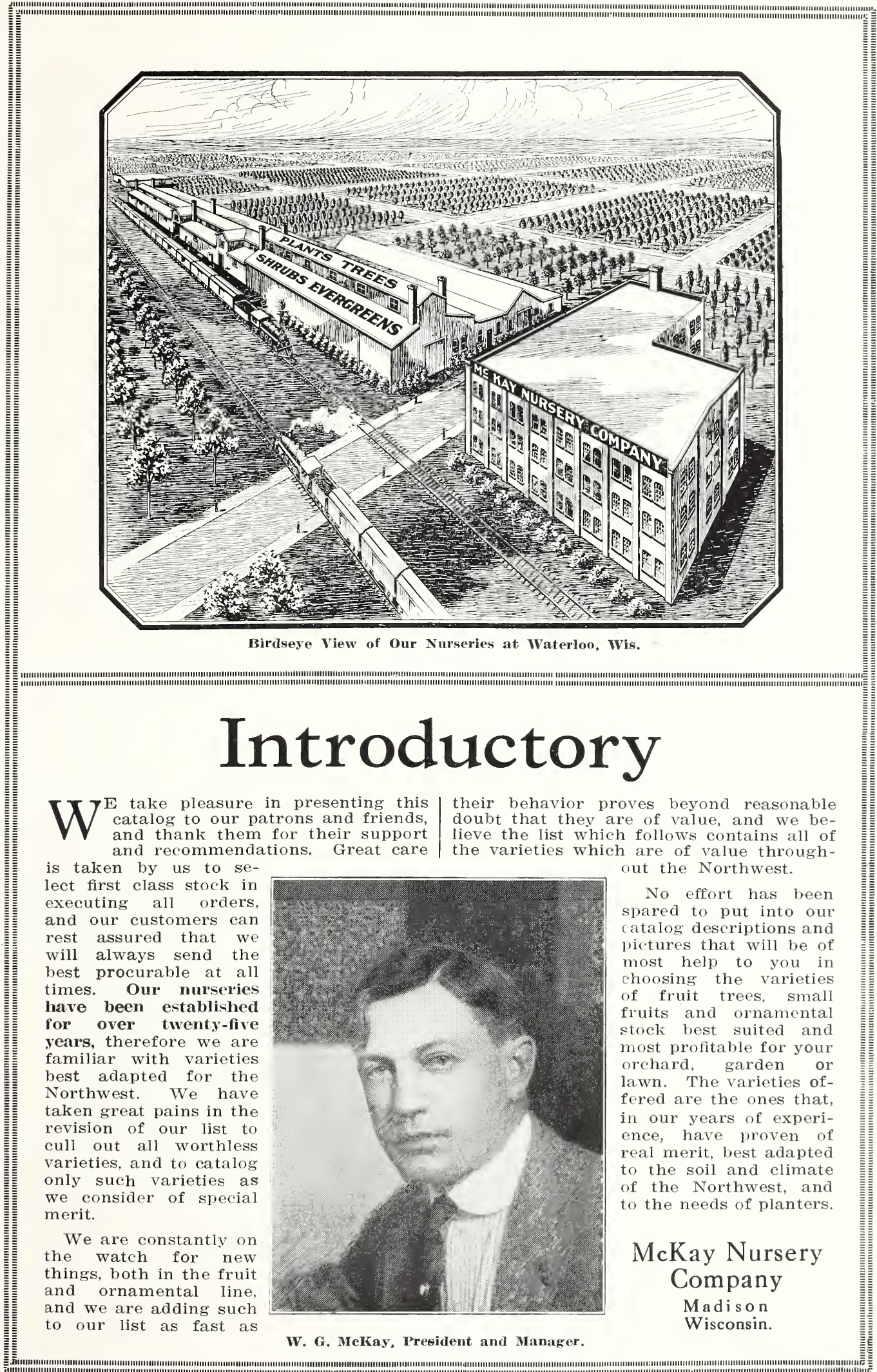




\section{General Information}

OFFICES AND NURSERIES. All correspondence should be addressed to Madison, Wis., where our main offices are located. Our nurseries are located at Waterloo, Wis., on the Chicago, Milwaukee \& St. Paul Railway, twenty-four miles east of Madison.

Our location furnishes a quality of soil best suited to produce the healthiest conditions of growth, with solid, firm texture of wood, with abundant fibrous roots, so necessary to successful transplanting, and enables us to offer the products of our nurseries with entire confidence to planters in all sections of the country.

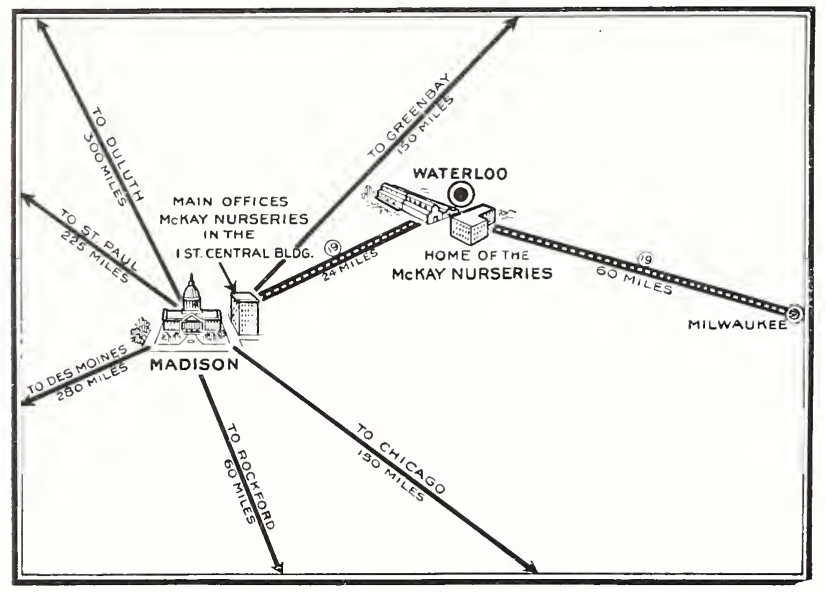

SITISFICTORY GUARANTEE. We guarantee our stock to be first class and to be delivered in good condition. We are most careful to have all plants and trees correctly labeled and hold ourselves prepared to replace, on proper proof, all that may prove untrue to label, or to refund the amount paid therefor; but it is mutually agreed between the purchaser and ourselves that, in case of error on our part, we shall at no time be held responsible for a greater amount than the original price of said stock.

IN ORDERING. Write the name, number and size of each variety plainly, so as to avoid errors, and use order sheet which accompanies catalog. In filling orders, we reserve the right, in case we are out of a variety ordered, to substitute another of equal merit, unless customer writes "no substitution" in the orJer. We recommend that purchasers leave the selection of varieties with us as far as possible, as our experience enables us to select such sorts as are best adapted to the locality.

It is also better to order early and have stock reserved. We are glad to book orders at any time of the year and make shipment when desired. We are the largest growers in Wisconsin of strictly first class nursery stock, therefore are in a position to give you satisfactory service.

INSPECTION. Our nurseries are annually inspected by the state entomologist, as required by law, and we hold his certificate that our stock is free from injurious insects and contagious diseases.

CARE OF STOCK IVHEN RECEIVED FROM THE NURSERY. As soon as the trees and plants are received, the bundles should be opened, removing all straw and packing, and the roots thoroughly sprinkled, then heeled in very moist ground, so that the mellow earth will come in contact with the roots and thoroughly protect them from the air, having earth tamped solid about them. Wet down thoroughly and cover wet soil with two or three inches of mellow earth. In planting take up only a few at a time and never allow them to lay exposed to air and sun.

THE PREPARATION OF THE SOIL. For fruit trees the soil should be dry, either naturally or made so by thorough drainage, as they will not live or thrive on a soil constantly saturated with stagnant moisture. It should also be well prepared by twice plowing, at least, beforehand, using the subsoil plow after the common one at the second plowing. On new, fresh lands, manuring will be unnecessary, but on lanđs exhausted by cropping, fertilizers must be applied, either by turning in heavy crops of clover or well-decomposed manure. To insure a good growth of fruit trees, land should be in as good condition as for crop of wheat, corn or potatoes.

THE PIRPARATION OF THE TREES. In regard to this important operation, there are more fatal errors committed than in any other. As a general thing, trees are planted in the ground precisely as they are sent from the nursery. In removing a tree, no matter how carefully it may be done, a portion of the roots are broken and destroyed, and consequently the balance that existed in the structure of the tree is deranged. This must be restored by a proper pruning, adapted to the size, form and condition of the tree.

On all fruit trees the branches should all be cut back to within three or four buds of their base. This lessens the demand upon the roots, and enables the remaining buds to push with vigor. Cut off smoothly all bruised or broken roots up to the sound wood. In case of older trees, of extra size, the pruning must be in proportion; as a general thing it will be safe to shorten all the previous year's shoots to three or four buds at their base, and where the branches are very numerous some may be cut out entirely.

\section{NUMBER OF TPEES OR PLINTS} ON IN ACRE

$\begin{array}{rrr}2 & \text { feet each way... } 10,890 \\ 3 & \text { feet each way... } & 4,840 \\ 4 & \text { feet each way . } & 2,723 \\ 5 & \text { feet each way. . } & 1,742 \\ 6 & \text { feet earh way . } & 1,210 \\ 8 & \text { feet each way... } & 680 \\ 10 & \text { feet each way . } & 430 \\ 12 & \text { feet each way... } & 302\end{array}$

15 feet each way
18 feet each way.
20 feet each way.
25 feet each way.
30 feet each way.
33 feet each way.
40 feet each way.

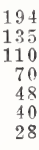

RULE. Multiply the distance in feet between the rows by the distance the plants are apart in the rows and the product will be the number of square feet for each plant or hill; which, divided into the number of feet in an acre $(43,560)$, will give the number of trees.

\section{SUITABLE DISTANCES FOR PLANTING} IN THE NORTHWEST

ples, Stand

Apples, Standard

Pears, Dwarf

Cherries

Plums

Peaches and Apricots

Currants and Gooseberries

Raspberries and Blackberries

20 to 30 feet 16 to 20 feet 12 to 15 feet 16 to 20 feet 16 to 18 feet 16 to 18 feet 4 to 6 feet 4 to 6 fee

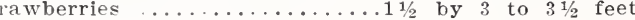




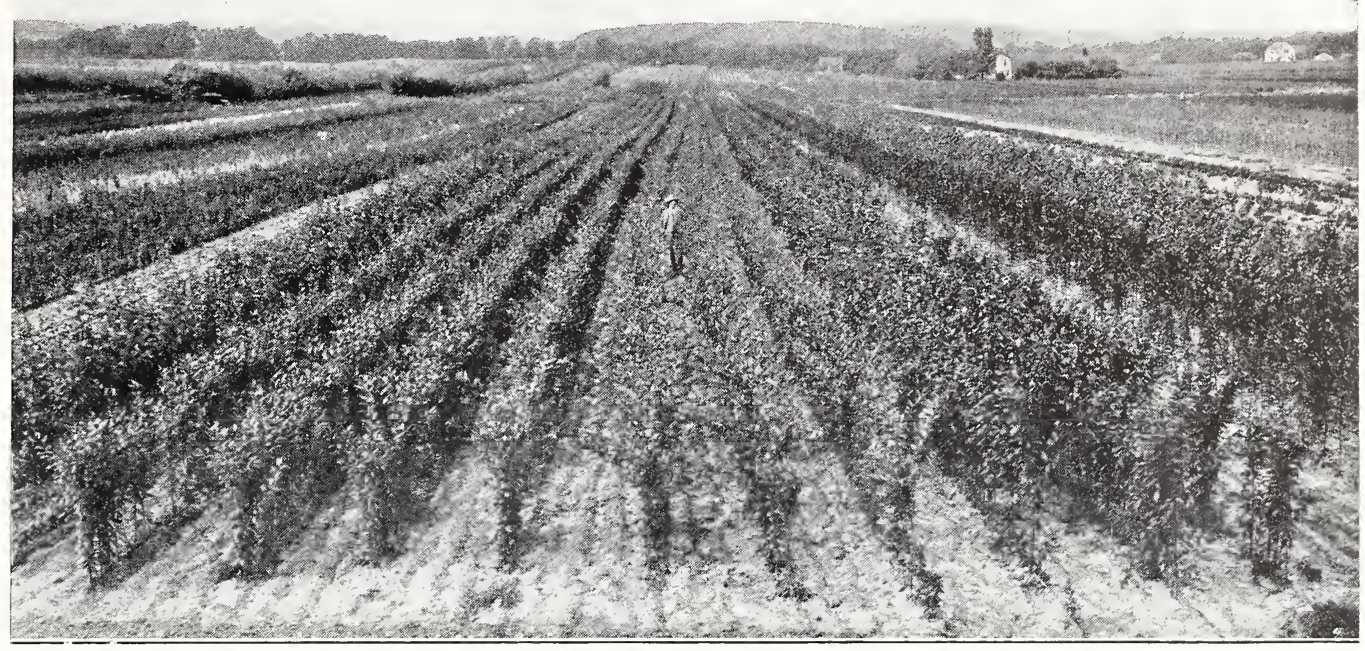

A Field of Fruit Trees in Our Nurseries.

\section{Fruit Department}

\section{Apples}

The Apple has been justly styled "The King Fruit of the Temperate Zone." No other fruit is so widely grown or has such universal demand. No other fruit offers so many variations in quality and usefulness. None other gives such a long period for its enjoyment as a fresh fruit - very late keeping varieties lasting over until the early sorts of the following season are ripe.

We grow Apple trees for particular planters. Our trees are dug, graded and packed by ex. perienced men. There is an extensive area in Wisconsin adapted for commercial fruit growing The necessary requirements are fertile, well drained soil, proper selection of varieties and the purchasing of healthy, well grown stock from a reliable nursery company. By following the above suggestions, success will crown your efforts.

The more hardy varieties are marked with a star (*) and will give good satisfaction in the Northwest.

\section{Summer Varieties}

*Duchess (Oldenburg). A large, beautiful Russian Apple, round, streaked red on yellow ground; tender, juicy, very acid. Fine for cooking. Bears early; productive. September.

Early Harvest. Medium to large; pale yellow; tender, with a mild, fine flavor. One of the first to ripen. Middle to end of August.

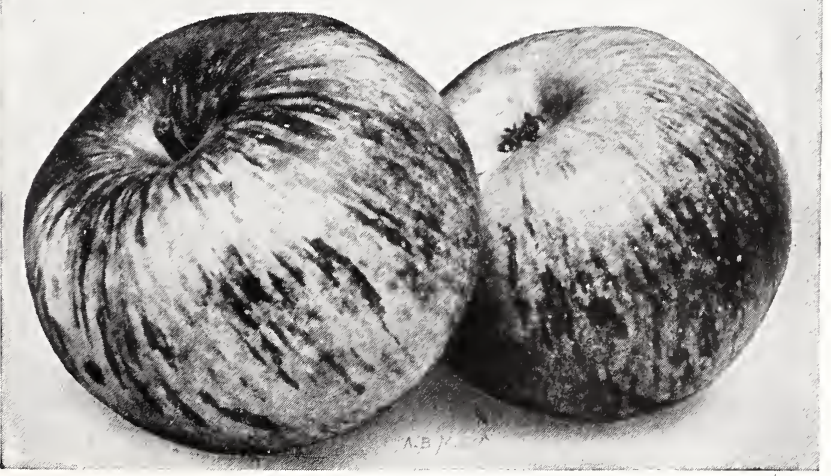

Duchess (Oldenburg) Apples.
Golden Swcet. Large, yellow; a very fair, fine, sweet Apple. Spreading, irregular, and productive. August and September.

*Liveland (Lowland Raspberry). Of Russian origin; color white, shading to crimson; flesh white; tree hardy, long-lived and succeeds very well North and South: very juicy and sweet. July to August.

Red Istrachan. Large, roundish, nearly covered with deep crimson, overspread with thick bloom. Juicy, rich acid, beautiful; a good bearer. August.

*Yellow Transparent. Medium, white, changing to lemon-yellow smooth waxen surface; of good quality, with crisp flesh; very early, and for an early Apple, an unusually good keeper. Valuable for market. July and August.

We use up-to-date, progressive methods in the growing, protection, care and handling of all stock, thus doing away with failure on the part of the planter. 


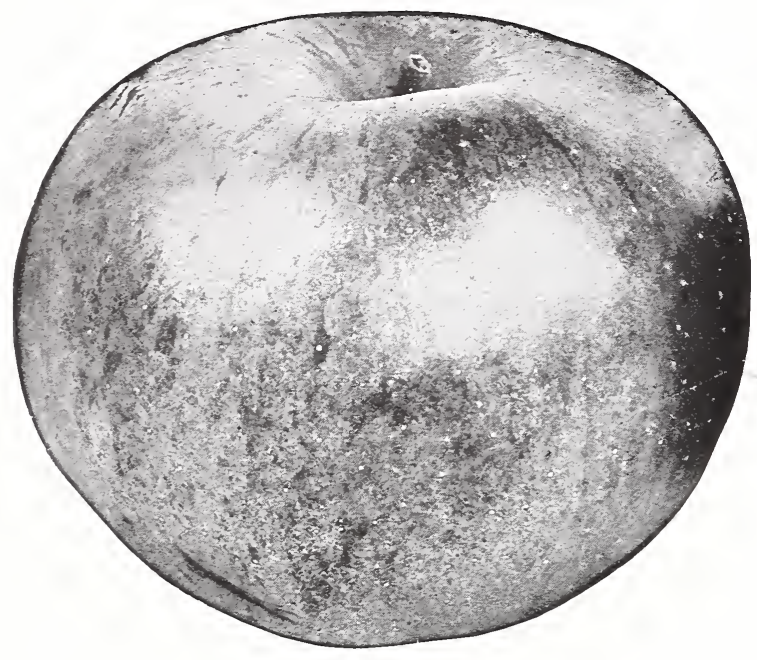

Wealthy Apple.

\section{Autumn Varieties}

*Erickson. Originated at Aitkin, Minnesota. The Apples were first exhibited as seedlings at the Aitkin County Fair, receiving first premium. Trees have been planted as far north as the Canadian line and have shown no signs of Winter injury. It appears that the Erickson is as hardy as the Hibernal. Fruit ripens after the Duchess, very large, ranging 3 to inches in diameter; color greenish yellow striped: flesh white; flavor is a pleasant mild sub-acid. This variety is recommended where hardiness is of first consideration.

*Hibernal, Origin, Russia. Season November and December. This variety represents what is probably the hardiest type of the Russian race: adopted by many prominent horticulturists as a standard of hardiness. Tree is sturdy. vigorous, very spreading and productive.

*McMahon. Large, round; almost white with faint blush: a very beautiful Apple: flesh white, tender, tart, not very firm. A good cooking fruit. Tree vigorous and hardy as crab; bears young and abundantly. October to February.

Maiden Blush. Large, flat; pale yellow, with red cheek: beautiful, tender and pleasant, but not high flavored. An erect grower, and a good bearer. Taluable for market. September and Detober.

*Patten's Greening. Tree rather crooked, extremely hardy, productive and an early bearer: fruit large and smooth; olive-green, blushed with dull red; flavor pleasant, subacid. A superior cooking Apple. October to December.

Plumb Cider. A variety introduced by J. C. Plumb, of Milton, Wisconsin. The tree came originally from Ohio, probably in 1844. It is vigorous, an early bearer, and very productive in alternate years. The flesh is greenish white fine grained, firm, juicy, sub-acid, of very good quality. November to January.

*Wealthy. Origin, Minnesota. Season October to March. Almost too well known to need description. Since its origination by the late Peter M. Gideon in 1861 , it has rapidly spread over the entire country until now it is extensively planted in all the Apple growing states. Fruit large, regular, smooth, light yellow with crimson stripes and splashes; flesh white, often stained with red, tender, very juicy, sprightly sub-acid with delicious aroma Splendid dessert and cooking Apple. Market demand never filled.
*Wolf River. Season October to January. one of the very largest Apples grown in the North Color yellowish green with stripes and splashes of carmine; very handsome and showy; flesh nearly white, firm and rather coarse grained; flavor sub-acid, fair to good.

\section{Late Fall and Winter Varieties}

Baldwin. Large, roundish; skin deep red; flesh juicy, crisp, sub-acid, good flavor. The best all around Winter Apple for New England and the eastern states. Keeps splendidly. December to March.

* Bayfield. One of the famous Perkins seedlings known as No. 124. The tree is a very rapid grower, bearing large, red Apples of splendid quality that will keep well up to May 15 th. This variety is destined to be one of the best Winter Apples grown in Minnesot? and well adapted for large commercial orchard planting.

Ben Davis. The great market Apple of the West and South, largely planted also in the East. One of the best for profit. It is a splendid keeper, and fine for cooking. December to April.

Delicious. (See color engraving on page 7 ). originated in Iowa and has every appearance of being hardy, with strong branches capable of bearing large crops of fruit. The Apple is striped and marked with bright and dark red. This variety has a delightful flavor and is extremely valuable for either home or commercial orchard. It is a long keeping winter Apple with a season from December to May.

* Dudley (North Star). Much like Duchess, only it is a Winter Apple; less tart and better quality. Perfectly hardy in the coldest climate. Originated in Northern Maine and there considered their finest Apple. Valuable for the North.

*Folwell (Minnesota No. 237). Seedling of Malinda. Originated at the Minnesota Fruit Breeding Farm. Tree very vigorous, free growing with a strong branching habit; annual bearer and hardy in the Northwest. Fruit roundish in form, very large, about the size of the Northwestern Greening: color greenish yellow blushed with red; flesh tender; moderately fine grained, pleasant, sub-acid flavor; quality rery good. Keeps until mid-Winter.

Gano. Similar, but superior to Ben Davis. It has all the good qualities in a higher degree, more brilliant colorings, runs more even in size and keeps fully as late. February to March.

Golden Russet. Medium, very tender, juicy, rich, sub-acid: high quality. October to January

Grimes' Golden. Medium to large size, round, rich golden yellow, sprinkled with light gray dots; flesh crisp, tender, rich and juicy, sprightly. January to April.

*Goodhue. This variety of the famous Perkins seedlings is a splendid mid-Winter Apple that will keep until February. It is larger than the Red Wing, has the same color markings, only slightly more pronounced. It is a much hardier, more vigorous tree than the Wealthy and superior as an eating and cooking Apple. Like the Red Wing, it has swept the boards of the Minnesota State Fair and Horticultural Society meetings for the past eleven years.

* Haralson. Originated at the Minnesota Fruit Breeding Farm. Tree vigorous, upright in growth and very hardy; fruit large size, colored with an even red over the entire surface; flesh fine grained, tender, juicy, sub-acid, good quality. Keeps until early Spring. A valuable addition to the list of Winter varieties for the North. 


\section{LATE FALL AND IVINTER VARIETIES-- Continued.}

*Jumbo. The largest of the famous Perkins seedling Apples, has markings similar to the Red Wing and Goodhue, is vigorous, hardy and a splendid bearer. It is a good substitute for Wolf River in size, but superior in quality of fruit, which keeps until January. The Jumbo was also of the collection that carried off the Wilder and Gold Medals at Boston and St. Louis in 1903.

Jonathan. Medium, roundish; yellow, nearly covered with red; fine grained, tender, and finely flavored. Tree slender and spreading, with light colored shoots. November to April.

King (King of Tompkins County). Very large, red striped, handsome fruit of fine quality, with juicy, tender and rich flavor. Tree is an abundant, annual bearer and succeeds best in the northern states. December to March.

*Longfield. A very hardy Apple; early and abundant bearer. Fruit large, conical, yellow striped with red, sub-acid; in season during the Fall and early Winter.

McIntosh. (See color engraving on page 6). Origin, Ontario, Canada. Season December and January. A choice variety of the Fameuse type. Tree vigorous, with spreading head; a good annual bearer. Fruit above medium to large, highly perfumed; smooth, polished yellow, almost covered with brilliant solid crimson, a beautiful fruit; flesh snowwhite, crisp, very tender, sprightly, aromatic, sub-acid; very good quality.

Northern Spy. Large, roundish conical, often flattened, slightly ribbed; handsomely striped with red; flavor rich, aromatic, mild sub-acid, fine. Keeps through Winter and late into Spring.

* Northwestern Greening. (See color engraving on next page). Origin, Wisconsin. Season December to June. Tree a splendid, vigorous grower. Fruit large to very large; green, beconing yellowish green when ripe; flesh yel low, fine grained and firm; flavor a good subacid; very smooth and attractive, and taking a place second only to the Wealthy as an all around market Apple.

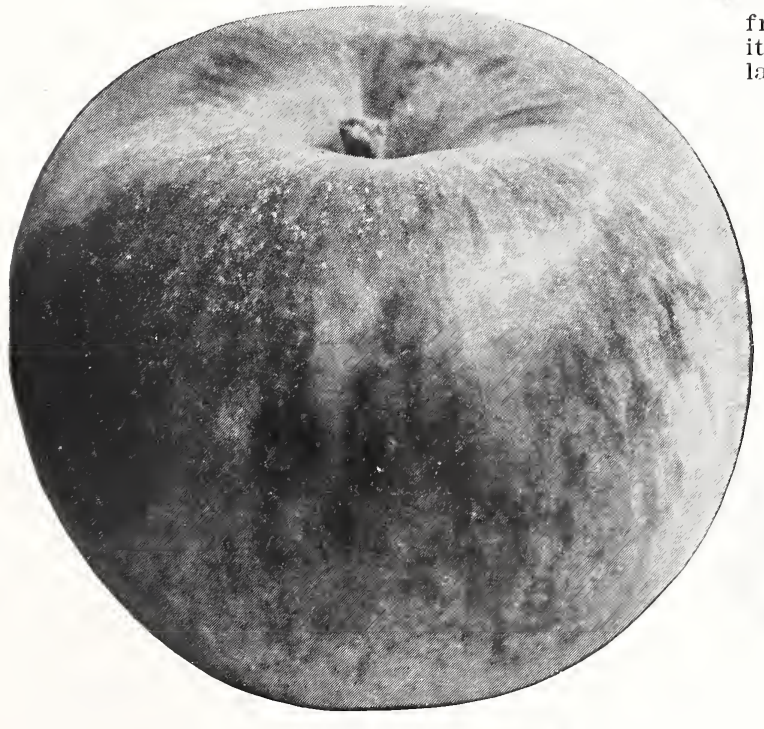

Dudley Apple.

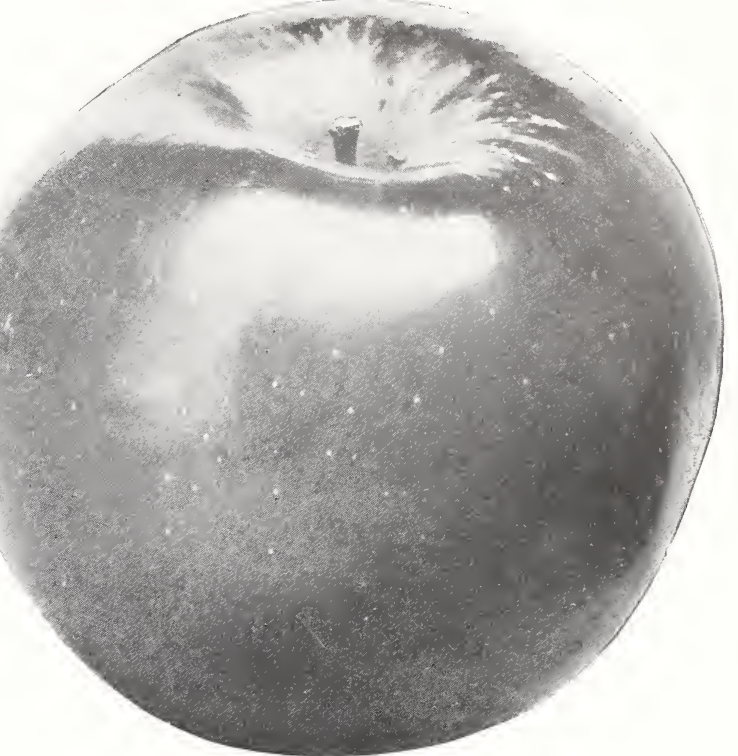

Haralson Apple.

Newell's Winter. Originated in Wisconsin about sixty miles north of Madison. It is a seedling of the Perry Russet. The fruit is large, roundish oblate, and of a rich yellow color; flesh firm, juicy, yellowish, rich, sprightly and sub-acid.

* Peerless. Origin, Minnesota. Season October to December. Fruit medium to large: yellowish green with stripes and splashes of carmine; flesh yellowish white, fine grained; flavor agreeable sub-acid but not rich. Tree vigorous, upright.

*Perkins. Originated by T. E. Perkins of Rea Wing, Minnesota. Perfectly hardy as far north as the Twin Cities. The fruit is large, red and round as a ball; flesh is fine grained. with a delicious flavor. Season October to April.

*Peter. Originated at Excelsior, Minnesota, from seed of the famous Wealthy. In quality its equal, and in season from four to six weeks later. The tree is a strong, upright grower.

Pewaukee, Origin, Wisconsin Season December to March. Tree spreading, round topped and vigorous. Fruit large, yellowish green, striped and shaded with dull red, overlaid with a bluish bloom. Flesh yellowish, firm, juicy; flavor sub-acid.

* Red Wing (See color engraving on next page). Originated by T. E. Perkins of Red Wing, Minnesota. It is a long keeping Winter Apple, slightly larger and finer in appearance and quality than the Wealthy, streaked with red on a yellow background, and shaped like Malinda; has enough acid to make it cook nicely. The Red Wing has taken the highest premiums at the Minnesota State Fair for the past eleven years, besides taking the Wilder Medal at the meeting of the American Pomological Society at Boston, Mass., in 1903, in competition with all of North America, and the Gold Medal at St. Louis World's Fair the same year, in competition with all comers. The parent tree bore $24 \frac{1}{2}$ bushels of Apples in 1913. Will keep until May.

Rome Beauty. Large, yellow and bright red; medium quality. December to March. Not very hardy in Wisconsin. 


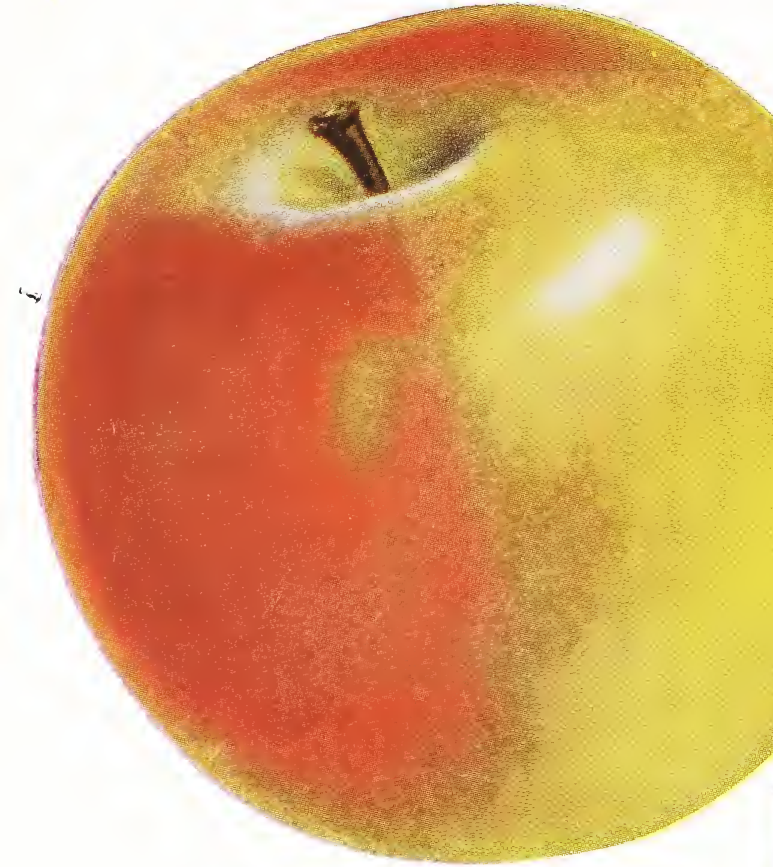

Northwestern Greening Apple. (See page 5).

\section{CATE WINTER VARIETIES-Continued.}

salome. Tree is hardy in Southern Wisconsin, vigorous and a good bearer; fruit round; skin pale yellow, shaded and splashed with red. A good variety for the Northwest. Season January to May.

Scott's Winter. Originated in Vermont, and is hardy in the severest climate. Tree a thrifty

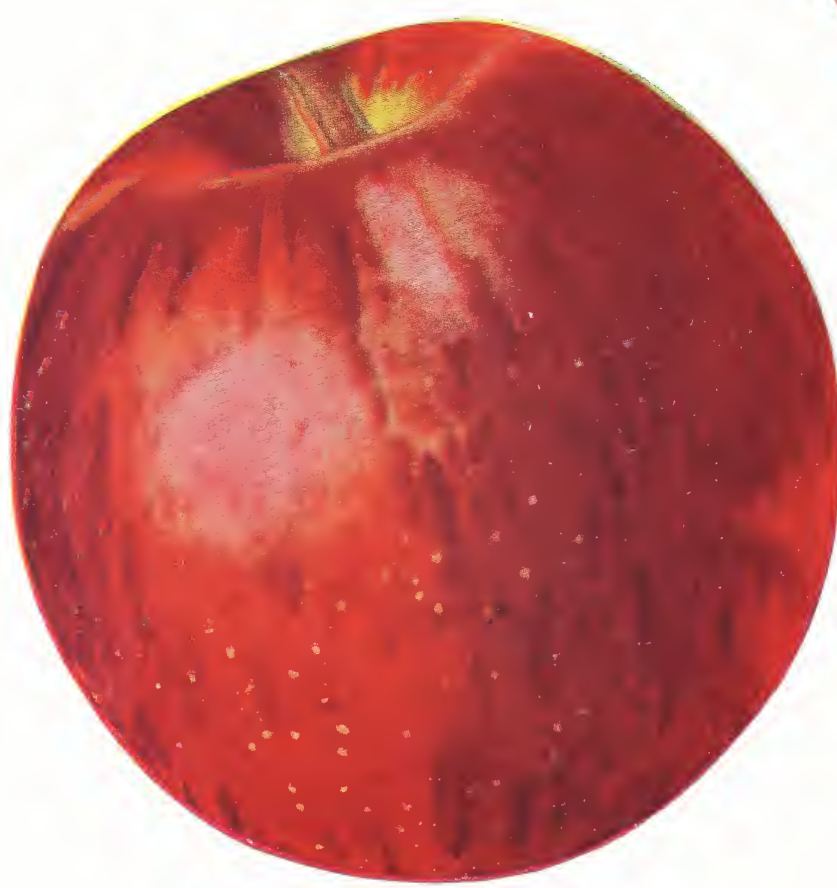

McIntosh Apple. (See page 5).

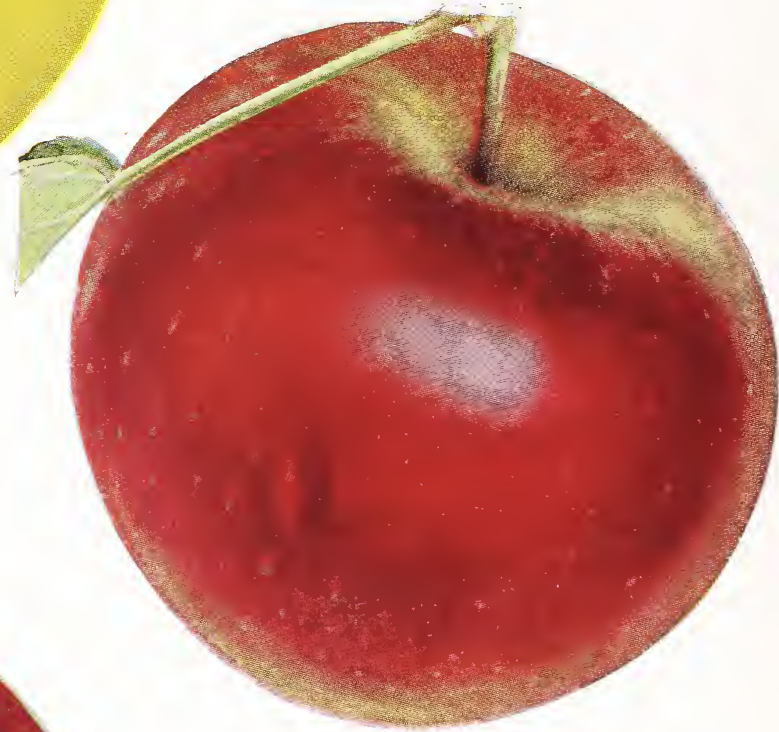

Red Wing Apple. (See page 5).

Tolman Sweet. Medium, pale whitish yellow; flesh white, fine grained; very hardy and productive. The best Winter sweet Apple for home and market. November to March.

*University. A seedling of the Duchess. Tree is a very vigorous and spreading grower; fruit large, very regular; surface a clear yellow on sunny side; flesh sub-acid; quality good. Tree hardy.

Walbridge. Of medium size; pale yellow striped and shaded with red; flesh crisp, tender and juicy; handsome and of good quality; late keeper. Tree very hardy, vigorous grower and productive. Considered of great value to growers in the North and Northwest. January to May.

Windsor Chief. A great favorite in Wisconsin. Keeps until March. Medium size; red; excellent quality; good for cooking or eating out of hand; splendid commercial variety. Tree considered hardy. 


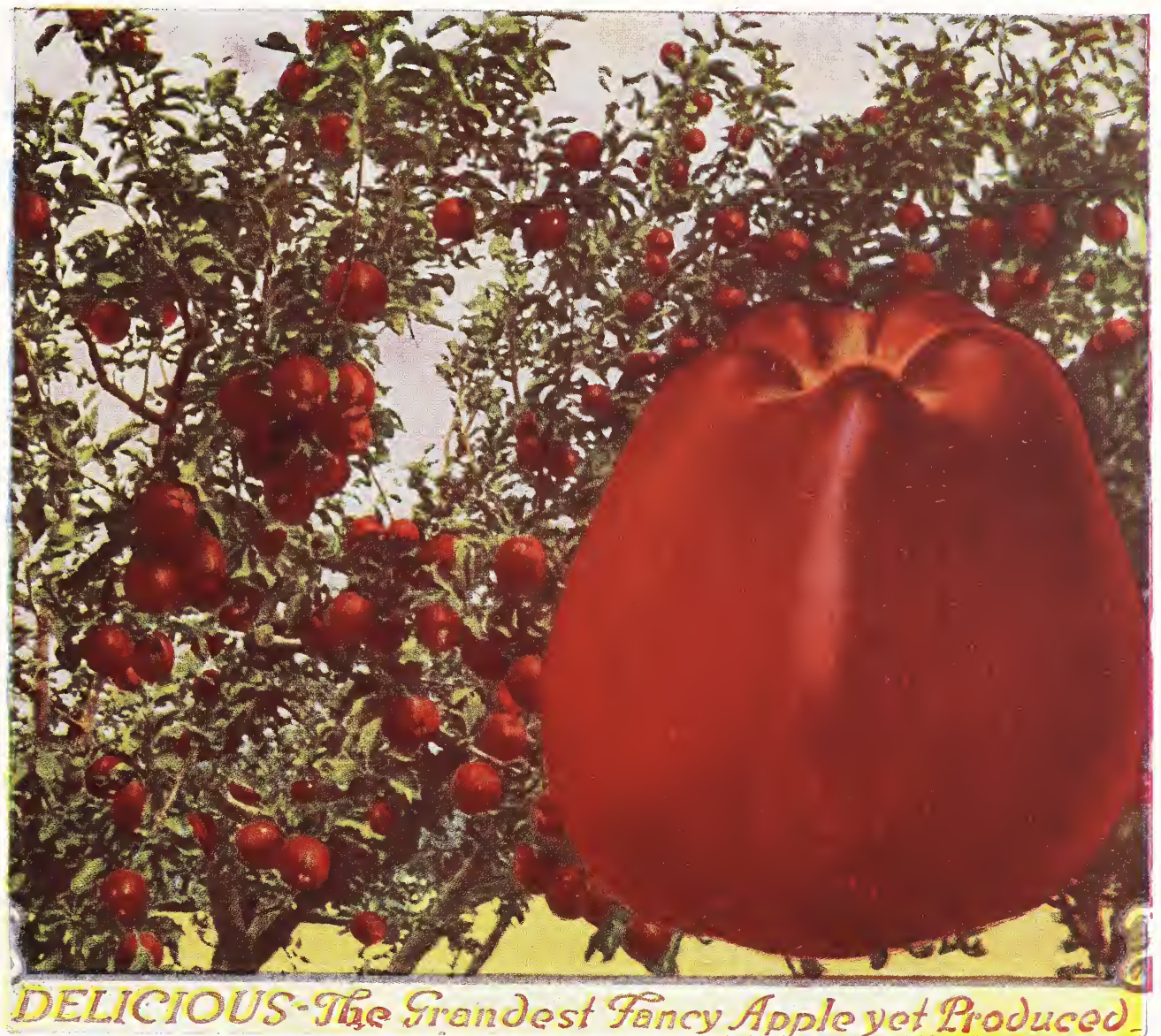

\section{Crab Apples}

The hardy and improved varieties of Crab Apples, some of which are of recent introduction and promise great excellence, supply a much needed want in the more northern portions of the United States and Canada, where little else in the line of fruit can be grown. And even in the more favored localities, where other fruits are grown in abundance, Crab Apples are every year becoming more esteemed and cultivated.

Hyslop. Red, not striped; fruit large, roundish ovate, produced in clusters; color dark, rich red, covered with thick blue bloom; flesh inclined to yellow, sub-acid. Tree hardy and vigorous. November.

Martha. Origin, Minnesota. Season September and October. Another of Peter M. Gideon's famous originations and one of the most largely planted Crabs today. Fruit large, yellow with heavy blush of light red; flesh fine grained, firm; flavor sub-acid, very juicy and exceptionally fine for cooking.

Minnesota. Season October to January. One of the most desirable. Fruit large, light yellow, often splashed or mottled with blush on sunny side when allowed to fully ripen; flesh cream white, fine grained, juicy; mild sub-acid, aromatic. Delicious to eat out of hand and desirable for culinary purposes.

Red Siberian. Large, strong grower; pale red-yellow; good quality. Tree large, with coarse foliage; young bearer.

Transcendent. A beautiful variety of Siberian Crab. Red and yellow. August. Tree bad blighter.

Whitney (Hybrid). (Whitney No. 20). Season August and September. Fruit large to very large for a hybrid; yellow, striped with red and mostly covered with red on sunny side; flesh yellow, very juicy and fine grained; flavor rich and almost sweet.

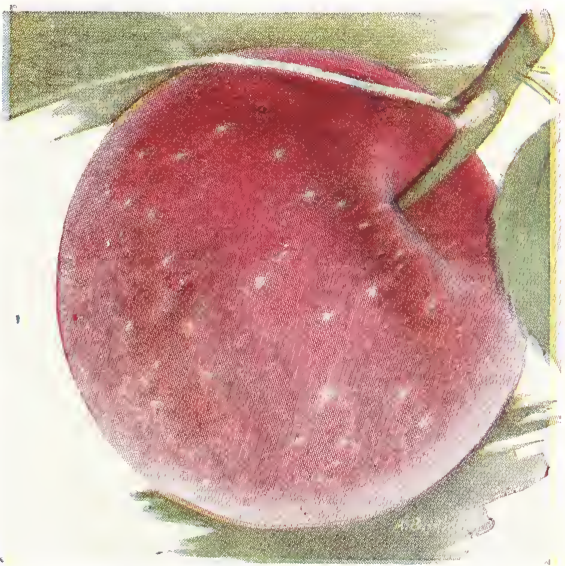

Whitney Crab Apple. 


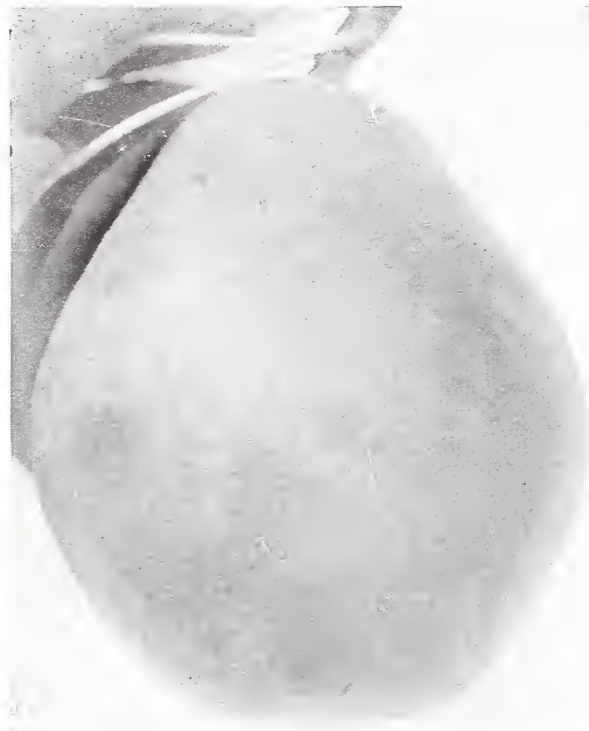

Kieffer Pear.

\section{Pears}

We do not recommend Pears for general planting in the Northwest; however, there are many localities where they do well. They succeed best in a well drained clay soil. The list selected is reduced to such as have been well tested and proved valuable. We recommend the Duchess as a dwarf variety.

Bartlett. Large, buttery and melting, with very rich flavor. A vigorous and erect grower: bears young and abundantly. Niddle of Sept.

Clapp's Favorite. Very large; color yellowish green to full yellow when ripe; marbled with dull red in the sun; covered with small specks. Nielting and rich; should be gathered early; tree vigorous. August and September.

Duchess d'Angouleme. Generally planted as a dwarf and is more valuable when so planted: very productive; fruit very large and somewhat irregular: color dull greenish yellow: of good flavor and very juicy. September to October.

Flemish Beauty. Large, beautiful, melting, sweet. Very hardy and fruitful. September and October.

Kieffer. The tree has large, dark green, glossy leaves, and is of itself very ornamental. It is an early and very prolific bearer. The fruit is of good quality when thoroughly ripe. Valuable for table and market. October and Tiecember.

Seckel. The standard of excellence in the Pear: small but of the highest flavor. Tree a stout, slow, erect grower. September to October.

Vermont Beauty. Tree hardy, healthy and productive. Fruit medium size skin yellow nearly covered with carmine; excellent quality. October.

\section{Cherries}

Possibly no fruit is attracting more attention at the present time than the Cherry. Fruit growers in parts of Wisconsin have been able to get a return of from eight hundred to one thousand dollars per acre. The leading commercial varieties are Early Richmond and Large Montmorency. Cherries bear young; the third year after planting, orchards that have received proper care will bear enough fruit to pay entire cost of trees and cultivation up to that time.

\section{Hardy Varieties}

Early Richmond. Probably the most popular variety of the Central States, where it is the hardiest Cherry of its size. Exceedingly productive and very regular in bearing. The fruit is dark red, medium to large, and of a sprightly and characteristic flavor. Unsurpassed for pies, puddings, and other similar uses. June.

English Morello. An old and popular variety. Tree rather dwarf and slender. Fruit large, dark red, nearly black; flesh tender, juicy, sprightly acid, rich. July.

Montmorency, Large. Tree very hardy and immense bearer; commences to fruit while young and is loaded annually with fine crops; fruit very large, fine flavor, shining red; valuable everywhere; a week later than Early Richmond; finest acid Cherry.

Wragg. Large, roundish, heart-shaped; dark crimson and when fully ripe, black or nearly so; flesh and juice light crimson, firm and good, very productive; one of the hardiest and is usually a sure cropper.

\section{Semi-Hardy Varieties}

Black Tartarian. Very large, color purplish black; flesh mild, sweet, jelly-like. Tree a vigorous grower and immense bearer. One of the most popular. Late June and early July.

Governor Wood. Large, rich, light yellow with red cheek; juicy and sweet. Late June.

Windsor. Very large, liver colored; finest quality; very vigorous and productive. Firm and excellent for shipping. Very late.

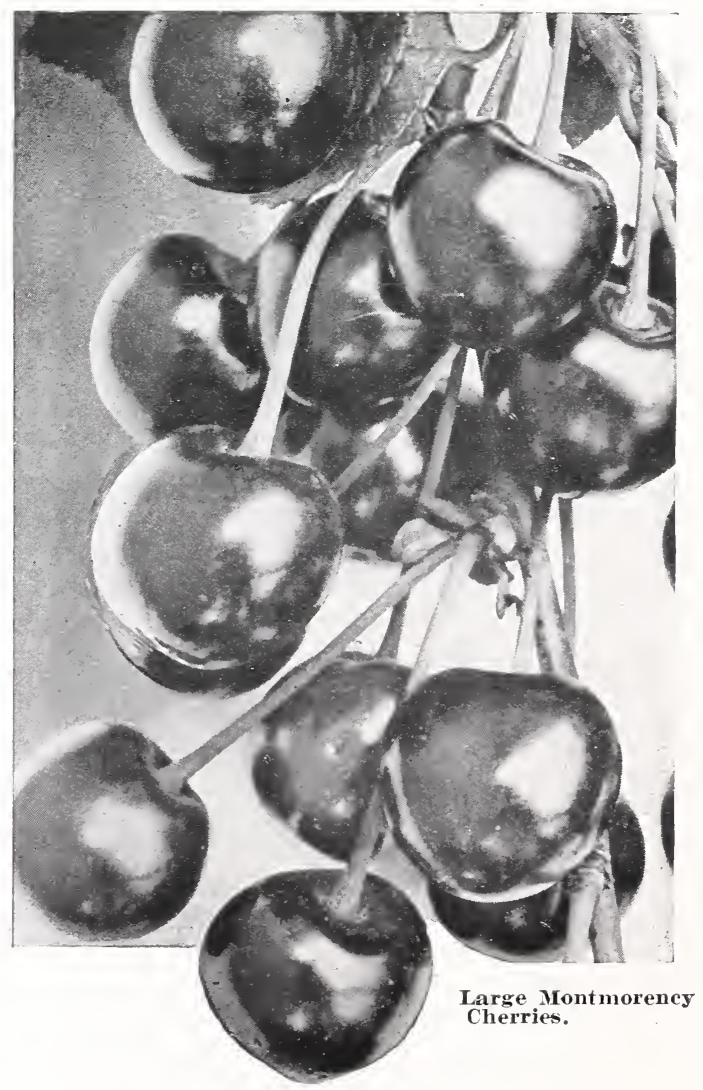




\section{Prof. Hansen's Cherry-Plums}

Prof. N. E. Hansen of the State Experiment Station, Brookings, S. D., one of the leading horticulturists in America and authority upon horticulture in the Northwest, has been an extensive traveler and was sent by the government to siberia to select hardy varieties of seeds and fruits which would be adapted to the severe climatic conditions. His explorations and experiences have resulted profitably to the people of this country. He has originated new fruits of great value and importance to all sections of the Northwest. The varieties we offer have been thoroughly tested in the North and have proved perfectly hardy even on the bleak prairies of North Dakota.

Opata (Sioux Indian name for Bouquet). A cross between the Dakota Sand Cherry and the Japanese Gold Plum. Tree is a good grower. an early and heavy bearer. The fruit is one inch or more in diameter and is excellent for eating out of the hand as well as for table and cooking purposes. It is a dark purplish rea with blue bloom; pit small; flesh green and firm and partakes of the rich sweetness of the Gold Plum. In Minnesota it bears as early as the last of July or first week in August.

Sapa (From Indian word meaning Black). A cross between the Dakota Sand Cherry and the Japanese Sultan Plum. Tree moderately free grower and naturally rather crooked when young. The color of the fruit is a glossy dark purple and the flesh is rich, dark red, size one inch or more in diameter. The fruit buds often set heavy the first year, bearıng quite a crop the second year. The five- to six-foot trees will bear the next year after they are transplanted.

\section{Compass Cherry-Plum}

Compass (Originated by M. H. Knudson, Springfield, Minnesota). A cross between the Dakota Sand Cherry, Morello Cherry and Miner Plum. It is absolutely hardy, wonderfully prolific, frequently producing fruit on young trees in nursery row. In shape, size and coloring of

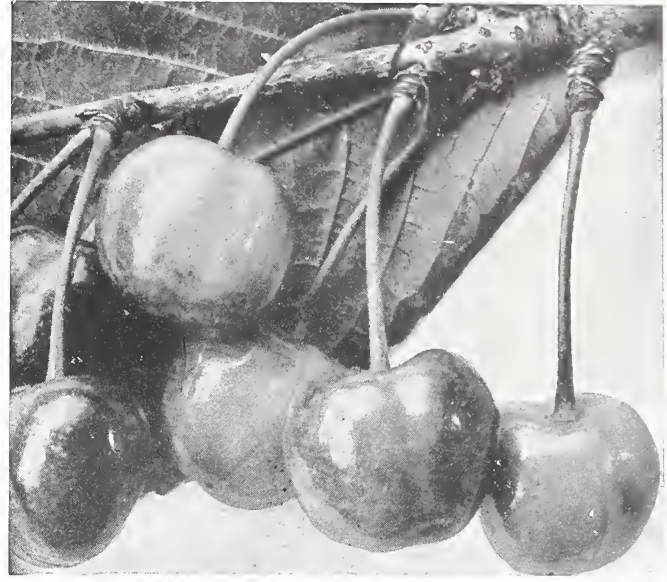

Early Richmond Cherries.

the fruit the characteristics of the Plum and Cherry are about equally divided. Color bright red, deepening as it becomes well ripened, until it reaches a rich, dark wine color. Valuable for canning and preserving.

Zumbra Cherry. The Minnesota Fruit Breeding Farm originated the Zumbra. This variety is extremely hardy and suitable for planting where other varieties of Cherries will not thrive. This Cherry ripens in August and has a flavor similar to the black Sweet Cherries so extensively grown in milder climates. The fruit reaches a size of one inch in diameter, and is borne on the previous year's wood; color very dark, nearly black when ripe; flesh firm, sometimes tinged with red when fully mature; especially recommended for sauce and preserves. The tree is a low grower and rather on the dwarf order. This adapts it for planting in small corners of your garden or orchard. It has early bearing and extremely productive habits. Trees set out in the spring bear heavy crops the following year.

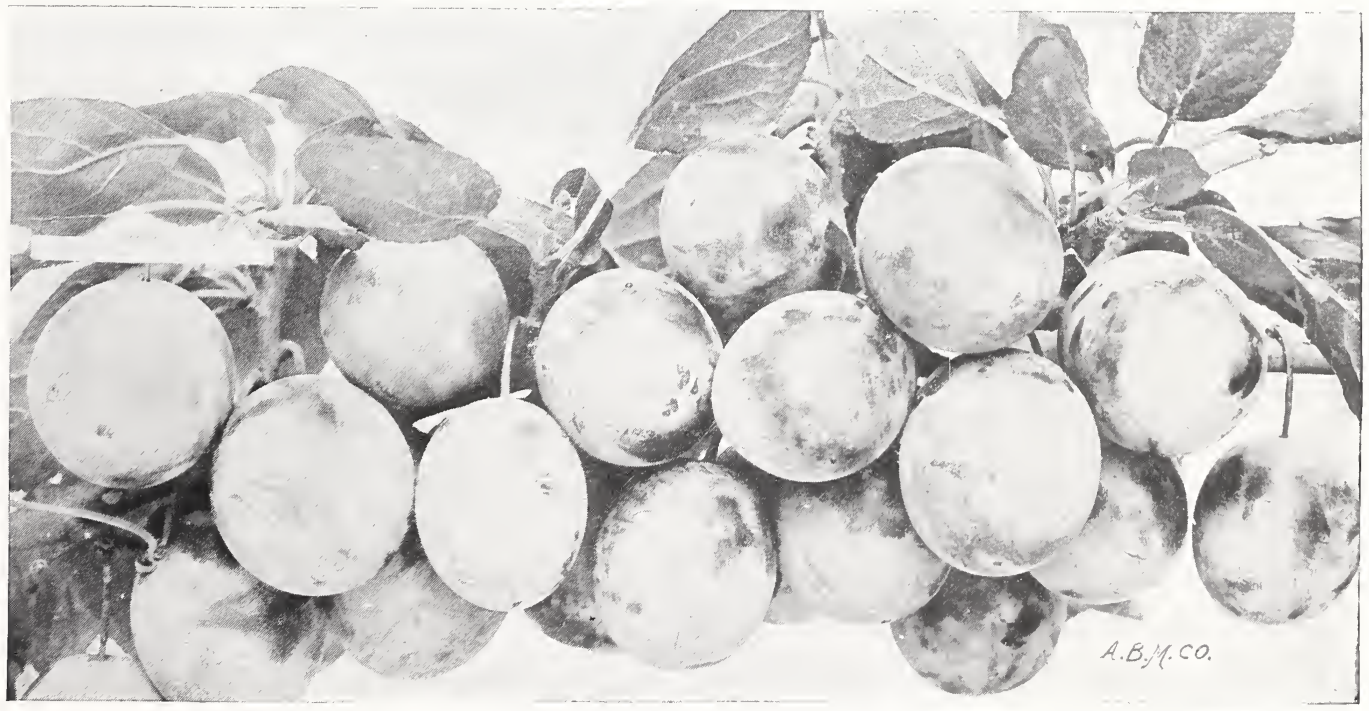




\section{Plums}

During the past few years there have been wonderful developments in the production of new varieties of Plums which have proven absolutely hardy in the Northwest. We are indebted to the Minnesota State Fruit Breeding Farm, Excelsior, Minnesota, for originating some of the most worthy of the newer rarieties. We now have hardy varieties of Plums to offer the planter of the Northwest, the fruit of which compares favorably with the large California Plums. We are now discarding many of the older varieties. called the Native or Americana, and are growing extensively the newer sorts which we have thoroughly tried and can recommend them to our many customers.

Elliot (Minnesota No. 8). Tree a strong grower and very hardy. Another variety which originated at the Minnesota Fruit Breeding Farm. In 1921 it ripened as far north as Winnipeg, Canada. This rariety is extremely productive and bears regularly; hence is a good late variety for home use or market. Ripening season about September 1st; fruit large, clingstone; pit small; quality good; color yellow overlaid with red.

La Crescent (Minnesota No. 109). Tree extremely vigorous, large, upright; fruit medium in size, slightly oval, clear yellow, sometimes with delicate blush; very tender, fine-grained flesh; juicy and sweet; semi-freestone; season very early.

Monitor (Minnesota No, 70). Tree unusually vigorous and produces a compact, well shaped head, very productive and hardy as far north as the Minnesota Fruit Breeding Farm. Fruit large, roundish, well colored with dark, dull red; stone medium, cling: quality good. Very promising as a market Plum.

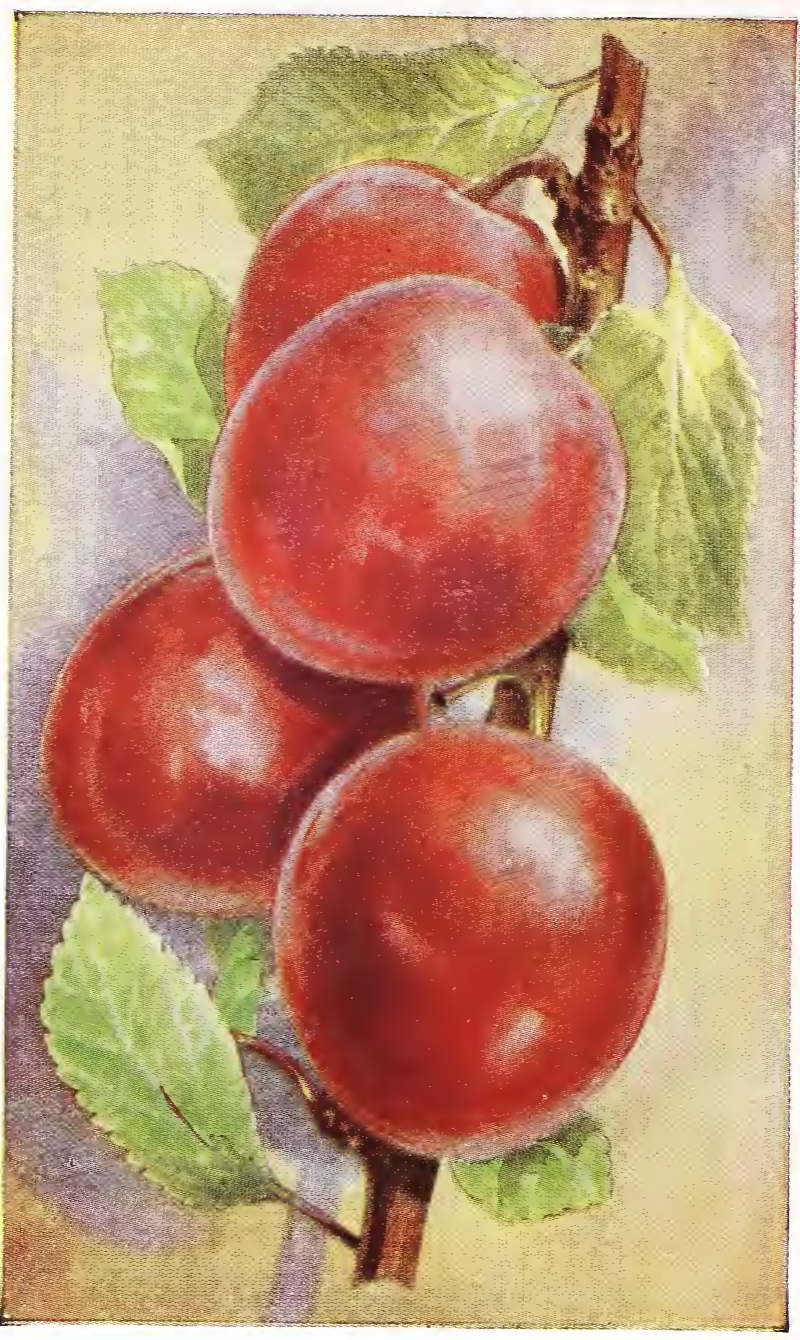

Loring Prize Plums.

\section{Loring Prize Plum}

ka (Minnesota No, 21). Very productive and hardy in the North. Originated at the Minnesota Fruit Breeding Farm, Excelsior, Minnesota. Fruit large, yellow, well overlaid with red; flesh firm; freestone when fully ripened; flavor sweet; quality good. Ripening season August 15th. Especially recommended as a market Plum of splendid keeping and shipping quality.

Underwood (Minnesota No, 91). Produces one of the strongest growing trees of hybrid Plums. It is entirely hardy at the Fruit Breeding Farm, and very promising because of its large, early fruit. Fruit attractive red, with fairly firm, juicy flesh, small pit; clingstone; hangs well and ripens over a long period. Season August 1st to 15th.

Winona (Minnesota No, 30). Tree vigorous but does not overgrow the stock. Top spreading and compact, and requires very little pruning; hardy and a regular bearer. Fruit large, with yellow background, turning red when ripe; roundish: pit semi-cling; juicy, sweet; quality very good.
To encourage and stimulate the growing of Plums and create a finer quality of fruit, the Hon. C. MI. Loring offered a prize for a Plum that would meet certain requirements including size, shape, color, flavor, smallness of pit, firmness and texture of flesh, together with general good characteristics of the tree. Such a Plum was originated at Lonsdale, Minnesota, a few years ago and is now known as the Loring Prize Plum, which, in spite of all coinpetitors, received the unanimous reward of the committee. It is the largest and best Plum for the northern planter today. It is a splendid fruit, good for canning, attractive color. The seed was the Burbank crossed with the DeSoto or Weaver Plum. The size is from $1 \frac{3 / 4}{4}$ to $23 / 4$ inches in diameter. It is slightly oblong, of bright color, fleshy, like the Burbank and nearly freestone, delicious in sweetness and mild in acidity. We consider it superior to the large red California Plum that we see in the fruit stores. delicious to eat, has small pit, is of a bright 


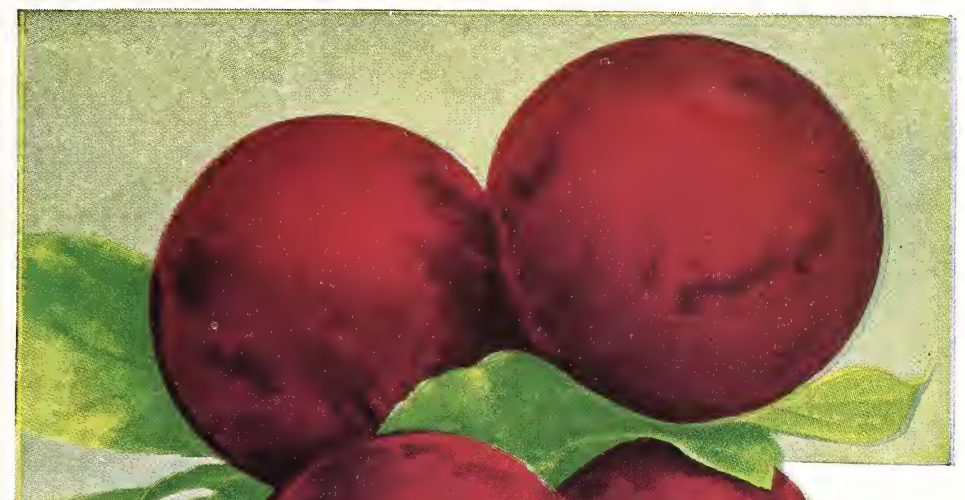

\section{Prof. Hansen's Hardy Plums}

Prof. Hansen has originated a number of improved American Plums. We say improved, because they have been thoroughly tested and found extremely valuable and desirable. They will grow on sandy or heavy soil. May be planted for ornamental effects as well as useful. Trees of this class are desirable from every standpoint and every home should be supplied with these varieties.

Kahinta. A cross between Burbank's Apple Plum and the Terry. It is a good fruiter and appears hardy throughout the North. Fruit large, firm, $1 \frac{3}{4}$ to 2 inches in diameter; color red; flesh firm, with small pit and delicious flavor.

Toka (Toka is the Indian word for Adversary). This is a cross between the Americana Plum and the fragrant Apricot of China. It resembles the Hanska in some respects and may be planted with it with good success. The tree is remarkably strong and vigorous. In growth it may be called a model tree. It bears early. The fruit is dark red in color, very handsome, firm, large and a good shipper.

Tokata. Another of Prof. Hansen's originations. Hardy, and produces fruit young. Tree of a spreading habit. Fruit red; similar to Toka in size. Delicious quality.

Waneta Plums.

Waneta. This wonderful large new Plum is the latest addition to Prof. Hansen's productions. Following is Prof. Hansen's own description: "My belief is that in this variety I have combined the best points of the native and Japanese Plums. It is probably the largest of the 10,000 seedlings. The size here at Brookings, S. Dak., in 1912, was two inches in diameter, weighing about two ounces." All reports indicate that the Waneta is everything that Prof. Hansen claims it to be. Its color is deep red, flavor is delicious. The tree is hardy and very prolific. Its size and quality, the hardiness of tree and great productiveness, are such that the demand will be great. May be planted with other Americana Plums or with Hansen Hybrids.

\section{Japan and European Plums}

These varieties are among those planted along Lake Michigan and in favored western localities. Wherever hardy they are desirable on account of their large size, but none of them are superior to the preceding native Plums in quality.

Abundance. Imported from Japan. One of the best Japanese Plums. Fruit medium to large; color bright red, almost entirely overlaying a yellow ground; flavor sweet and rich; quality good to very good. Early.

Arctic (Moore's Arctic). A well known variety and considerably planted where hardy. Fruit medium, roundish; color black with a thin blue bloom; flesh tender, juicy, yellowish amber, very sweet; pit small, oval, nearly free. Season medium.
Burbank. Imported from Japan in 1885 by Luther Burbank. Fruit conical, large to very large; color dark metallic red on yellowish ground; skin medium; flesh yellow, firm, juicy; flavor rich and sugary. Tree very strong, wayward grower and requires frequent pruning.

German Prume. One of the very oldest varieties known, having been grown in Europe before the beginning of horticultural history. Fruit long, oval, small to medium; color blue; flesh greenish, slightly yellow; stone small, oval, pointed, very free; quality fair to good.

Lombard. Fruit oval, medium to large; color delicate purplish or reddish violet with blue bloom; flesh yellow, firm, of fair quality; stone cling. Season medium to early.

Yellow Egg. Fruit in shape like a goose egg; size largest; with long stem; color creamy yellow when ripe, white bloom; flesh yellow; quality fair. Season medium. 


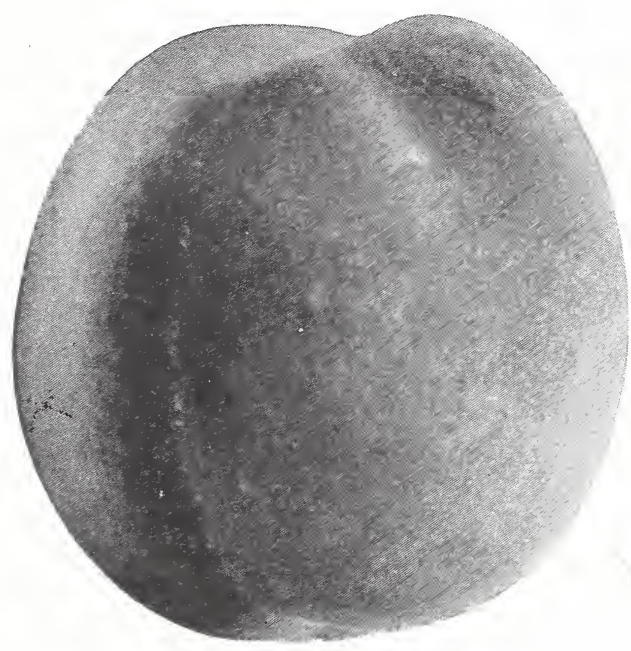

Marquette Peach.

\section{Quinces}

Quince trees should be planted in rich, deep, moist but well drained clay soil. We do not recommend planting of Quinces in Wisconsin.

Orange. Large; roundish, with a short neck; bright golden yellow; very proauctive.

\section{Mulberry Trees}

These are sometimes classed among ornamental trees on account of their fine foliage and form. For the North, the Russian variety is the only one that should be planted.

Downing's Everbearing. One of the most prolific varieties, with large, black, sub-acid fruits. Its long bearing season has made it a universal favorite.

Russian Mulberry. Introduced to this country by Russian Mennonites and on account of its hardiness and ornamental appearance has been considerably planted throughout the West. The fruit is highly prized by the birds and it performs a valuable service by keeping them away from the garden.

\section{Nut Trees}

These trees are not only useful for shade and ornamental purposes, but bear an abundance of nuts which are very profitable. The growing demand for nuts is giving quite an impetus to the planting of nut trees. Many farms contain land that would be far better planted to nuts than anything else, and would pay better than farm crops, besides annually growing more valuable as timber

Butteruut. Sometimes called White Walnut. The tree greatly resembles the American Black Walnut, to which it is closely allied. The nuts are elongated, more oily than the walnut and less pronounced in flavor. some consider the quality superior. Yields well and is perfectly hardy. Grows twenty to forty feet.

Walnut, Black. A native tree of large size and majestic form, beautiful foliage. The most valuable of all trees for its timber, which enters largely into the manufacture of fine furniture and cabinet ware, and brings the highest price in the market. Tree a rapid grower, producing a large, round nut of excellent quality. Grows 30 to 40 feet.

\section{Peaches}

Peach trees are not considered very hardy in Wisconsin; however, we have found favored locations where they have done well. The following are among the leading varieties, all of which are freestone. We can supply varieties in addition to those listed herein.

Champiou. Fruit is usually large, some specimens measuring ten inches: fruit rich, sweet, juicy, beautiful color; creamy white and crimson. A good shipper. August.

Crawford's Early. A magnificent, large, yellow Peach; its size, beauty and productiveness make it a popular variety. August and Sept.

Elberta. A leading market variety that thrives and is productive in all Peach srowing sections; fruit large, bright yellow, overspread with crimson; flesh juicy and of good quality. August and September.

Marquette. Originated as a chance seedling in Marquette County, in the northern peninsula of Michigan. Medium sized, white fleshed, freestone Peach of excellent quality; fine flavor and a nice eating Peach. Not suitable for long distance shipping. We received our propagating wood from the Michigan Agricultural College; therefore, we have the pure Marquette Peach. There is no question about it being unusually hardy.

\section{Apricots}

The Russian varieties listed below are much hardier than other sorts. These have stood twenty degrees below zero without injury and are very desirable in favored parts of the Northwest.

Alexis (Russian). Large to very large; color yellow with red cheek; flesh rich and luscious, slightly acid. July 15 th.

Budd (Russian). Large size, color white with red cheek; flesh sweet, juicy, extra fine; best late variety. August 1st.

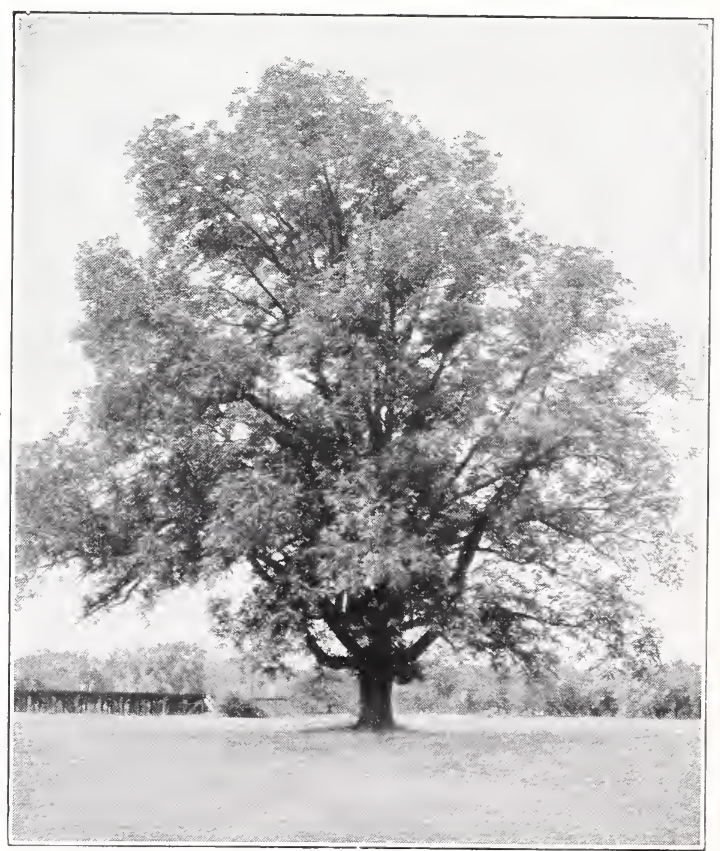

Black Walnut. 


\section{Asparagus}

Prepare the ground by spading to the depth of 15 inches, mixing each layer of soil as turned over, with two or three inches of well-rotted manure. For private use or for marketing on a small scale, beds should be formed five feed wide, with three rows planted in each; one in the middle and one on each side, a foot from the edge; the distance of the plants in rows, nine inches; the alleys between the beds should be two feet wide. In planting a line is set and a cut made, a little slanting, to the depth of six or eight inches, according to the size of the plant. The plants are then laid against the side of the trench, at the distance already siated, care being taken to properly spread the roots. The crown or top of the plant should be covered about two inches. In a week or so after planting, the beds should be touched over lightly with a sharp steel rake, which will destroy the germinating weeds.

The Asparagus bed is very apt to be neglected in the early Fall. Before the first of September the tops should be cut, and the bed or field cleared of weeds. It is highly important that all the seed should be taken off, as the greatest enemy the Asparagus has in the way of weeds is Asparagus, and it is almost impossible to get clear of superfluous plants when once established. When this work is finished, cover the bed to the depth of three inches with coarse manure, which will not only enrich the soil, but will keep out the frost, which is highly essential. The first work in the Spring should be to remove all the covering except the fine manure, which should be carefully forked in, so that the crowns will not be injured by the tines of the fork. Forking the beds should not be neglected, as the early admission of the sun and rain into the ground induces
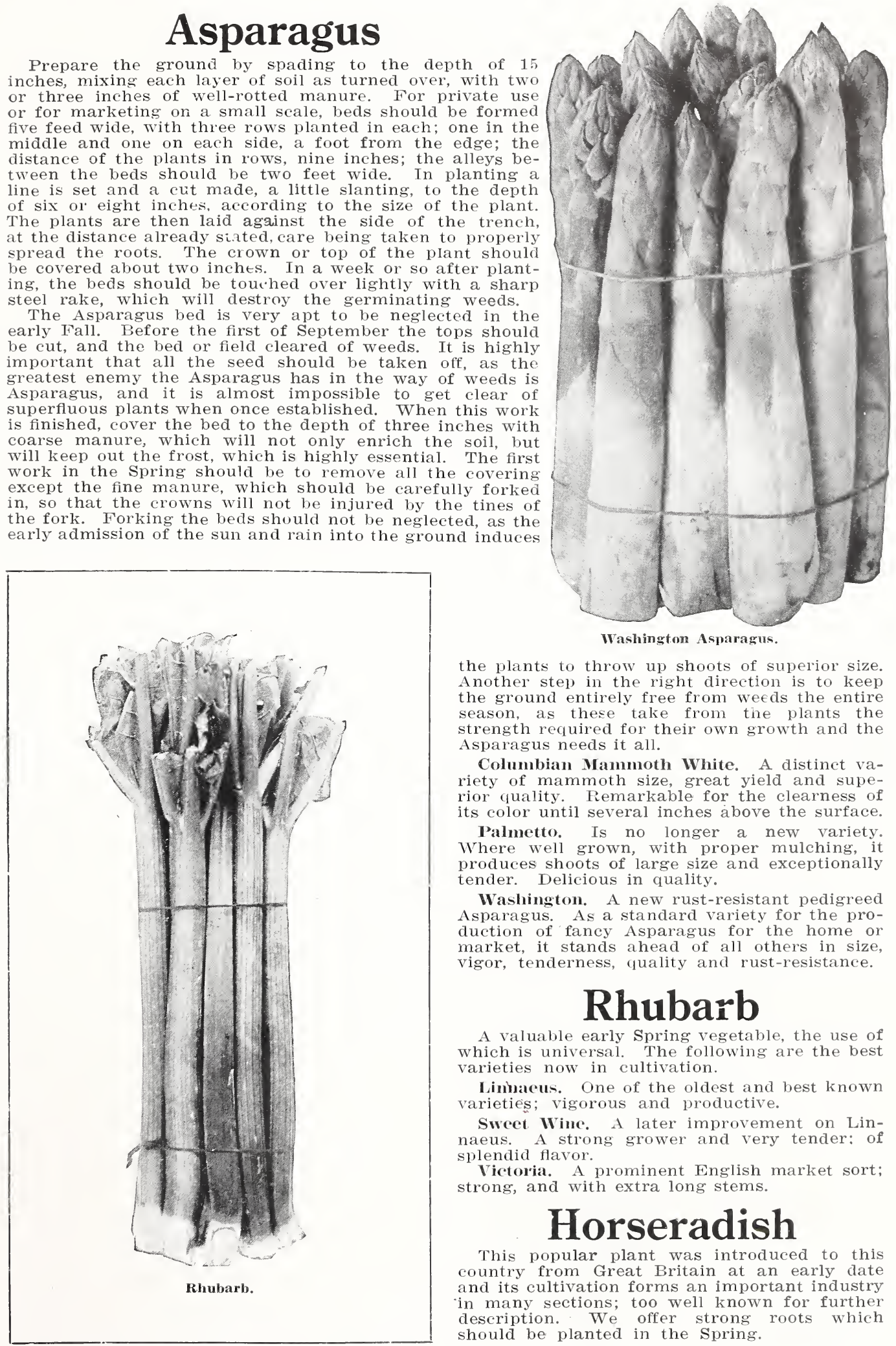

the plants to throw up shoots of superior size. Another step in the right direction is to keep the ground entirely free from weeds the entire season, as these take from the plants the strength required for their own growth and the Asparagus needs it all.

Columbian Mammoth White. A distinct variety of mammoth size, great yield and superior quality. Remarkable for the clearness of its color until several inches above the surface.

P'almetto. Is no longer a new variety. Where well grown, with proper mulching, it produces shoots of large size and exceptionally tender. Delicious in quality.

Washington. A new rust-resistant pedigreed Asparagus. As a standard variety for the production of fancy Asparagus for the home or market, it stands ahead of all others in size, vigor, tenderness, quality and rust-resistance.

\section{Rhubarb}

A valuable early Spring vegetable, the use of which is universal. The following are the best varieties now in cultivation.

Linmacus. One of the oldest and best known varieties; vigorous and productive.

Sweet Wine. A later improvement on Linnaeus. A strong grower and very tender: of splendid flavor.

Victoria. A prominent English market sort; strong, and with extra long stems.

\section{Horseradish}

This popular plant was introduced to this country from Great Britain at an early date and its cultivation forms an important industry in many sections; too well known for further description. We offer strong roots which should be planted in the Spring. 


\section{Gooseberries}

The Gooseberry, like the currant, is a favorite in the northern fruit garden. Gooseberries are grown with but very little care. All they require is some attention to fertilizing and cultivation, with an occasional spraying. The interest and demand for this fruit is constantly growing. An acre will produce from $\$ 800$ to $\$ 1000$ annually.

Carrie. Originated in Minnesota. Fruit red. After the third year, bush loses its thorns; very heary bearer, medium size; excellent quality.

Downing. A seedling of Houghton. Large and handsome, pale green berry; of splendid quality for dessert or cooking. Bush vigorous and exceedingly productive. An excellent sort for family use and most profitable for market.

Houghton. Enormously productive and always reliable. Of vigorous growth, slender and spreading; not subject to mildew. Fruit of medium size, smooth, pale red, tender and of good quality

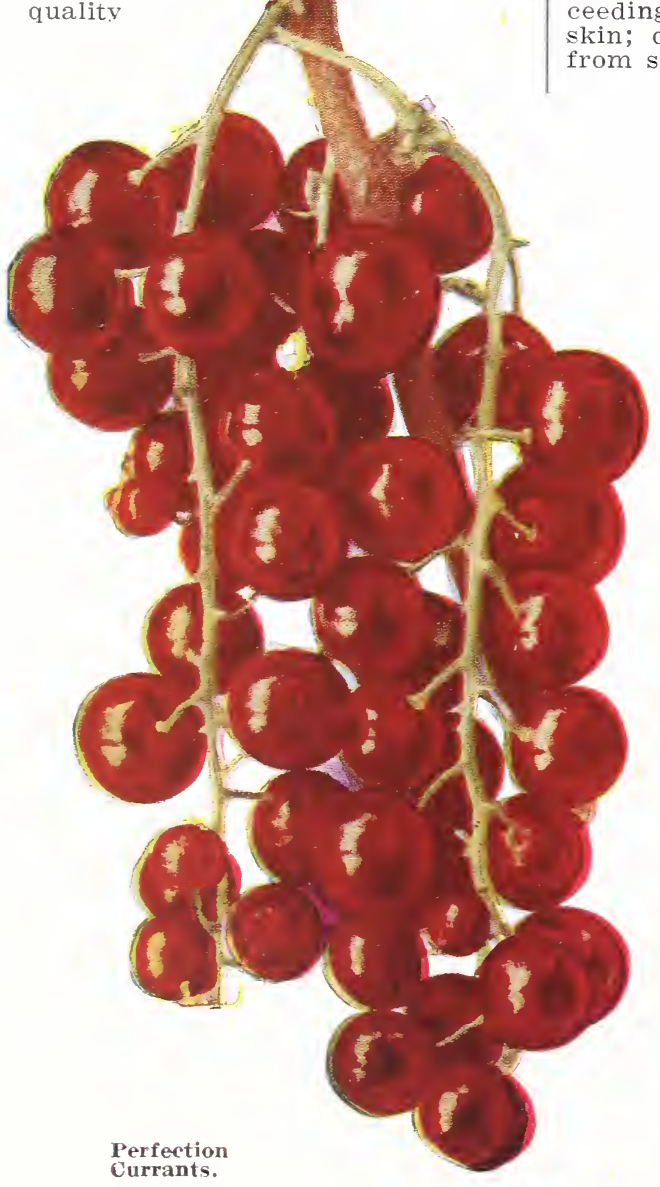

Pearl. Similar to Downing, but fruit generally reported much larger. Said to be a cross between an English and American variety. Very hardy; free from mildew and productive, even more so than Downing. Superior in size and quality.

Red Jacket (Josselyn). Bush is very hardy; clean, healthy foliage; vigorous and entirely free from mildew. Fruit large, smooth, red and of first class flavor and quality.

Snith's Improved. Bush moderately vigorous and exceedingly productive. Fruit large, pale yellow, thin of in; of excellent quality for dessert or cooking. Grown rom seed of Houghton. A valuable variety.

\section{Currants}

The Currant is an indispensable garden fruit. It is very largely planted all over the North, and owing to its early ripening season it is grown successfully as a commercial fruit in all sections. An acre of Currants properly cared for will produce from $\$ 1,000$ to $\$ 1,200$ worth of fruit annually. Currants are more easily handled than other small fruits, as they hang on the bushes from ten days to two weeks after they become ripe, without injury.

Cherry. Bush vigorous, stocky and compact; cluster rather short, fruit medium large; color bright red; very thin skin; juicy and fine flavor: one of the most productive.

Fay's Prolific. Berry averages large, juicy and less acid than Cherry; bush not quite so strong a srower.

London Market, Bush vigorous, upright; fruit medium to large; color dark red, with sprightly acid flavor; very productive.

Perfection. The latest introduction, being a. cross between Fay's Prolific and White Grape. combining the best qualities of both. Berry bright red and large. The clusters average longer and the size of berry is maintained to the end of bunch. In quality it is said to be superior to anything in the market today, being of a rich, mild sub-acid flavor with plenty of plup and few seeds.

Red Cross. One of the later introductions. A strong growing variety with long clusters. Berry medium to large, bright red. Of mild and pleasant quality and fine flavor.

White Grape. Bush vigorous, somewhat spreading, productive; clusters long; berries large; of very attractive color, mild flavor and good quality: a good table variety.

Wilder. A remarkable variety. One of the best grown. Very productive; bunches and berries large; splendid quality. Superior in every way to the common sorts. Should be largely planted for home and commercial purposes. 


\section{Select Hardy Grapes}

Everyone should have Grape vines in the home garden. They require very little cultivation and the returns are so abundant. If proper selection of rarieties is made, one may have Grapes on the table for several months in the year. They can be trained over fences, trellises or doorways, and thus be ornamental as well as useful. To grow for market, they can be planted on hillsides that are unsuitable for other crops. They should in all cases have a free exposure to the sun and air.

The vineyard should be top-dressed with well-decomposed manure or ground bone; slacked lime ashes every third or fourth year is also beneficial. To secure the best results, annual and careful pruning is essential. Commencing with a strong, two-year-old vine, such as we furnish, at time of planting cut back to within three or four buds of the roots. In November or December-as soon as the wood is thoroughly ripe-cut back the growth nearly to the ground, allowing but three or four buds to remain. Never prune close to the bud, but leave an inch or two of wood beyond. The following Spring allow but two of these buds to throw out shoots; these will be from seven to ten feet in the Fall, and should then be cut back to four or five feet. The next Spring these two shoots should be fastened horizontally to the lower part of the trellis. When growth commences, allow only such buds to grow as will leave the upright from ten to twelve inches apart; as these grow, train them perpendicularly to the upper bars of the trellis. They should be allowed to bear but little this year, as an over crop will injure the health of the vine. When the shoots have reached the upper part of the trellis they should be pinched to prevent further growth.

Agawam (Red). Bunch large, compact, shouldered; berry large, dark red, or nearly black; flesh tender, juicy, vinous and good quality; later than Concord.

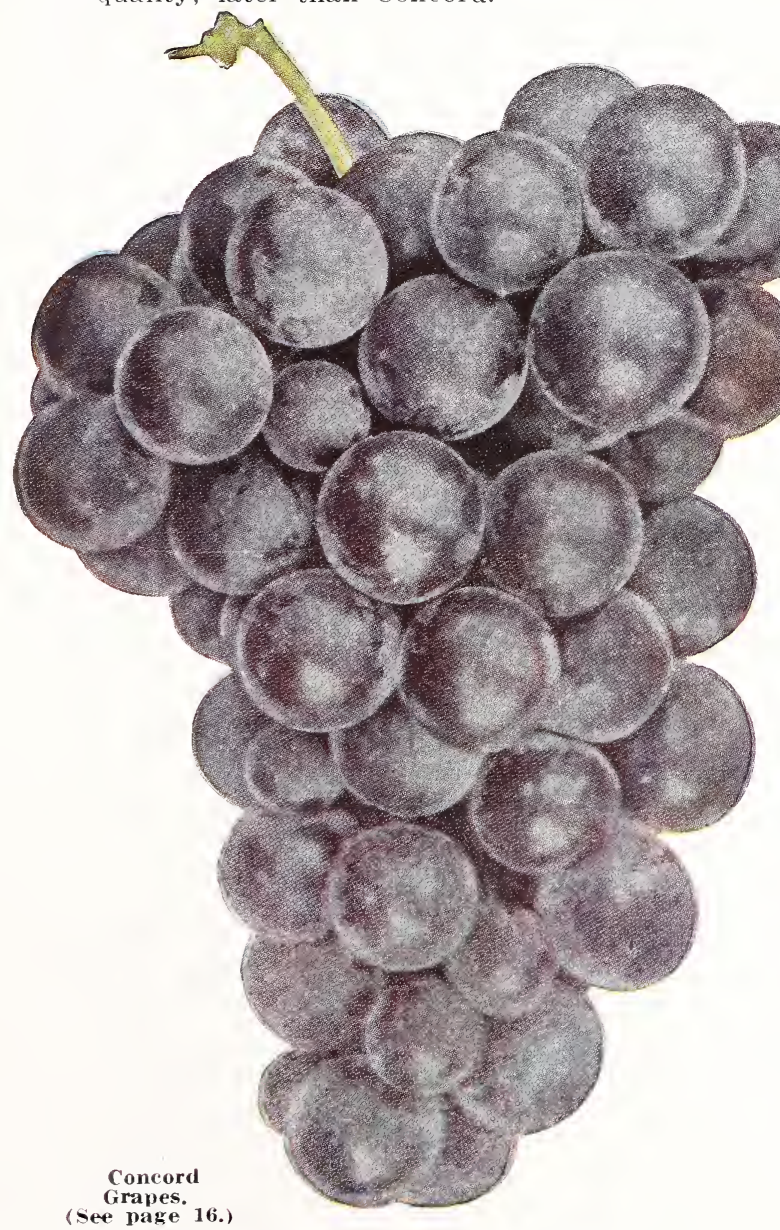

Alpha. The native vine was found growing wild in woods belonging to St. Johns University, Colle ge ville,

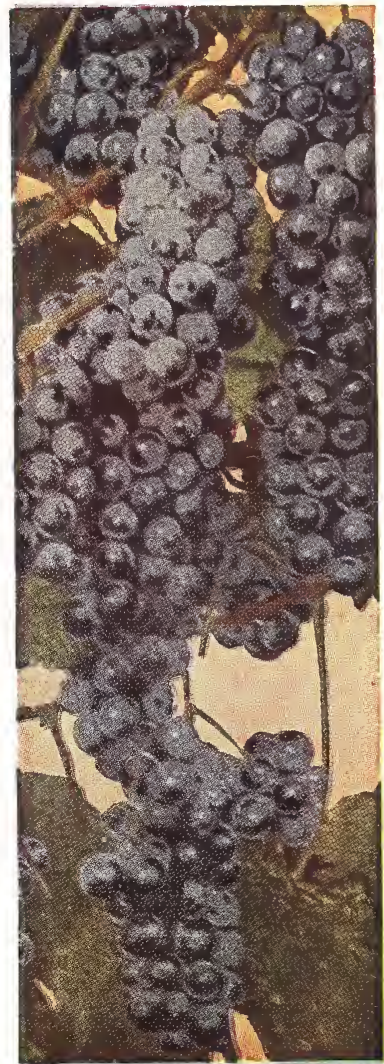

Alpha Grapes.

Minn e sota.

The Alpha developed into a healthy, vigorous vine, free from mildew, bearing bunches of large size and good quality The Alpha has endured the severe climate at Collegeville without any protection for the past eighteen years. When wood has well ripened, thirty degrees below zero will not injure the vine. The Alpha is not a table Grape but is very valuable for making grape juice, jellies, etc. Further, it is extremely valuable for covering arbors and trellises on account of its extreme hardiness and very rapid growth.

Beta. A cross between Carver and Concord; perfectly hardy, productive; fruit of medium size; early. The principal value of this Grape is in the extreme North where it will stand without protection.

Brighton (Red). Bunch medium to large, quite compact; flesh rich, sweet and best quality; color dark crimson or brownish red; vine vigorous and hardy.

Caco. A new variety originating in Delaware and widely heralded as the very best red Grape known. Its name is a combination of Catawba and Concord from which two standard sorts it was derived. Caco seems to have overcome the few defects in either parent, exemplifying all of their strongest virtues; thus presenting an individuality without precedent in Grape culture. The vines are strong and vigorous, as yet untouched by disease of any kind. The fruit is very large and handsome, complete bunches; in color a rich wine-red over amber. Exceptionally early bearing, usually showing several good-sized bunches the second year. Its flavor is luscious, sweet, delightful, distinctive. 


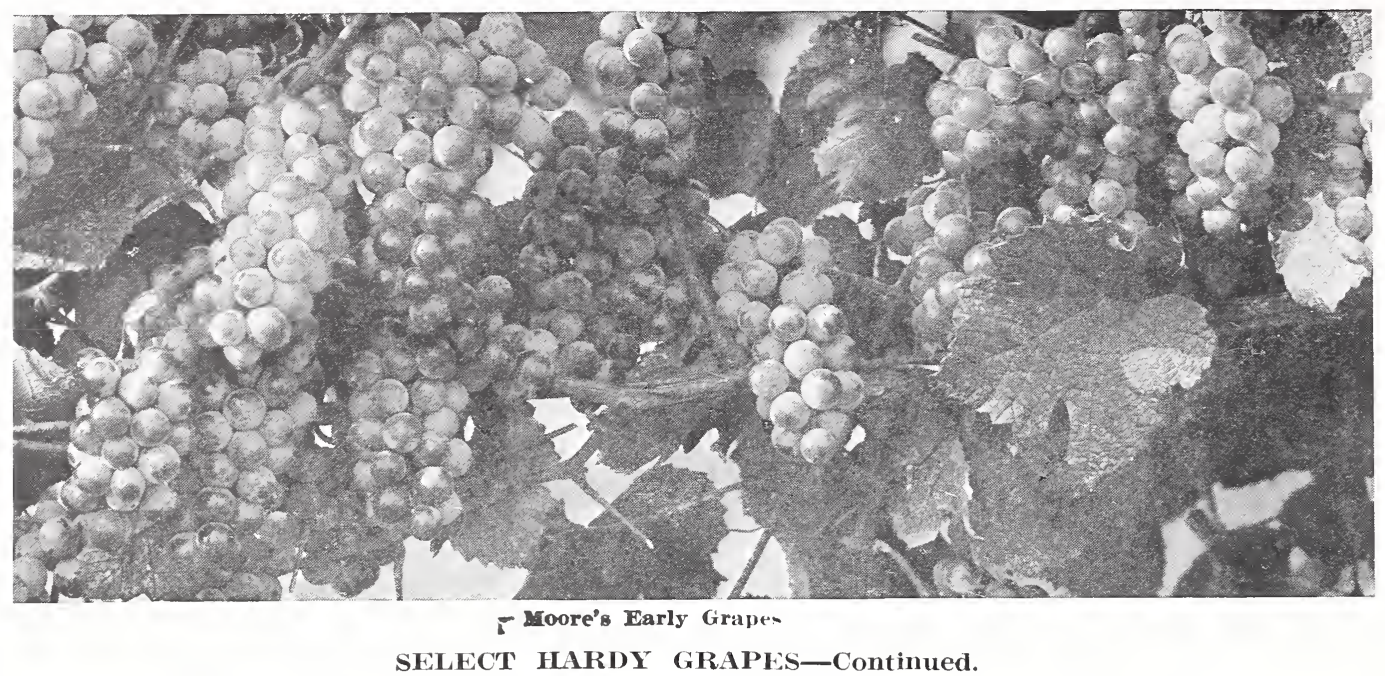

Campbell's Early (Black). The king of American Grapes; a very strong, vigorous, hardy vine, with thick, healthy, mildew-resisting foliage and self-fertilizing blossoms; always sets its fruit well, and bears abundantly.

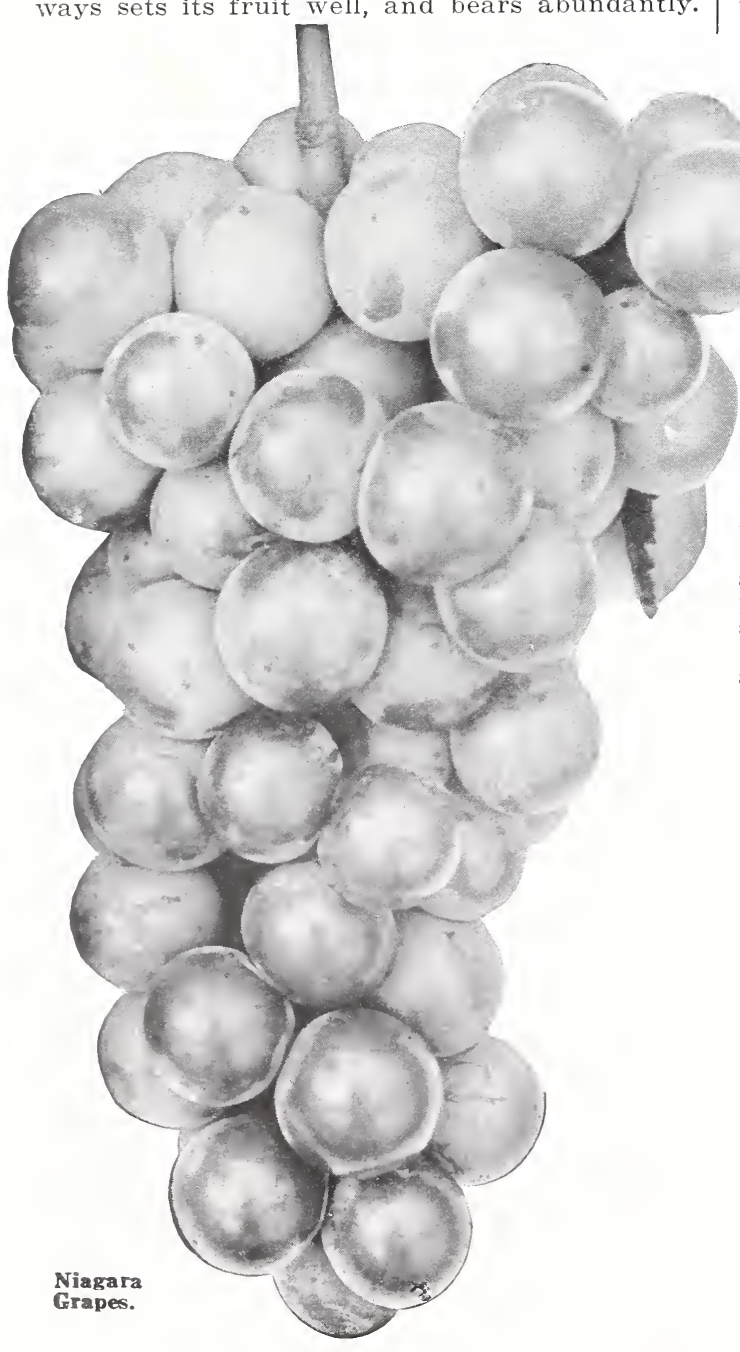

Concord (Black). (See color engraving on page 15). Too well known to need much description; is considered by many to be the best all around Grape grown. Is extremely hardy, vigorous and productive; bunches large, corrpact.

Delaware (Red). One of the best red Grapes; bunch small and compact; berry small, round, beautiful light red; flesh rich, rinous, sweet and delicious; best quality; a good market Grape.

Hungarian. Originated in Minnesota. Very productive, with small, compact bunches; fine flavor: fruit black. Very suitable for arbors and needs no Winter protection. Extremely valuable for making grape juice.

Moore's Early (Black). Bunch large, berry round with a heary blue bloom; quality said to be better than Concord; hardy and prolific; a good market berry; ripens about two weeks before Concord.

Niagara. This white Grape has attracted the most attention of any new fruit recently introduced. The vine is a strong grower, healthy and prolific: bunches large, uniform and compact; berry large, skin greenish white, slightly ambered in the sun; quality rood. Ripens with Concord. Skin tough, making it a good shipper and market Grape.

Pocklington (White) Vine very vigorous and hardy: berry a light lemon-yellow. tender, sweet and fine aromatic flavor; very prolific.

Salem (Red). Bunches and berries large, coppery red; flesh tender, juicy, with slight pulp, of the very best quality; vine vigorous and fruitful. Ripens with Concord.

Worden (Black). Said to be a seedling of the Concord, and is a slight improvement on that variety; ripens a few days earlier; bunch large and compact.

We have the most modern and up-todate facilities in the Northwest for the proper handling of Nursery Stock. As soon as dug all stock is hauled immediately into packing building, where it is carefully graded. Every order is selected and packed under cover and loaded directly into cars. 


\section{Blackberries}

The Blackberry is a native fruit in all the northern states. The following cultivated varieties are recommended. It is one of the hardiest garden fruits in the catalog.

Incient Briton. A reliable market variety of medium size and of best quality. One of the hardiest. Berries large and sweet. Sells well on the market and is a very profitable variety.

Blower. The largest of the Blackberry fam. ily. Plant is upright and hardy. One of the most productive, a single plant producing over two thousand berries. Jet black. A good shipper. Ripens about July 15 th and continues for six weeks.

Eldorado. Of late introduction, being vigorous and hardy in most localities. The berries are large, coal black, flavor sweet and melting and have no hard core. Very firm and therefore an excellent market variety.

Snyder. Medium size, no hard, sour core, half as many thorns as some other varieties, and they are nearly straight and short; extremely hardy, enormously productive. Ripens in good season.

Lucretia Dewberry. A variety of the lowbush or running Blackberry, ripening before black raspberries are gone. Fruit large, jet black, and very showy, often measuring from 1 to $1 \frac{1 / 2}{2}$ inches in length.

\section{Raspberries}

This fruit should be grown by every real estate owner. It succeeds best in a moderately rich, mellow soil. Should be planted in rows five or six feet apart, leaving the plants about four feet apart in the rows. They require good cultivation and that the ground be kept clear of weeds. Most of the suckers should be cut away to throw the strength into the stock for bearing. All the old canes should be removed immediately after the bearing season is over.

Columbian (Purple). The Columbian is a seedling of the Cuthbert, grown near the Gregg Blackcap Raspberry, and believed to be a cross between the two. It is a most vigorous

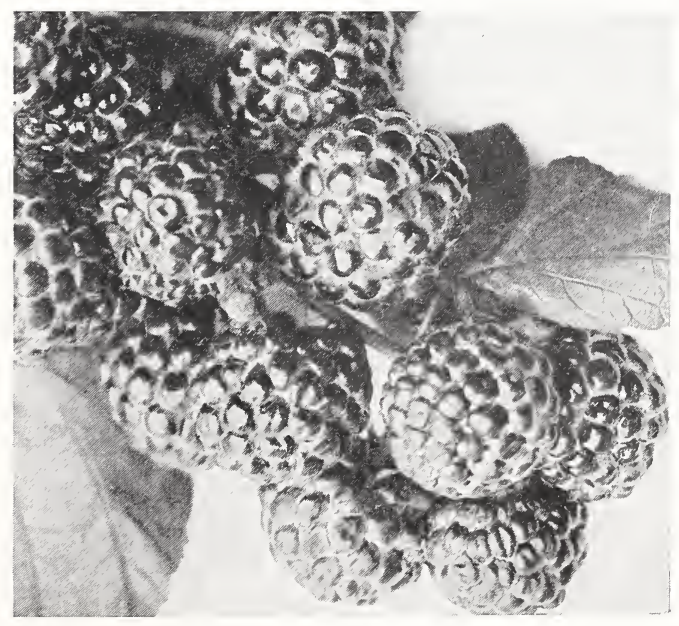

Kansas Raspberries.

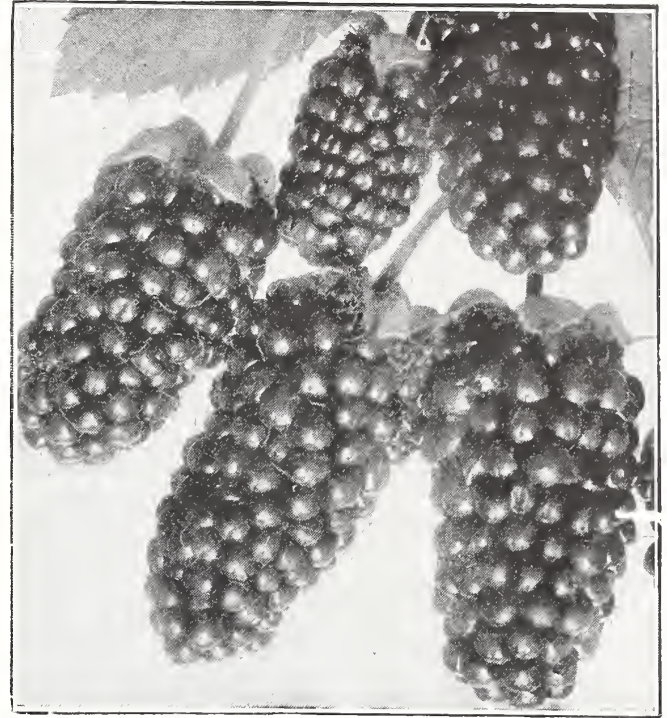

Ancient Briton Blackberries.

grower, canes 10 to 16 feet in length and often over an inch in diameter; fruit very large; color dark red bordering on purple; adhere firmly to the stem; seeds small; has a distinet flavor of its own, making it a most delicious table berry. For canning purposes it is much superior to any other.

Cumberland (Black). "The Business Blackcap." It is of wonderful productiveness, producing regularly and uniformly very large crops. In size the fruit is simply enormous; far surpassing any other variety. The berries run seven-eighths and fifteen-sixteenths of an inch in diameter.

Cuthbert (Red). A strong grower and very productive; large, bright red, fruit firm, of very fine quality. Season medium to late; a good one for market or home use. It is doing well everywhere.

Golden Queen (Yellow). One of the best yellow varieties grown.

Grego (Black). Of good size, fine quality, productive and hardy, firm, sweet and rich, strong grower and good bearer; ripens late and evenly; good market berry.

Kansas (Black). Large, round, firm, moderately juicy, strong grower and very productive, ripens early; consideled one of the hest market berries on account of its handsome appearance.

King (Red). Many of our leading fruit growers consider this one of the best of the early Red Raspberries. Berries large and attractive, bright red in color and of good flavor. Ripens with the earliest and is firm enough to ship well. The canes are healthy and productive. Very hardy.

Touden (Red). This variety is a marvel of productiveness and hardy to the tips of its shoots. Its large and beautiful, rich, dark crimson fruits are of good flavor, ship better and hang longer after ripening than those of any other variety. Ripens midseason.

Marlboro (Red). The largest early red; bright scarlet, sub-acid, pleasant and good: hardy and productive. 


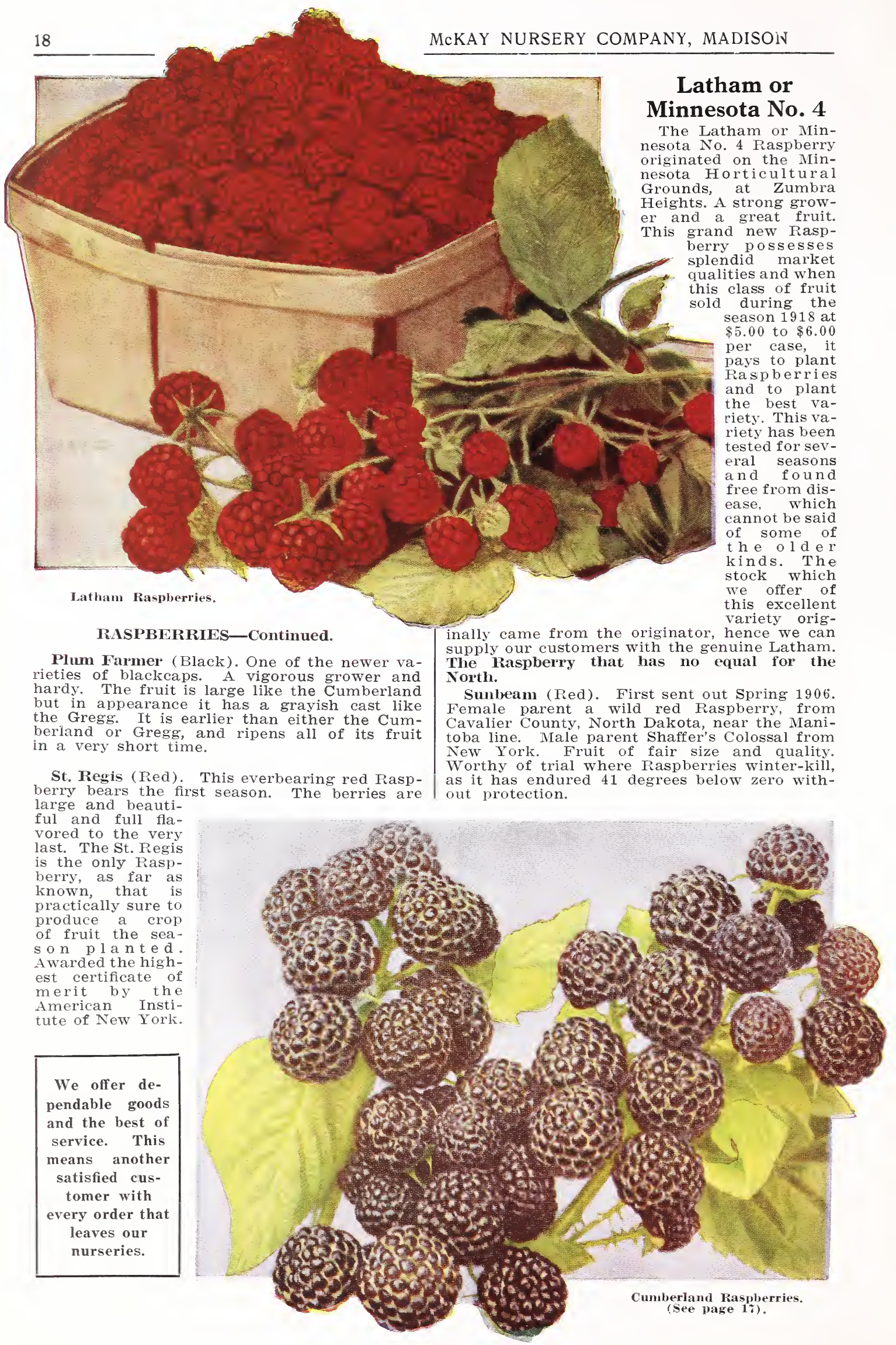




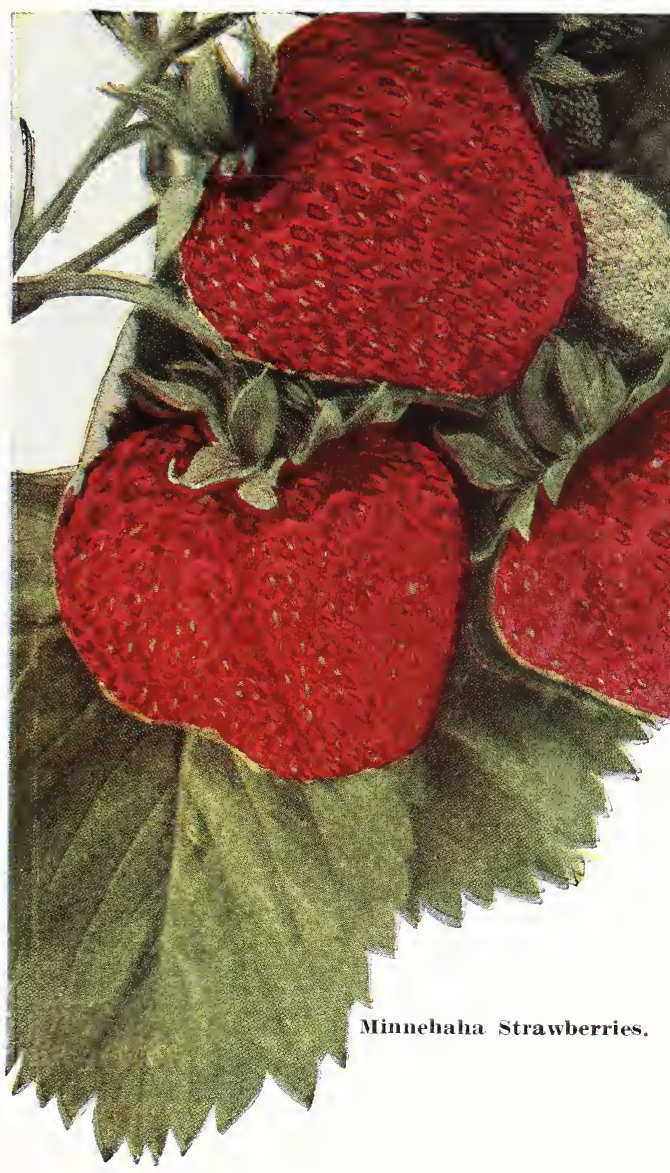

\section{Fall or Everbearing Strawberries}

What lingering doubts may have been felt as to the practical value of this new race of Strawberries are rapidly vanishing in the light of experience. There is now scarcely a discordant note in the general praise of their qualities for the home garden, and the developments of the present season indicate a greater value for the market garden than had before seemed probable. They have been on trial over a wide territory for several years and have been found extremely hardy, foliage perfectly healthy, a good crop producer of excellent quality, fruiting exceptionally early and continuing to fruit until checked by severe frosts. The blossoms should be picked off from newly set plants until they are well established.

Americus (Per.) This is one of the most thrifty growers of any of the Fall-bearing varieties. It does not seem to be affected by the Fall crop of fruit produced, and comes out in the spring looking as fresh and vigorous as a June-bearing sort. The fruit is from medium to large in size, conical in shape, rich red in color and of a delicious flavor.

Progressive (Per.) One of Mr. Rockhill's productions. A good plant maker, strong, with healthy foliage. Bears a crop the same season set. Fruit large, sweet and of the choicest flavor. Plant it and you will have berries from June until November.

\section{Strawberries}

The Strawberry is perhaps the most popular small fruit cultivated in the North. As is well known, many of our best varieties of Strawberries have imperfect or sterile blossoms. For this reason, when planting such varieties, it is necessary to alternate them with staminate or perfect varieties in order that the blossoms may become fertilized. In the following list, the buyer will therefore find such varieties designated as either perfect or imperfect. In our list we have aimed to include those varieties that by actual test have proven the most valuable in average locations.

Aroma (Per.) Plant shows no weakness of any kind. Fruit very large, roundish conical, rarely mis-shapen, glossy red, of excellent quality and produced in abundance. One of the most profitable late varieties that we grow. It produces twice as much as Gandy, and fine berries.

Dr. Burrill (Per.) (The Million Dollar Strawberry-The Gem of Perfection). This variety was originated by Dr. Reasoner, of Illinois, and is a cross between Dunlap and Crescent. A big cropper. Berries large, dark red, of the best quality, and uniform in size and shape. This new variety is a strong fertilizer; its season of blossoming and fruiting extra long.

Easypicker (Minnesota No. 775). (Imp.) A very productive hardy variety unusually easy to pick. Foliage moderately heavy, leaves large Flowers imperfect. Fruit large, regular, nearly round; color medium red; flesh dark red throughout, fairly firm, sweet, mild, very good. A good market berry, ships well and its size holds large throughout the season. Ripens in midseason.

Gibson (Per.) A new variety of merit. Bears with Dunlap and Warfield, but owing to its productiveness, continues till quite late. Strong grower. Berry large, glossy red, good quality.

Mimmehaha (Minnesota No. 935). (Per.) Foliage very heavy; leaves large, dark green; perfect-flowering; fruit very large, slightly irregular; dull, medium red; flesh light red, juicy, firm; quality good. Ripens after the Dunlap.

Premier (Per.) A prize winner and money maker. A strong growing, early variety adapted to all soils and climates. A bed of this variety should prove exceptionally satisfactory.

Senator Dunlap (Per.) A variety of great merit, and much admired. Fruit of large size, regular and attractive in form, deep red in color, firm and excellent in quality; season early and continues in bearing nearly a month. Plant somewhat resembles Warfield.

Stevens' Late Champion (Per.) Makes strong, vigorous plants which produce an abundance of fruit. The plants send out many runners that take root quickly and cover the ground if not restricted. Fruit large, long, slightly flattened. Color deep red, flesh also red.

Warfield (Imp.) The Warfield is a large, beautifully shaped berry, with glossy dark red exterior that does not fade or become dull after picking. This characteristic is continued even after it is canned, which is one reason for its great popularity. The flesh is a rich, dark red clear to its center; it is very juicy and just tart enough to give it a fine relish. 


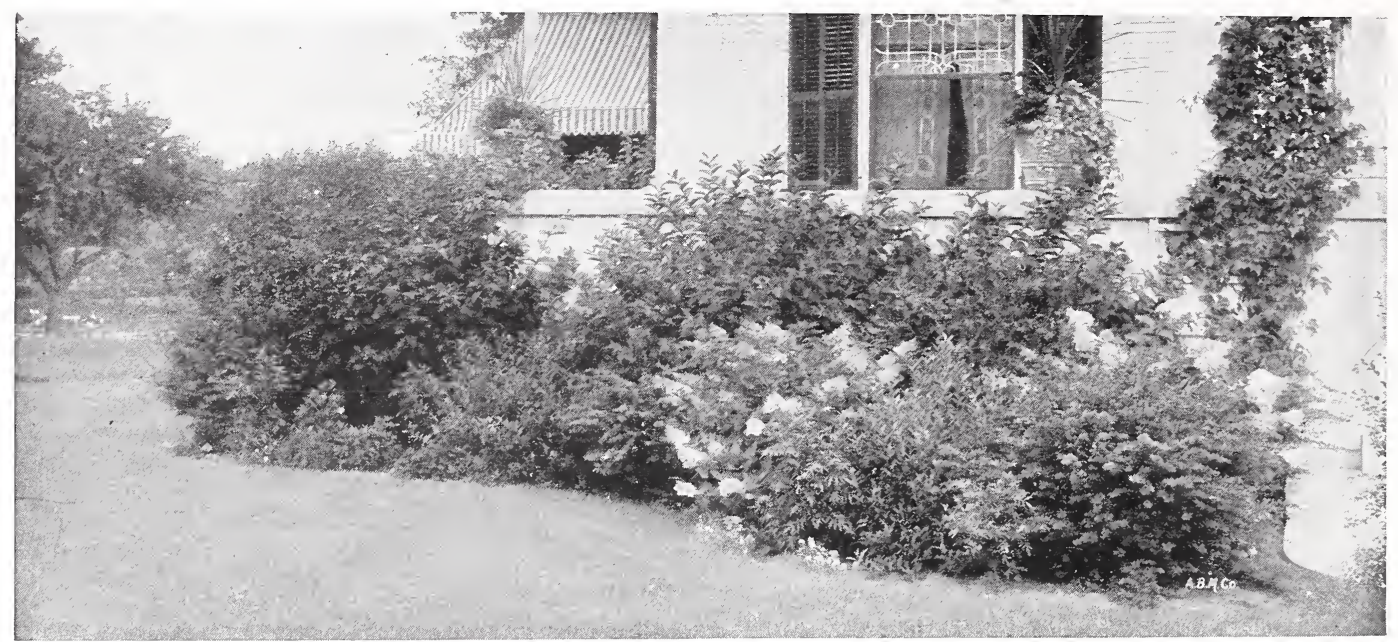

An Attractive Base Planting of Shrubbery.

\section{Ornamental Department}

A great many people are beginning to realize that by expending a little time and study they can have well-kept and attractive grounds, adding to the beauty and comfort of the home and increasing the value of the property.

\section{Brief Suggestions to Planters}

Each variety is described from the standpoint of its habits. As to height, we have adopted the following broad classification, which will give a fair idea of the comparative size of species listed:

Lg. Trees usually attaining a height of fifty feet or more at maturity.

Med. Trees usually less than fifty feet and more than twenty-five feet at maturity.

Sm. Trees commonly less than twenty-five feet at maturity.

What to Plant. In this and similar climates, where great extremes of temperature are experienced, it is necessary to employ only the most hardy ornamental trees and shrubs. Impressed with the importance of this fact, and in order that our customers may be spared much disappointment and expense, we have omitted, as far as possible, everything which is liable to suffer from severe cold.

Preparation of the Roots. Cut off smoothly all bruised or broken roots up to the sound wood. This prevents their decaying and hastens the emission of new roots and fibres.

Preparation of the Top. This consists in cutting back the top and side branches in such a way as to correspond with the more or less mutilated roots as follows: Trees with branching heads should have the small branches cut clean out, and the larger ones, intended for the framework of the tree, cut back to within two or three buds of their base.

In cases where there is an abundant root and small top or few branches, the pruning need be very light, but where the roots are small and the top heavy, severe pruning will be necessary. These remarks are applicable to all deciduous trees and shrubs. Evergreens seldom recuire pruning, but Arbor-Vitae and other Evergreens planted in hedge rows may be shorn immediately after planting.

Pruming. Pruning has the effect of rendering trees and shrubs unnatural and inelegant. Wé refer to the custom of shearing trees, particularly conifers, into cones, pyramids and other unnatural shapes. Every tree, shrub and plant has a habit of growth peculiar to itself, and this very peculiarity is one of its beauties. If we prune all trees into regular shapes we destroy their identity. The pruning knife should be used to assist Nature, and operated with good judgment; to lop off straggling branches, to thin the head of a tree which has become too dense, and to remove dead wood.

Each shrub has peculiarities of habit and foliage, and we should aim to preserve them as far as possible. Judicious pruning to secure health and vigor is necessary, but trimming all kinds of shrubs into one form shows lack of appreciation for natural beauty, to say the least. Weigelas, Deutzias, Forsythias and Mock Orange flower on the wood of the preceding year's growth, hence the shrubs should not be pruned in Winter or Spring, but in June, after they have finished flowering, when the old wood should be shortened or cut out, thus promoting the growth of the young wood, which is to flower the following season.

Spireas, Lilacs, Altheas and Honeysuckles may be trimmed during the Winter or early in Spring, but the branches should only be reduced enough to keep them in good shape. The old growth should be occasionally thinned out and the suckers and root sprouts removed when they appear. The best time, however, for pruning all shrubs is when they have done flowering. The Hydrangea paniculata grandiflora should be severely cut back and thinned early in Spring.

Pruning Evermeens. Use the knife occasionally to thicken the growth and preserve the shape. This can be done in April or May, just before trees start to grow.

The Common or English name of each varicty is placed first in black-faced, conspicuous type. The botanical name of variety follows in parenthesis. 


\section{Deciduous Trees}

\section{Brief Suggestions for the Selection of Trees for Various Uses}

Street or Avenue Trees. American Elm, Sugar, Soft and Norway Maples, White Ash, American Linden or Basswood, Catalpa, HorseChestnut and Box Elder.

Lawn and Park Trees. White and CutLeaf Birch, Schwedler's Purple Maple, Norway Maple, Catalpa, Bechtel's Double Flowering Crab, Double Flowering Thorns, American Elm, Camperdown Elm and Teas' Weeping Mulberry.

Trees That Thrive in Moist Locations. American Elm, American Lindens, White Ash, Poplars, Willows, and Box Elders.

\section{Ash - Fraxinus}

A class of large ornamental trees, adapted to a great variety of soils. Of quite rapid growth and possessing many desirable characteristics for lawn, street, and park planting.

White Ash (Americana). Lg. A well known timber tree. It attains a large size and is of great value for timber. A good street tree in many sections, is a rapid grower. It produces a broad, round head and has a straight clean trunk. While young, its foliage has a remarkably soft and mellow appearance.

Green Ash. Lg. This species is of the greatest value in the prairie states of the Northwest. Although not so tall a grower nor so rapid in growth, it is much hardier and bettel adapted to the extreme conditions of this section. It is valuable for street planting as a shade tree and for all kinds of prairie timber culture.

\section{Beech - Fagus}

The Beeches are hardy and thrive best in a deep, rich clay soil. Best success will be obtained by planting small specimens and pruning severely at time of transplanting.

American Becch (Americana). 40 to 60 feet. One of our finest native trees.

Rivers' Purple Leaf Beech (Sylvatica Riversi). 30 to 40 feet. The finest of all purple-leaf trees, as the foliage has fine coloring throughout the entire season.

\section{Birch - Betula}

American White Birch (Populifolia). Med. A small or medium sized, graceful tree. Thrives well in even poor and dry soils. The bark is a grayish white.

Paper or Canoe Birch. The brilliant white bark is wonderfully effective, particularly in Winter and when planted against evergreens. 50 to 60 feet.

Weeping Cut-Leaf Birch (Pendula laciniata). Med. This magnificent tree is, without question, the most popular and the most planted of all pendulous or so-called weeping trees. It is a tall, slender tree, yet with vigorous growth It has an erect central trunk, somewhat pyramidal in shape, with graceful, drooping branches and white bark on all the old wood.

\section{Butternut, Walnut - Juglans}

This species furnishes us two of our grandest, native, ornamental trees. In congenial soils they are very valuable trees for all kinds of lawn, park or street planting. They have a characteristic foliage not found in any other species and a delightful effect is produced wherever used.

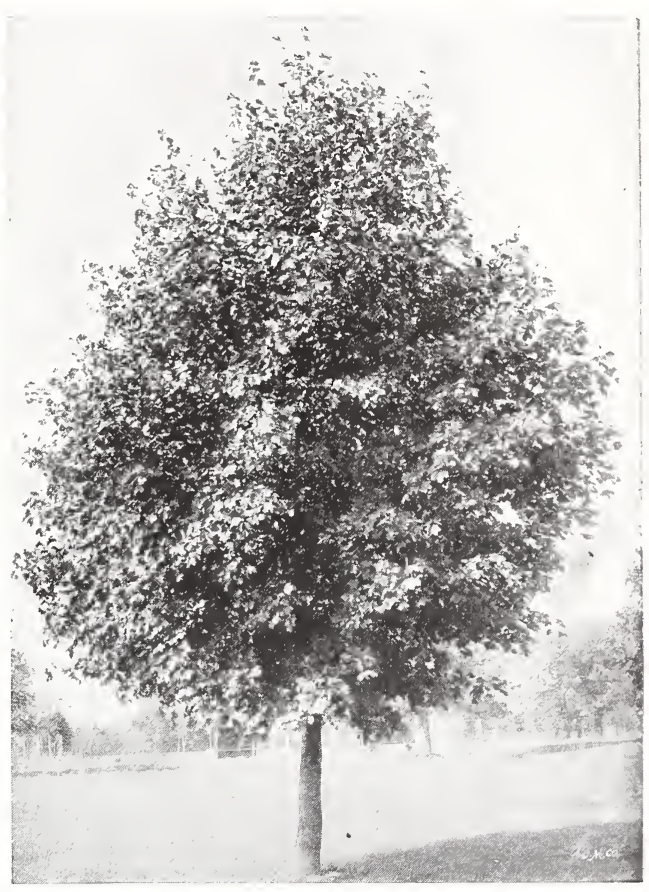

White Ash.

Butternut, White Walnut (Cinerea). Lg. Very much resembles the Black Walnut. It is a moisture-loving tree and succeeds best on low, rich soils. A broad, open top tree, with light green, compound foliage and gray bark.

Black Walnut (Nigra). Lg. Like the Butternut, it prefers a damp soil. It, however, is a satisfactory tree on lighter soils though slower in growth. It makes a uniform street tree and is also a very fine shade tree.

\section{Catalpa}

Speciosa (Western). Med. to Lg. A handsome, large-foliaged tree; fine for lawn or landscape planting, and forming a valuable street tree. Its fine racemes of flowers in early summer is a distinguishing feature of it, and its heavy crop of long, pendent "beans" in Autumn is unique. Much used of late years for railroad ties, fence posts, etc. The wood, though soft, is very durable.

Bungei (Globe-Headed Catalpa). A rapid growing tree with a globe-headed mass of large, heart-shaped, deep green leaves lying like shingles on a roof, always making a symmetrical head; excellent for formal effects; not hardy in Wisconsin.

\section{Cherry - Cerasus}

No garden is complete without these beautiful trees. Besides their ornamental qualities they have the added advantage of attracting birds, which feed upon the fruits. Cherries thrive in any fertile soil.

Double Pink Flowering Cherry (Avium var. rosea plena). Med. Similar to var. alba plena, but with pink flowers.

Double White Flowering Cherry (Avium var. alba plena). Med. A very fine, freeblooming variety, with double flowers in May. The individual flowers resemble miniature white roses. 


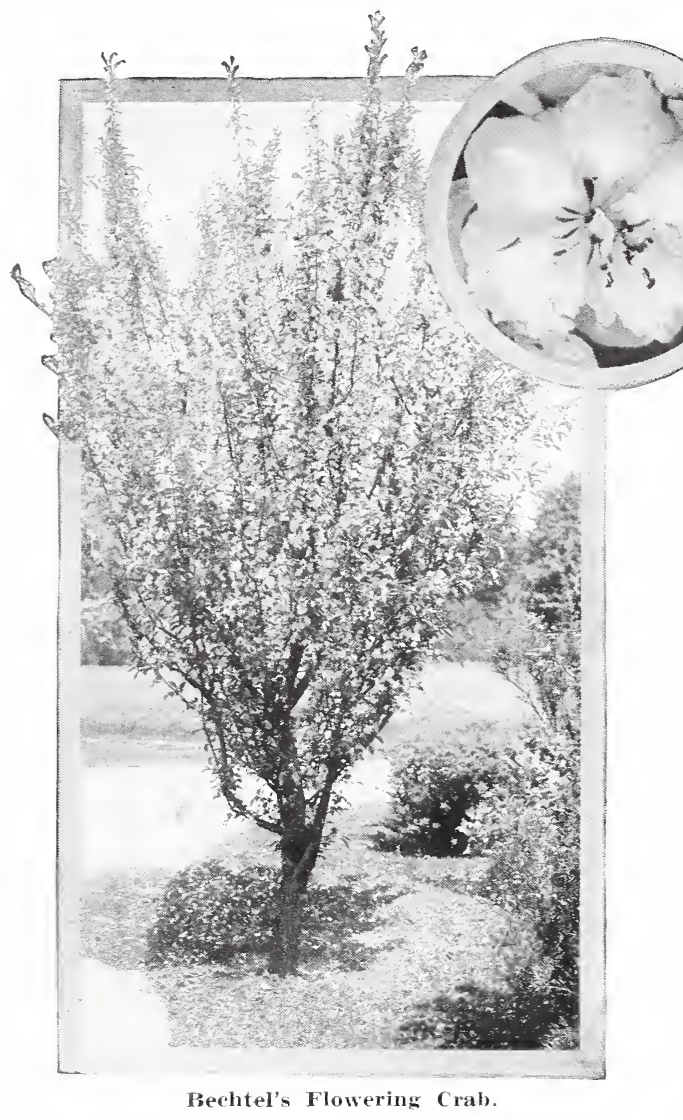

DECIDUOUS TREES-Continued.

\section{Crab, Flowering - Pyrus}

Bechtel's (Angustifolia). A low, bushy tree, rarely over 20 feet in height. It is the most beautiful of all the fine varieties of Flowering Crabs. At a distance the tree seems to be covered with dainty little roses of a delicate pink color. Blooms when quite young and is very fragrant. Makes one of the handsomest lawn decorations in our list, and planted in front of evergreens, forms an interesting picture.

\section{Elm - Ulmus}

Stately trees combining grace of habit and beauty of outline. They are hardy and of extremely rapid growth when planted in moist loam. No lawn or landscape is complete without them.

American White Elm (Americana). Lg. One of the largely used trees for street planting and as a shade tree for lawns and parks. It is the most characteristic tree of this region and one of the most beautiful. Its habit is at once majestic and graceful, and the wide spreading tree, borne usually at a considerable height on a straight and shapely trunk, affords ample shade and shelter.

Camperdown Weeping Elm. When grafted they grow from 6 to 8 feet high; form a large, handsome head; branches often extend horizontally several feet before drooping. A fine varjety.
We are growing in our nurseries several thousand budded and grafted Elms, and believe at the present time there are not over four or five nurseries in the United States that can supply you with Flms of this type.

Moline EIm. This variety of Elm is propagated by budding or grafting. The tree is of an upright habit of growth with smooth bark and dark green foliage. Grafted or budded Elms are very valuable for street planting. Every tree is uniform, hence are much more desirable than the Common American White Elm which is grown from seedlings.

Vase Elm. This is another selected type of American Elm which was named Vase for the a vase shape. This variety is also smoothbarked, upright growth and carries handsome foliage. The Vase Elm is propagated by budding or grafting, hence all trees are uniform and are very desirable for lawn or street planting. Close observers have undoubtedly noticed repeatedly that there is a very marked variation in the Common American White Elm, which is grown from seedlings.

\section{Hackberry; Nettletree - Celtis}

Occidentalis. A rare native tree that deserves much more general planting. Its light green leaves are glossy, pointed, almost entirely free from insects; the branches spread horizontally, forming a wide, elm-shaped head of medium size. Vigorous, hardy and healthy, thriving in all soils.

\section{Honey Locust - Gleditsia}

Honey or Sweet Locust (Triacanthos). Med. A rapid growing tree; delicate foliage of a beautiful, fresh, lively green, and strong thorns; makes an exceedingly handsome, impenetrable and valuable hedge.

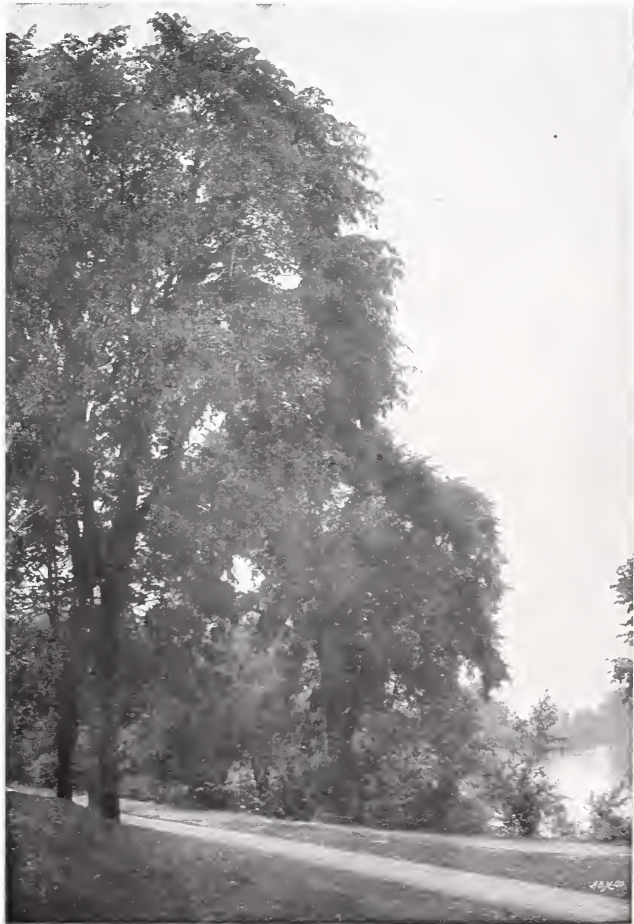

American Elm. 
European Linden (Platyphyllos). Broadleaved European Linden. Lg. It forms a broad topped tree, with large, handsome foliage. It flowers early in the season. A desirable tree for either avenue or lawn planting. Not hardy in Northern Wisconsin.

\section{Horse-Chestnut - Aesculus}

American Horse-Chestnut or Buckeye (Glabra). A handsome, medium sized tree, with spreading branches and peculiar fiveparted foliage. In Spring it bears fine, upright clusters of greenish white flowers, which are followed by lar e, odd, prickly seed pods inclosing the well known buckeyes.

European Horse-Chestnut (Hippocastanum). A tall, massive, stately tree, with an immense, round crown and strong, stiff branches clothed with large, five-parted foliage casting the densest shade of any deciduous tree. In the Spring it is one of the most beautiful sights when it displays its innumerable, showy, erect clusters of spotted white flowers.

\section{Larch - Larix}

Trees of pyramidal outline of great hardiness. They grow in almost any kind of soil, but prefer a moist, well drained situation.

European Larch (Europea). 40 to 50 feet. A lofty, rapid growing pyramidal tree, with small, drooping branches and delicate feathery foliage. Valuable for timber.

\section{Linden, Basswood - Tilia}

The Lindens grow fast, forming noble trees of rounded outline, and casting a dense, cool shade. The leaves are large and cordate, the flowers light yellow, exhaling a delightful citron odor. All are among our best large-growing street and avenue trees; fine also for specimens and grouping.

American Linden, Basswood (Americana). Lg. A well known, stately tree with large, heart-shaped leaves of a pleasing green color. A vigorous grower of pyramidal habit when young, but eventually a large, round-headed tree. A valuable lawn tree and should be more used for this purpose.

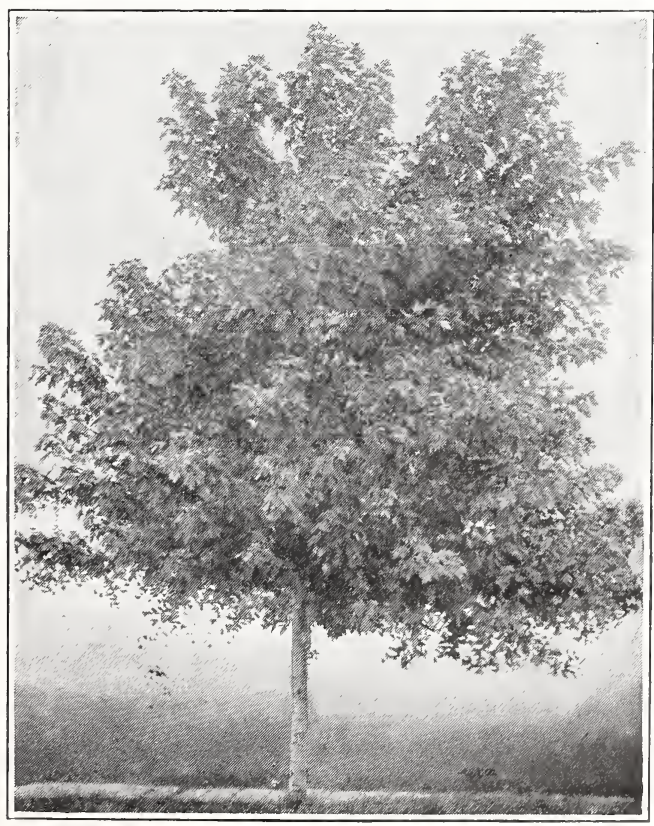

Soft or Silver Maple.

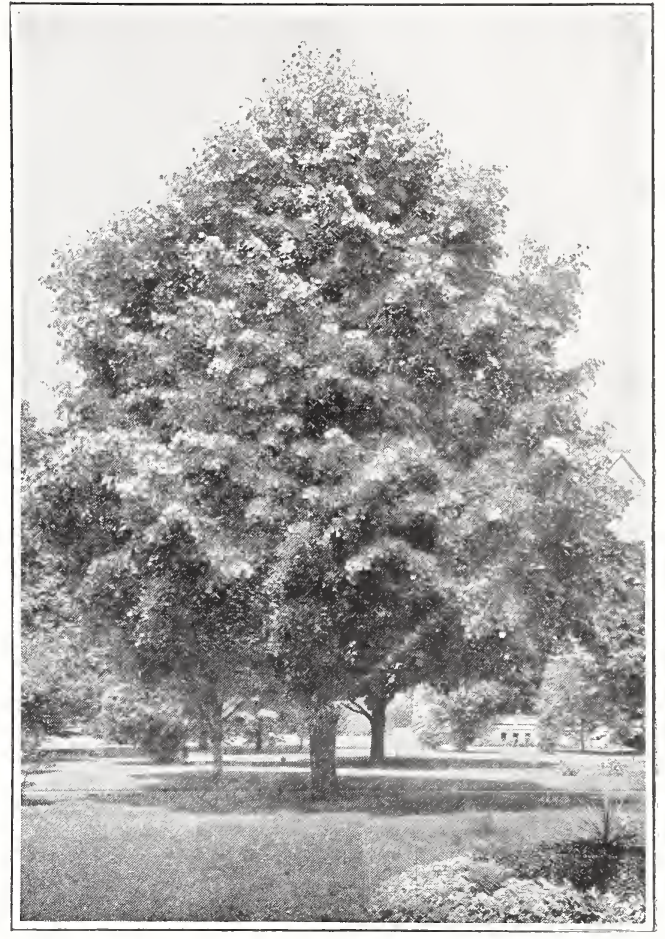

American Linden.

\section{Maple - Acer}

Box Elder: Ash-Leaved Maple (Negundo). Med. A rapid growing variety, with handsome light green foliage and spreading head. Very hardy, and succeeds in many sections where other varieties do not thrive.

Norway Maple (Platanoides). Med. Most popular species of the Maple group, either for the lawn or street planting. It forms a perfect, rounded head, with large, deep green foliage, is very hardy, easily transplanted, very compact in form, grows rapidly, and is exceptionally free from injurious insects.

Schwedler's Purple Maple. Med. The young shoots and leaves are of a bright purplish and crimson color. They change to a purplish green in the older leaves. A most desirable ornamental tree for the contrast of its foliage.

Siberian Maple (Tataricum var. ginnala). A graceful small tree or shrub, native of China and Japan. Leaves three-lobed, the middle division much elongated, their edges serrate, bright green, turning to a brilliant red in Autumn. Handsome and desirable. 8 to 10 feet.

Soft or Silver Maple (Dasycarpum). Lg. A well known ornamental tree, with wide spreading, slender branches. Has been much used as a street tree. It is valued for windbreaks on account of its quick, upright growth.

Sugar, Hard or Rock Maple (Saccharum). Lg. A beautiful and always popular tree, growing on a smooth trunk and forming a dense, oval head. The foliage is large and handsome and of a rich, pleasing green, turning to beautiful shades of orange-yellow and red in the Autumn. It makes a splendid and uniform street tree, and is adapted to nearly all kinds of soll. 


\section{DECIDUOUS TREES-Continued.}

Wier's Cut-Leaved Silver Maple (Wieri). Ned. This distinct variety is one of the most beautiful of our hardy trees, having cut or dissected foliage. Its growth is rapid, the shoots slender and drooping, giving it a habit almost as graceful as the Cut-Leaved Birch.

\section{Mountain Ash - Sorbus}

Imerican Mountain Ish. One of our most attractive native trees. Its habit is much the same as the European variety, but is much hardier and the bark is lighter in color. It produces its berries when quite young, which are in large clusters and of orange color. Especially fine for planting among tall shrubbery, with its brilliant berries. 18 to 20 feet.

European Mountain Ish (Aucuparia). Very beautiful, with straight, smooth trunk. Foliage deep green, turning yellow in Autumn. Erect growth, 20 to 30 feet high. White flowers in May, followed by bright orange-red berries which cling all Winter. Interesting for lawn or park.

Weeping Mountain Ish. The branches of this distinct variety are of a decidedly straggling pendent character, turning and twisting in every direction, each branch apparently struggling to be as different from its neighbor as possible, producing a pleasing effect. 10 to 12 feet.

\section{Mulberry - Morus}

Hardy ornamental trees, thriving in almost any soil. The sweet, fleshy fruits are a great attraction to birds, and on this account they are planted extensively.

Russian Mulberry (Tatarica) Sm As commonly seen it is a low-growing, bushy-topped tree, with small and much lobed leaves. The foliage is very successfully used as food for silkworms.

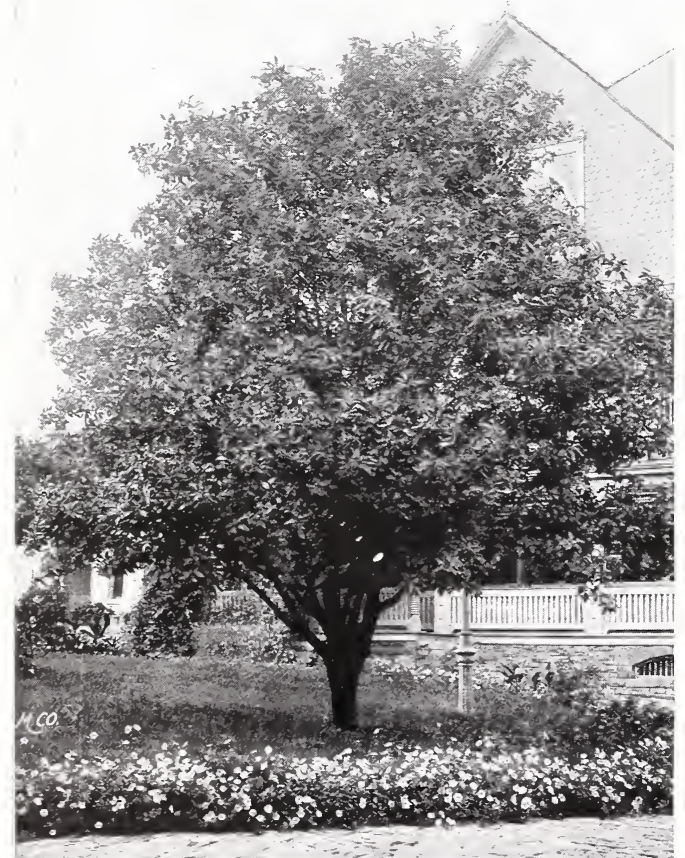

Furopean Mountain Ash.

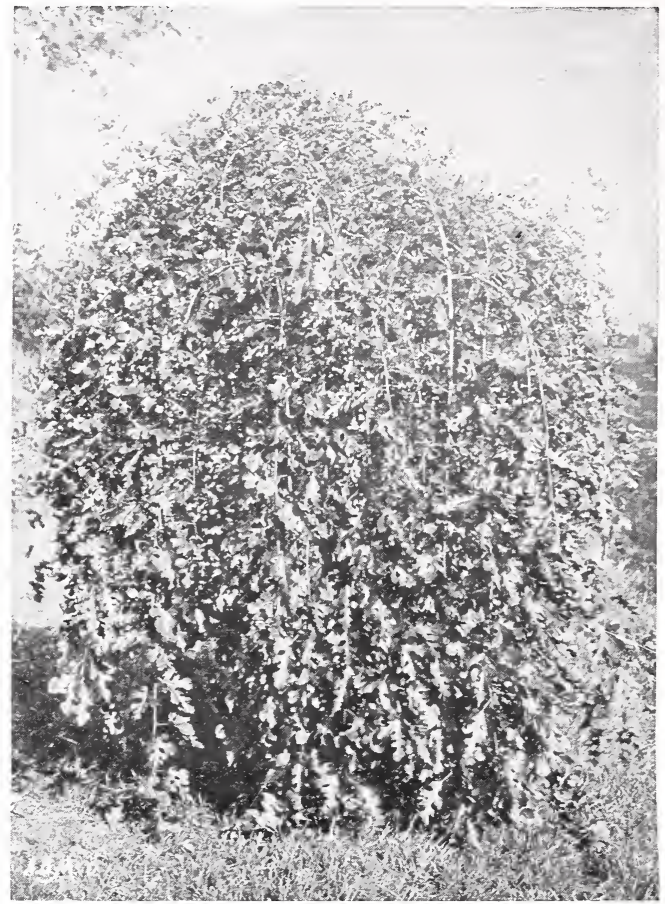

Teas' Weeping Mulberry

Veeping Russian Mulberry (Tatarica pendula). One of the most graceful of weeping trees. Forms a perfect umbrella-shaped head, with long, slender branches, drooping to the ground, parallel to the stem.

\section{Oak - Quercus}

Pin Oak (Palustris). Lg. Peculiarly handsome tree when young; used for avenues. Leaves deep green, turning to red in the Fall, finely divided. Drooping branches.

Red Oak (Rubra). Lg. A broad tree, rich foliage which turns to a bronzy red in the fall.

\section{Poplar - Aspen, Populus}

Bolleana. Pyramidal Silver Poplar. of recent introduction. A very compact, upright grower, resembling the Lombardy Poplar. Leaves glossy green above and silvery beneath, with a trunk of a bluish hue. Med.

Carolina Poplar. Lg. A very distinct tree in habit of growth and making a straight, upright, somewhat pyramidal head. It is of extremely rapid growth, straight and regular in habit, which fact makes it particularly desirable as a quick growing street tree. The foliage is large, thickly borne, bright and glossy.

Canadian Poplar (Canadensis). Lg. It is extremely hardy. It grows as far north as Edmonton in northern Alberta. The tree is especially adapted to severe and exposed localities.

Lombardy (Fastigiata). A tall, picturesque, spirelike tree, fine for formal planting, such as along avenues or marking the boundary of grounds.

Norway Poplar (Called by some Sudden Saw Log). Very similar to the Carolina Poplar. We consider it a little more stocky grower than the above, and equally as good in every way.

Simon's Pyramidal. A new Poplar recently introduced by the Bureau of Plant Industry. Similar to the Lombardy Poplar in type of growth, with dark glossy foliage. 


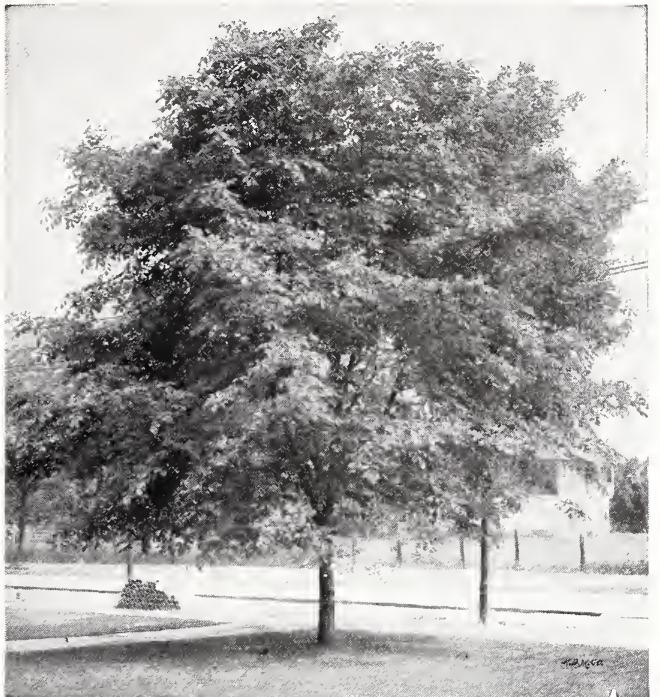

Norway Maple. (See page 23).

DECIDUOCS TREES-Continued.

\section{Sycamore, Plane Tree - Platanus}

Rapid growing, hardy trees of great adaptability, but thriving best in moist loam. The American species may be recognized by the single "buttons" drooping on their long stalks.

Imerican Sycamore (Occidentalis). Lg. A large, rapid growing tree, suitable for street planting. Attains a height of 40 to 50 feet.

\section{Tree of Heaven - Ailanthus}

Peculiar tropical-looking tree, with long sprays of odd pinnate foliage, much like Sumac. Fine for street planting, as it endures the city dust and smoke remarkably well. Grows very tall and spreading. Not extremely hardy.

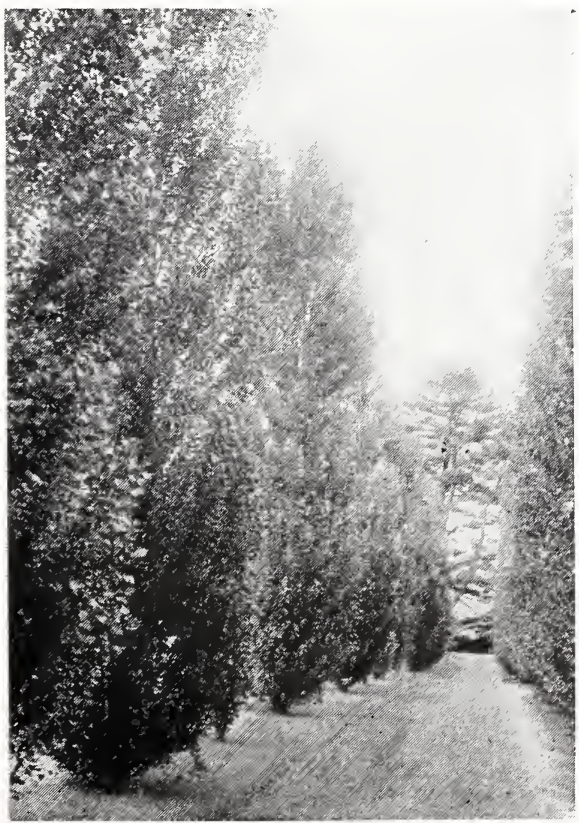

Lombardy Poplars.

\section{Thorn - Crataegus}

The Thorns are among the most beautiful flowering trees. They are generally dense, low growers, occupying comparatively little space and well adapted to beautify small grounds. The foliage is varied and attractive, flowers very showy and often highly perfumed. The fruit is very effective and ornamental in $\mathrm{Au}$ tumn.

Double White (Alba fl. pl.) Has small double white flowers.

Paul's Double Scarlet (Pauli). Flowers larger, deep carmine-scarlet. Superior to any other variety.

\section{Willow - Salix}

Golden Willow (Aurea). Lg. At the present time one of the most planted of all Willows and a very important tree, both from an economical and ornamental standpoint. It makes a round topped tree of symmetrical form. One of its strongest ornamental features is the bright, clear, golden yellow bark, which offers a pleasing contrast wherever it is used. Valuable for hedge and windbreak purposes.

Laurel Leaf or Bay Leaf Willow. Sm. An ornamental variety of upright growth, forming a round head. Bark is brownish green. Foliage is a deep shining green, closely resembling that of the Laurel. Thrives equally well on high or low ground. An especially desirable variety to plant near the water.

Wisconsin Weeping Willow (Babylonica). Lg. This is a variety of the above which is of particular value in the North, as it is much hardier and seems otherwise better adapted to the extreme conditions of this section. It is of drooping habit though not so pronounced as the Kilmarnock type.

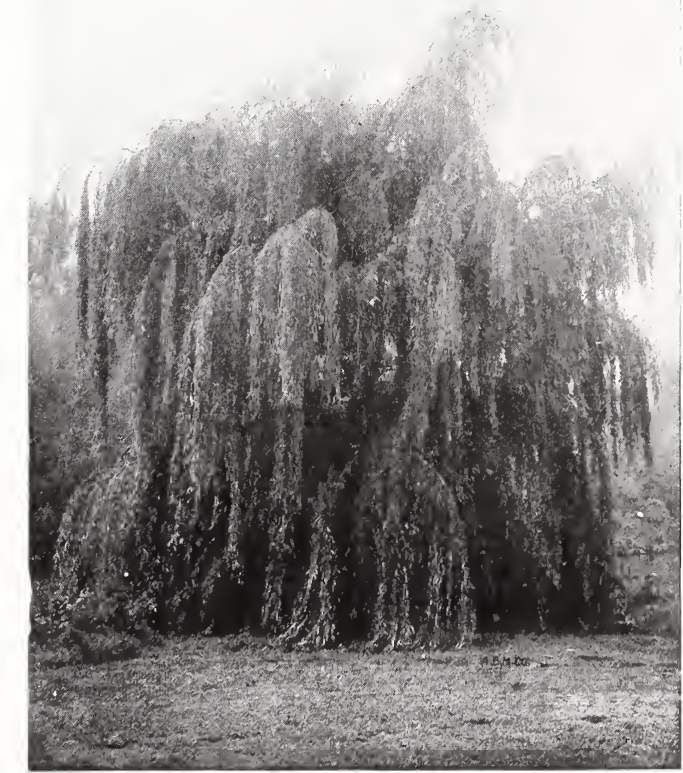

Wisconsin Weeping Willow. 


\section{Beautifying the Home Grounds}

Endeavor to picture in your mind the appearance of the work when completed, and also what the result will be in after years when the trees and plants have attained their growth.

The first step will be to locate your drives and walks, these should be conveniently placed and as few and short as possible; a slight curve, however, is more graceful and pleasing to the eye than a straight line. In grading be sure to have at least a foot of good soil on top. try to avoid steep terraces: slopes of easy

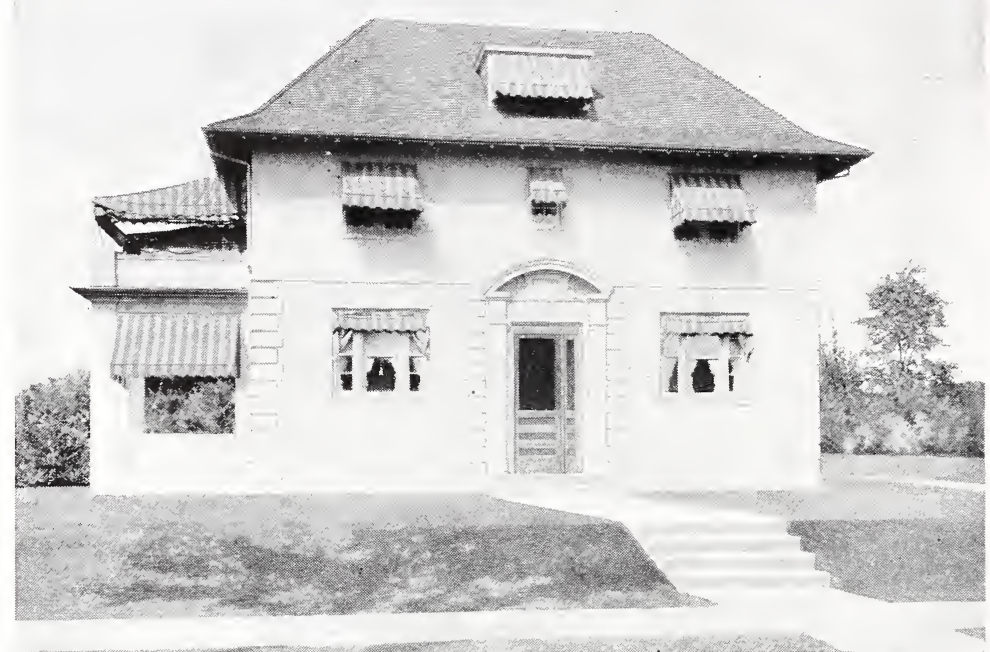
natural curves will keep in order much longer, seldom requiring repair and are easier to care for. If a steep bank is unavoidable, it may be planted with suitable shrubbery in groups.

In placing trees and shrubs, preserve the desirable views, screening the objectionable. Trees with bold outlines, planted at a distance will give character, while masses of the smaller growing and more select varieties will add charm to the foreground. Procure such as are best adapted to the location, are easily taken care of and that will produce a variety of flowers and foliage to make your grounds attractive throughout the year.

In arranging plantings, leave as much open lawn as possible. On the margins plant in masses and beds with large bays and projections to which later new acquisitions may be added. Consider the size of the plants at maturity, placing the largest in the rear and those of dwarf habit in the foreground. Give rach room for full development. If immediate

\section{Betore Planting.}

ffect is desired, the planting can be closely made by placing first what is to remain permanently, allowing ample room for development, then filling between these with plants which are later to be removed.

We offer a wide assortment of such ornamental stock designed to meet the requirements of our patrons. Many of our trees are nativeand therefore we know they will thrive better than many imported and unadapted species.

\section{Deciduous Trees}

There is an ornamental deciduous tree for almost every purpose-whether for shade, for hiding objectionable sights, for beauty of flower, or utility. Knowing them as we do, there is not one but has its faults, and therefore careful choosing of your trees should follow. We commend the use of shade trees not only as specimens, but in groups thickly planted and bordered with shrubs. We carry a very complete line of adaptable shade trees, properly srown with heavy roots to insure vigor.

\section{Evergreens}

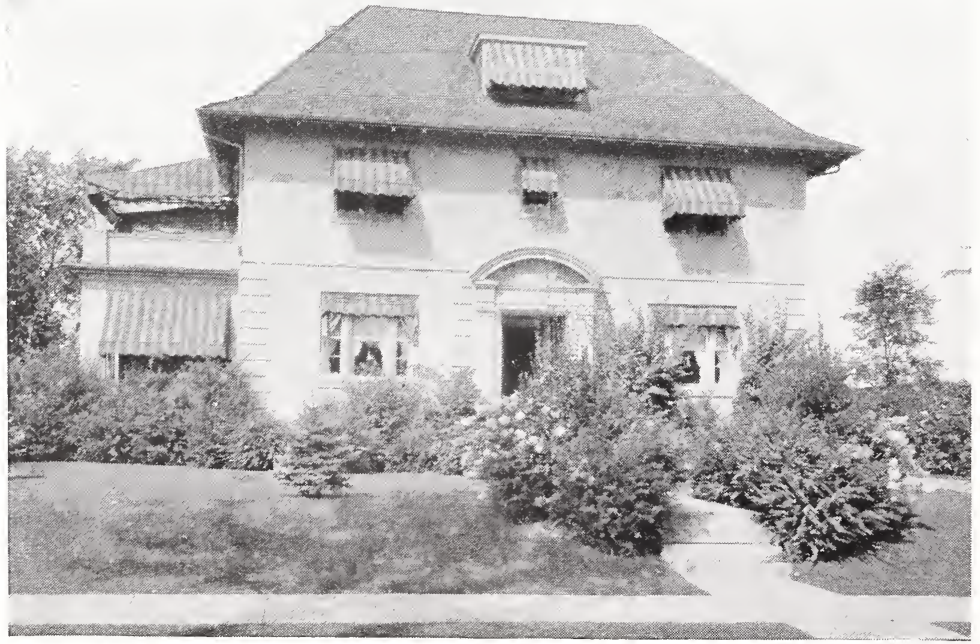

Two Years After Planting.

The Evergreens are indispensable in some features of ornamental gardening. They are especially valuable for screens and windbreaks, for a background against which to group trees with beautifully colored leaves or branches, and for Winter decoration. In fact, in the northern states the Pines, Spruces and other native Evergreens are so well adapted to the climate and soil that they are quite as i m portant in all branches of ornamental planting as the deciduous trees and shrubs.

Choice Evergreens should be dug and shipped with a ball of earth as an extra precaution that plants will arrive in good condition. 


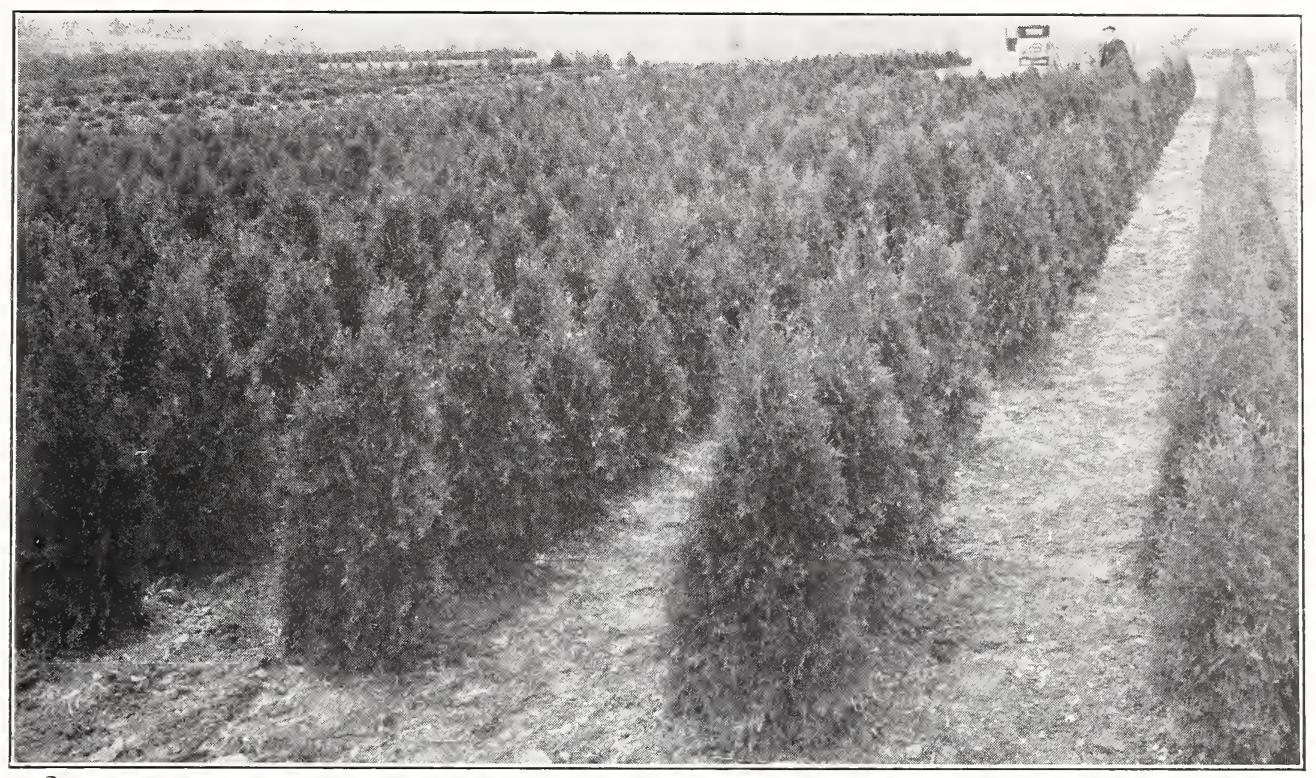

Thousands of Specimen Pyramidal Arbor-Vitaes on our Grounds. The President of Our Company and His Car in the Background.

\section{Coniferous Evergreens}

We have specialized on Evergreens for many years and this year we have the very largest and best assortment in the Northwest. Each tree receives our individual attention. The soil here is peculiarly adapted for the growth of Evergreens and is such that they can be dug and shipped with a solid ball of earth.

Evergreens are one of the greatest factors in the successful planting of the home grounds and larger landscapes, for they combine beauty in the highest degree with lasting qualities and usefulness. The right choice and wise use of Fvergreens means a home equally beautiful at all seasons, and having the utmost comfort of privacy and shelter.

\section{Arbor-Vitae - Thuya}

American Arbor-Vitae (Occidentalis). Med. Also erroneously called White Cedar. The best known and most valuable of this genus. In cultivation this species is best known from its widespread use as an ornamental hedge. It is of a bright, healthy green with an abundance of foliage and of natural pyramidal shape. adapting it to hedge purposes. As it stands severe pruning, it is easily maintained in a low hedge of almost any desired height or shape.

Douglas Golden Arbor-Vitae (Douglasi aurea). A really valuable golden form orioinated by Robert $H$. Douglas. A good golden color, not so bright as Peabody's, but a superior grower, forming a broad, bushy, heavy specimen. Jts unusual bright golden color adds contrast and a novel touch when planted with other Evergreens. Can be easily sheared and kept at any height or form desired.

Globe Arbor-Vitae (Globosa). Sm. Of dense, dwarf habit, globular in outline; color a pretty light green; requires no shearing and always in good form.

Peabody's Golden Arbor-Vitae (Occidentalis lutea). A bright golden yellow form of the Arbor-Vitae; of dense habit, and with short branches, growing in pyramidal shape. It is of extra hardy constitution, and adds a pleas- ing touch of brightness to the rest. It retains its color well all through the Winter, and at all times is very effective, forming a brilliant contrast to the others.

Pyramidal Arbor-Vitae (Pyramidalis). Forms a tall, slender column of dark green, 20 to 40 feet high, similar to the Irish Yews. A very valuable variety for many kinds of ornamental plantings, and a rich and attractive variety wherever columnar effects are desired. Very desirable for single specimen planting on the lawn or elsewhere. It keeps its fine color well all season. Very hardy.

Siberian Mrbor-Vitae (Wareana). Med. A very desirable type of the Arbor-Vitae. Forms a dense, rather conical body of very symmetrical habit and pretty either in groups or singly. The foliage is stiff and heavy and of a deep, rich green color.

Tom Thumb Arbor-Vitae. A heath-leaved variety; hardier and lighter green than Ericoides. Has beautiful, soft feathery green foliage which changes to bronze in Winter.

\section{Fir - Abies}

Balsam Fir (Balsamea). Lg. A handsome, symmetrical tree, especially when young, with beautiful leaves, dark green above and lighter beneath. Will grow on wet ground as well as in better soil.

Concolor Fir (White Silver). An elegant, picturesque Colorado species; long, leathery leaves with glaucous tinge when young, becoming pale green with age. Branches arranged in horizontal whorls. One of the brightest and best Evergreens for the lawn.

Douglas Fir. A Colorado species. Forms a large, spreading pyramid of light green. 40 to 50 feet high.

\section{Hemlock - Tsuga}

Hemlock Spruce. A beautiful and graceful native tree with drooping branches and dark, delicate foliage of green. It makes a fine lawn tree or ornamental hedge. 


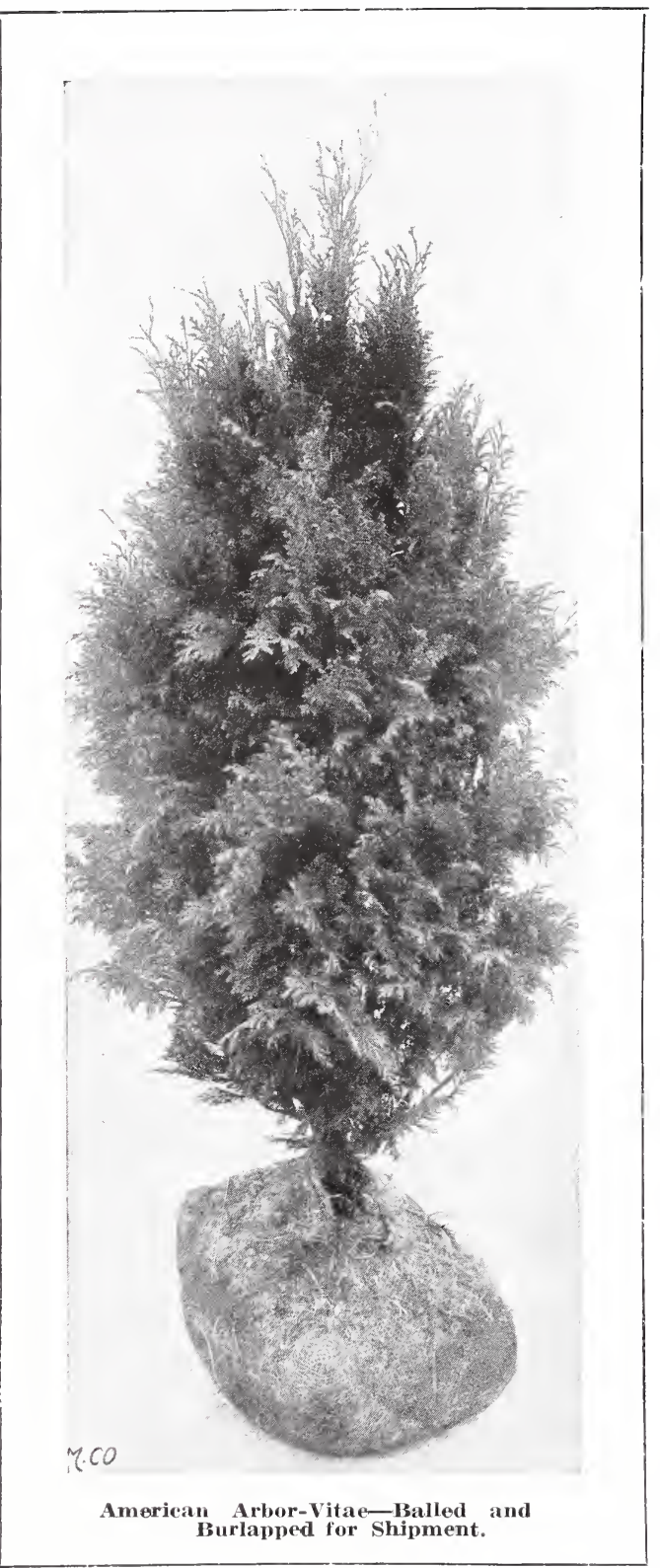

\section{Juniper - Juniperus}

Conifers of extremely easy growth, hardy. and long lived. Effective in landscape plantings as the variation in form and color tints are exceedingly pleasing when properly grouped.

Communis Juniper (Canadensis). The well known, valuable, many-stemmed dwarf Juniper. Rarely exceeds two feet in height. It is at home on sandy or gravelly hillsides fully exposed to the sun, where single plants often reach 15 feet or more in diameter, but can easily be trimmed to any size wanted.

Counarti Juniper (Counarti). This is a pyramidal, compact grower of medium size, reaching 15 to 20 feet. With only a few moments trimming each Spring, it can be kept at any size wanted. It has rich green, heavy tufted foliage. Occasionally some trees bear a neavy crop of blue and silver colored berries, which adhere late in the Autumn and are greatly enjoyed by some birds. Superior to Schotti.

Glauca Jumiper (Glaucus). In this variety, the whole young growth are of almost siıvery whiteness, which changes to beautiful bluish green in winter. It never grows very large, not over 15 to 20 feet, and it can be kept even smaller if desired. The Glaucus Juniper is foremost among the interesting group of Junipers that have been developed from the Juniperus virginiana (Red Cedar).

Lee's Golden Tipped Juniper (Elegantissima Lee). Here is a tree that will give varlation to the green and blue colors of other Evergreens. You would not want an entire planting of them, but a single tree here and there is very pleasing.

Pfitzer's Juniper (Pfitzeriana). One of the most beautiful and attractive Junipers. Its form is different, not growing so pyramidal as most of the others, but more open, with graceful branches that appeal to most lovers of Evergreens. We have been growing this for a number of years, but it is a new and rare type. 8 to 10 feet.

Red Cedar (Virginiana). Lg. Probably the best known species of this whole family. The Red Cedar is indigenous throughout Wisconsin and the entire Northwest. It does well in dry and exposed locations, and is admirably adapted to windbreak planting. being especially valuable in mixod plantings.

Savin Juniper (Sahina). Sm. Of dwarf, spreading growth. Hardy and thrives well on poor soil; a favorite for rockwork.

Schott's Juniper (Schotti). In general appearance is like Juniperus Counarti. It is distinguished, however, by its bright, rather yellowish green foliage. Very hardy; growing 15 to 20 feet and stands almost any amount of trimming.

Trailing Juniper (Procumbens). Reaches from 10 to 15 feet in diameter, but can be kept smaller by trimming. It never grows over 8 to 12 inches high, but makes a rapid growth of long branches that cling tight to the ground. It can be used in almost any planting. For beds, for low borders, terraces, hillsides and rock gardens.

\section{Pine - Pinus}

Austrian Pinc or Black Pine (Laricio var. austriaca). Lg. A European Pine of much ornamental merit. It makes a tall, handsome tree with broad, oval head. One of the most important conifers for specimens or mass planting.

Mugho Pine (Mughus). Sm. A low spreading Pine and very useful in lawn planting. In foliage it is a true Pine with stout, bright green needles of medium length. Valuable for planting on rocky ground and hillsides.

Ponderosa Pine (Bull Pine). A native of the West. The best tree for the semi-arid regions. Thrives in most any soil. Resembles the Austrian Pine. Extensively planted in the West for windbreaks.

Red Pine (Resinosa). Also known as Norway Pine. Native of the northern part of the United States, reaching its greatest development in Northern Wisconsin. One of the most ornamental trees for the North. Needles are long and soft; a good green color, not so dark as the Austrian Pine.

Scotch Pine (Sylvestris). Med. to Lg. This Pine is one of the most important timber trees of Europe. By many it is considered of equal ornamental merit with the White Pine and Norway Pine and is a very desirable tree for evergreen groups. 


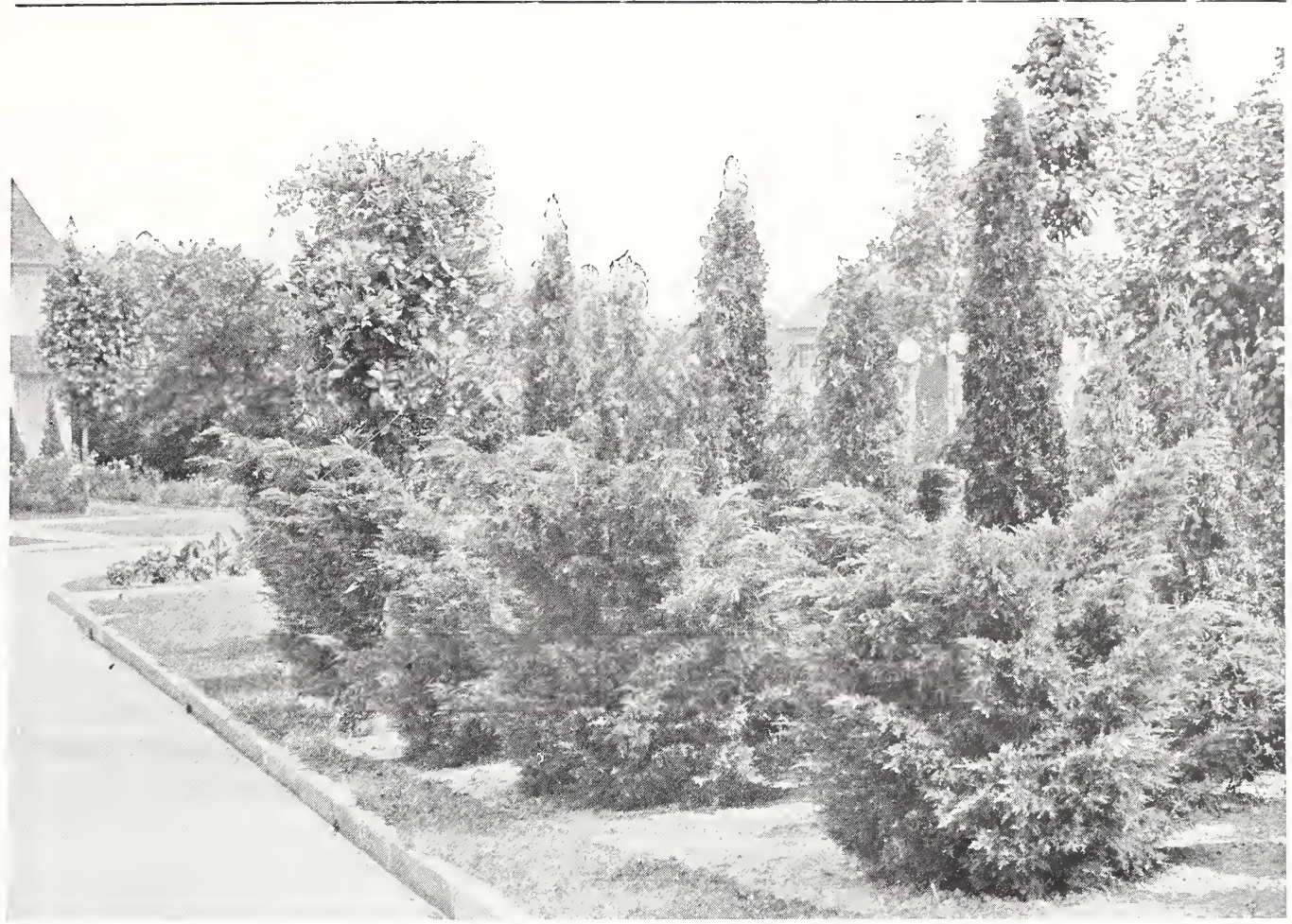

Juniper Pfitzeriana in Foreground.

White Pine (Strobus). Lg. Our native Northern White Pine is famous as a stately conditions. It is tall and straight with slender, glaucous foliage. somewhat tufted at ends of the branches.

\section{Spruce - Picea}

Black Hills Spruce (Canadensis). In describing to our patrons the different varieties of Spruces, we wish to call particular attention to the Black Hills Spruce. The very smallest trees of this variety soon form round, sturdy, compact bodies. As the tree grows and develops it adds to this particular style of growth and in most cases is found to be the most compact growing Evergreen belonging to the spruce family. It retains its branches close to the ground even in old trees.

Colorado Blue Spruce (Pungens glauca). Other trees there are of almost every imaginable form and color, but here is truly the culmination of Nature's highest effort to produce the beautiful. Picture in your mind a perfectly shaped tree with an abundance of heavy foliage of a rich glistening blue, which flashes and sparkles in the sunlight, and you form only a faint idea of the magnificent beauty of this truly marvelous tree. The glory of the Blue Spruce is in its foliage, which is an intense steel-blue. It has created a sensation throughout the United States and Europe, and is indeed a triumph in Evergreen growing.

Koster's Blue Spruce (Pungens Kosteriana). The very best of the Blue Spruces. Foliage is silvery blue, densely crowded on the many branches. Our stock of this beautiful and popular Evergreen has been grown with great care from stock which we know is the genuine Koster's, and can guarantee its true blue color and character. In height it is the same as the Colorado Blue Spruce.

Norway Spruce (Excelsa). Lg. This is the most popular of the foreign spruces and has been extensively planted, especially in the northern states. It is of rapid growth, and is a handsome tree with graceful habit and dark green foliage.

White Spruce (Alba). Lg. A well known native tree and one of the most magnificent ornamental Evergreens for all purposes. It forms a loosely symmetrical tree with rather pendent branches toward the base. As a specimen tree on good soil, it is a shapely feature for any planting.

\section{Yew - Taxus}

Cuspidata (Abrupt-Leaved Japanese Yew) Upright growth and dense, very dark foliage. Valuable because it is especially hardy and rich in appearance.

Brevifolia. A very handsome form of the above. Spreading and very hardy. We consider it the best varicty to plant.

\section{F. CRILLY \& COMPANY \\ Room 204 35 S. Dearborn Street} Chicago, Ill., Nov. 14, 1924.

McKay Nursery Co.,

Madison, Wis.

Gentlemen :

Please find enclosed pictures of Evergreens, which I trust will reach you in good time. You have my permission th use these pictures any way you see fit. These Evergreens as shown on these pictures are planted around my Summer house adjacent to my residence overhanging the bluff within seventy-five feet of the water's edge of Lake Michigan at 375 Sheridan Road, Winnetka, Illinois. I wish to add that these Evergreens purchased from you are the finest specimens I have ever seen and this also is the opinion of a number of experts on Evergreen planting. You may also use this letter and use my name as a reference to any prospective clients.

Signed, EDGAR CRILLY.

Mr. Crilly purchased a carload of our stock. 


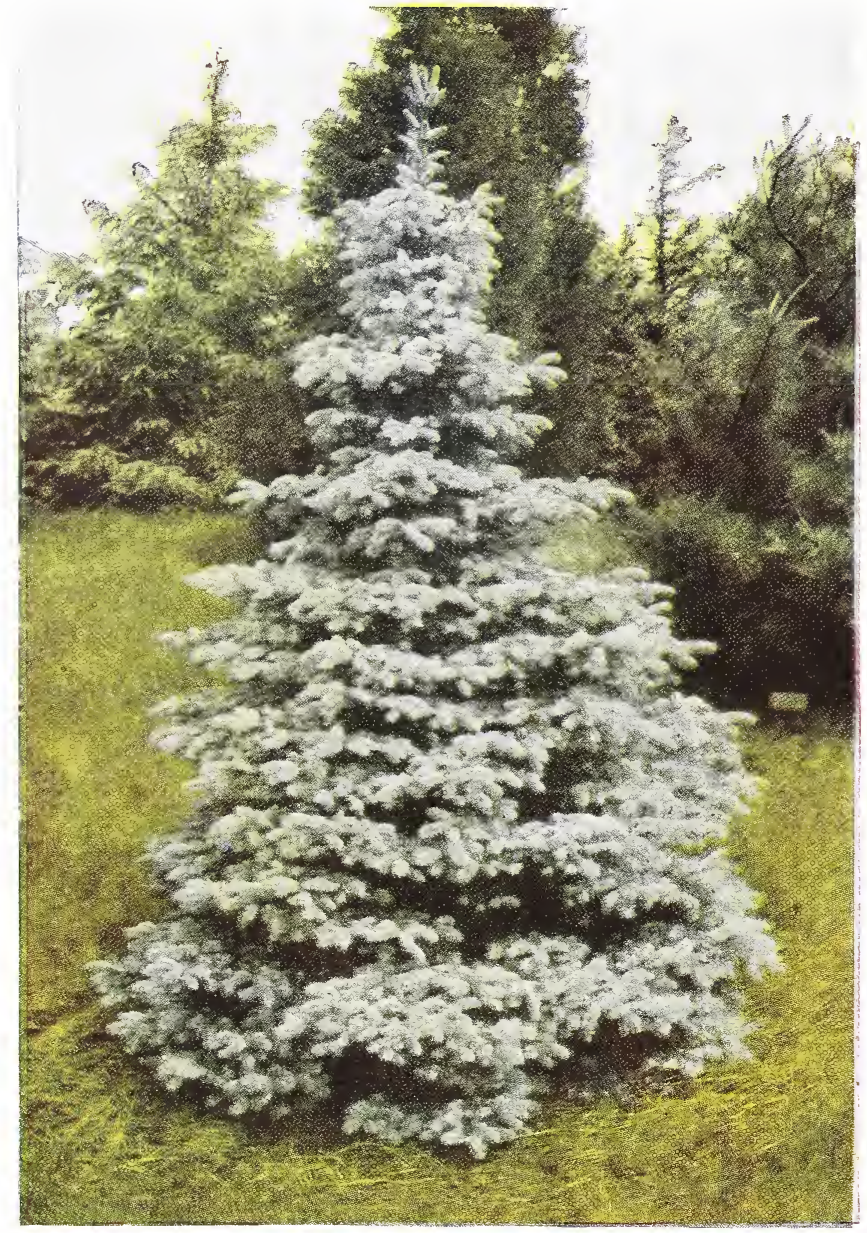

Colorado Blue spruce.

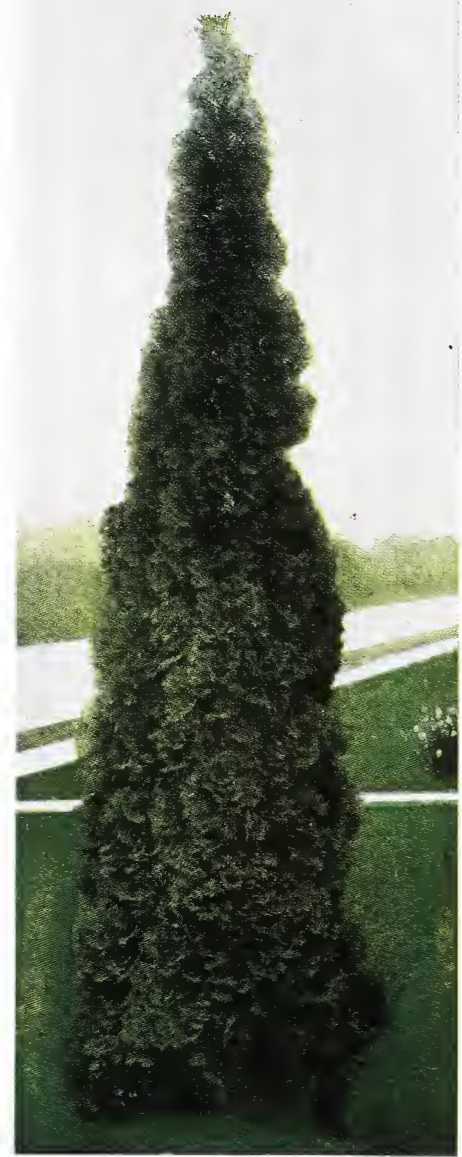

Pyramidal Arbor-Vitae.

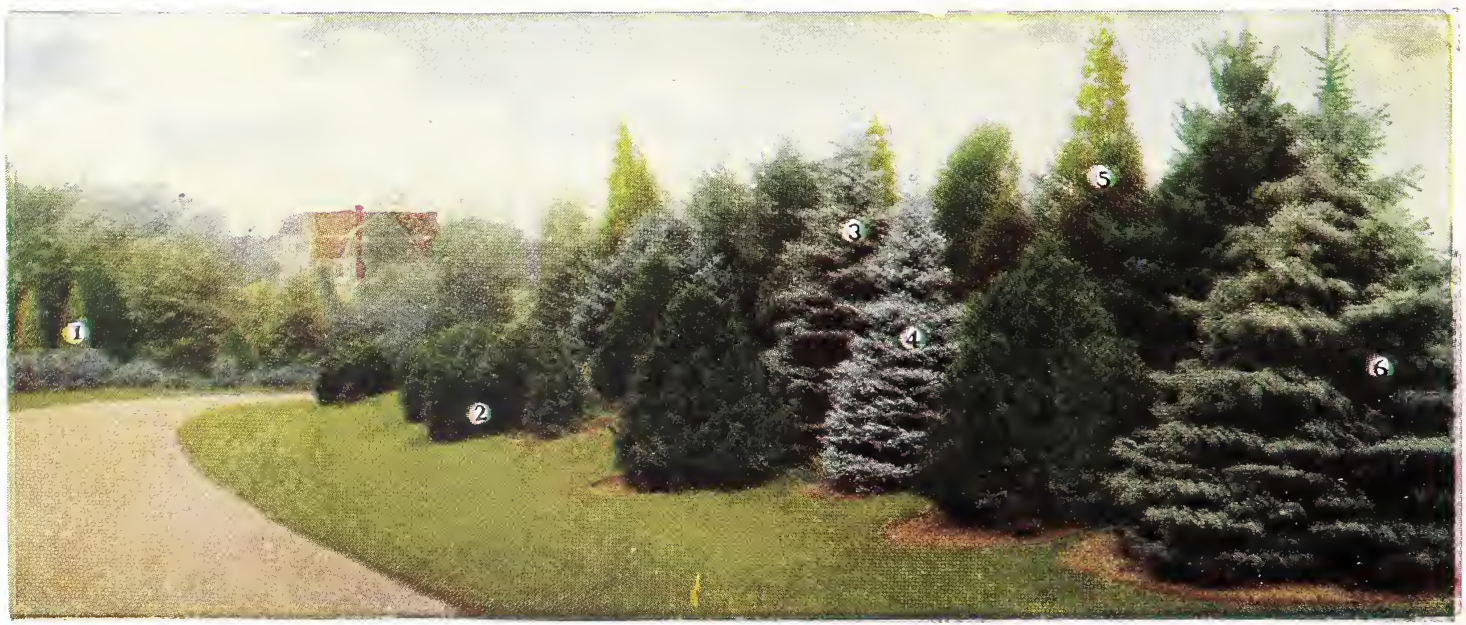

No. 1-Pyramidal Arbor-Vitae. No. "W-Mugho Pine. No. 3-Colorado Blue Spruce. No. 4-Koster's Blue spruce. No. 5-American Arbor-Vitae. No, 6-Concolor Fir. 


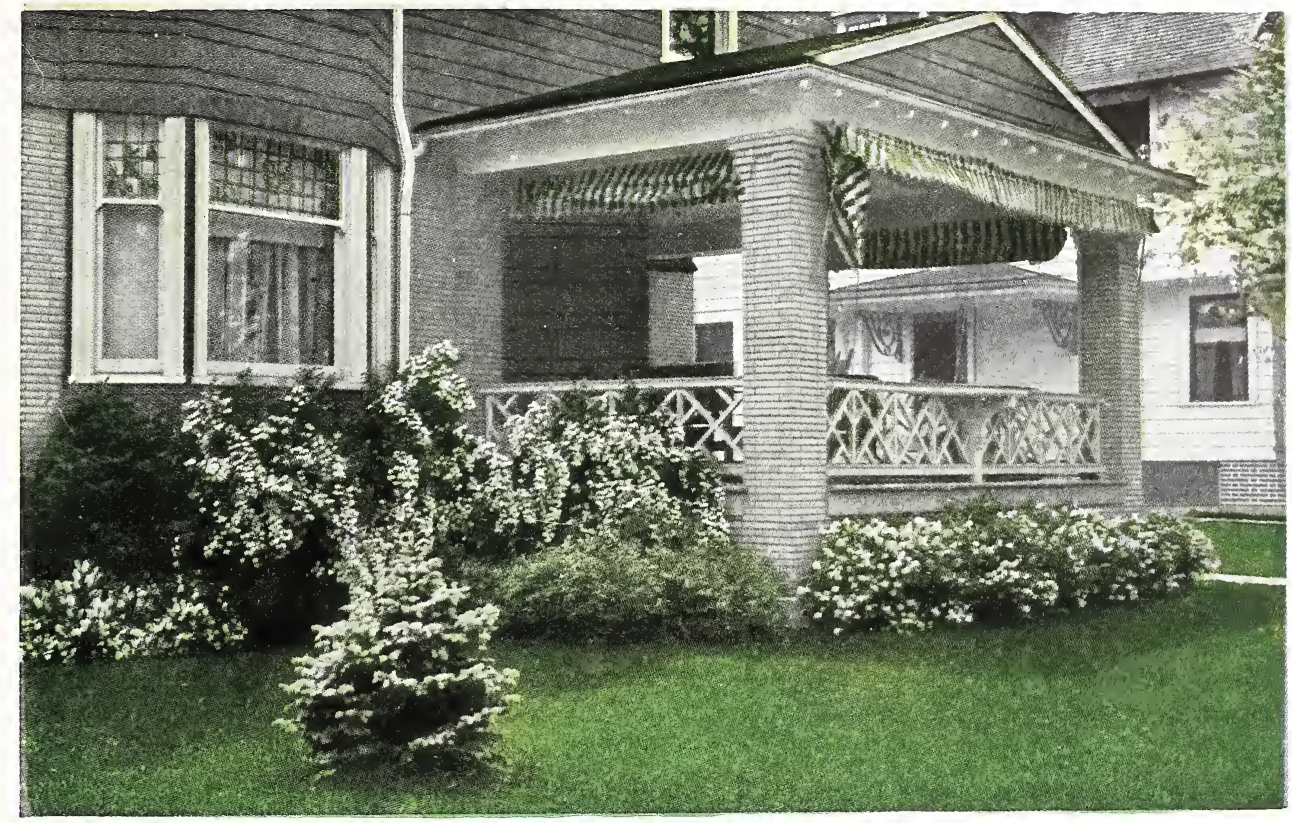

Foundation Planting, Showing Spirea Van Houttei in Corner and Dwarf Deutzia in Front of Poreh.

\section{Deciduous Flowering Shrubs}

The permanent value and beauty of Deciduous Shrubs was never better understood and appreciated than at the present time. The charm and grace they lend to the home grounds is invaluable, and, if judicious selection is made, it is possible to have a continuous succession of bloom from early in April, when the Forsythia displays its brilliant golden flowers to welcome the returning birds, to the days when the frost again nips the flowers of the very latest to bloom. In our descriptions we endeavor to indicate the height of the bush at maturity, the time of its blooming, in this latitude, and the color of its flowers.

\section{Almond - Amygdalus}

Double Red Flowered. 3 to 4 feet. A beautiful small shrub, bearing an abundance of small, double, roselike flowers in May, closely set upon twigs before the leaves appear.

Double White Flowered. 3 to 4 feet. Produces beautiful double, white flowers in May.

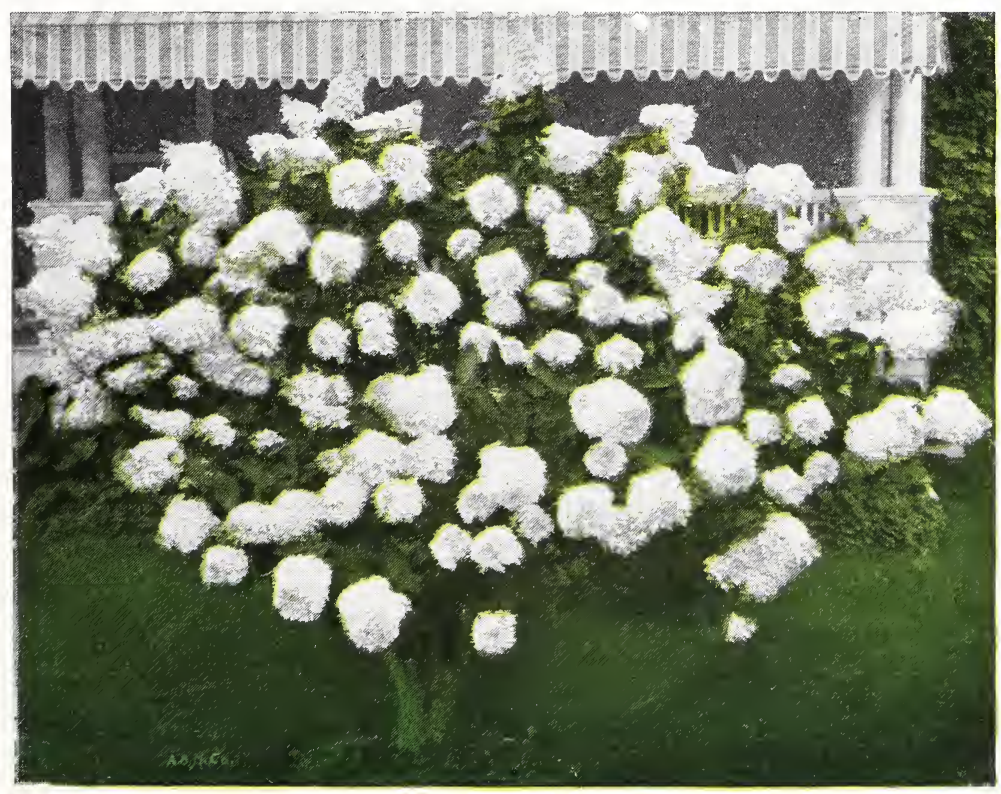

Hydrangea Paniculata Grandiflora. (See page 33).

\section{Aralia}

Pentaphylla (Acanthopanax pentaphyllum). A compact shrub, growing from 5 to 8 feet in height. Flowers greenish yellow.

Spinosa (Hercules' Club). Showy, native, with broad, handsomely cut leaves and huge clusters of small, white flowers in July. Its Winter effect is unique and handsome. Grows 10 to 15 feet.

\section{Berberis (Barberry)}

Thunberg's Barberry (Japanese). 2 to 3 feet. Of low, spreading growth, forming a dense bush. The twiggy branches are covered with small flowers succeeded by brilliant scarlet berries. The foliage takes a splendid Autumn coloring of gold and scarlet. This variety is immune to disease and does not carry rust to wheat.

Box Barberry. A dwarf, upright form of Thunberg's Barberry. Quite hardy; pleasing for low hedges or for formal garden effects. Should be planted ten inches apart. 


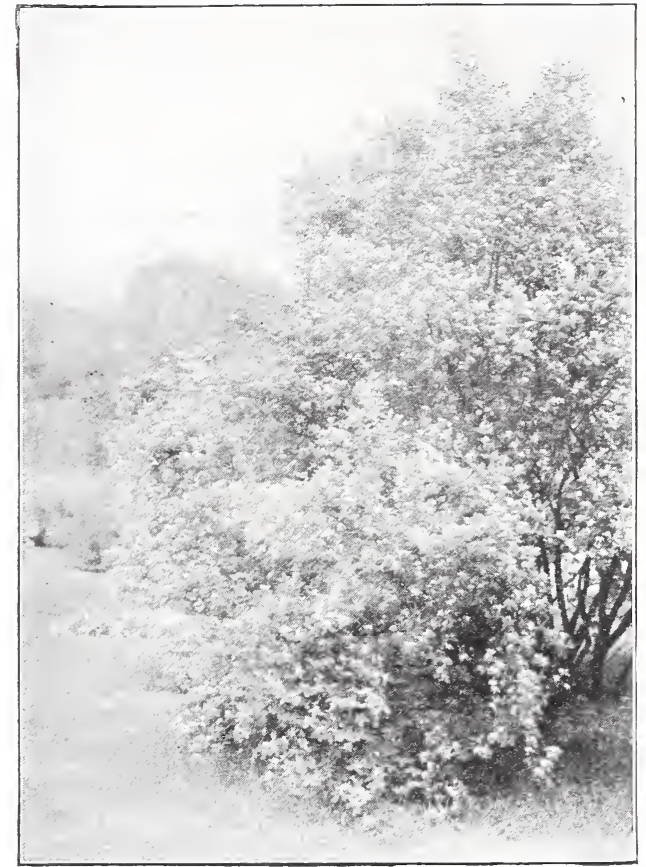

Lonicera-Bush Honeysuckle. (See page 34).

\section{Calycanthus - Sweet-Scented Shrub}

The wood is fragrant, foliage rich, flowers of a 1 are chocolate color, having a peculiar, agreeable odor. They blossom in June and at intervals afterwards. 5 to 6 feet.

\section{Cydonia (Pyrus Japonica) - Quince}

As single shrubs on the lawn they are very attractive, and for the edges of borders or groups of trees they are specially adapted.

Japan Quince. 5 to 8 feet. Has bright scarlet-crimson flowers in great profusion in the early spring.

\section{Cornus - Dogwond}

Hardy and vigorous shrubs, thriving best in moist, fertile soils. In addition to the showy flowers and fruits, which characterize most of the species, they are very attractive in Winter on account of the brilliant color of the bark of the young shoots and twigs.

Yellow Dogwood (Lutea var. flaviramea). Bright yellow bark in Winter; particularly effective in shrubberies planted with the Red Branched Dogwood.

Siberian Dogwood (Alba). Red Branched. 5 to 6 feet. A strong grower with erect and stout, bright red branches. Used for shrubbery and for Winter effects.

Variegated Leaved (Elegantissima var.) 4 to 5 feet. This variety of the well known Red Dogwood has silver margined leaves, which render it a very showy shrub. We consider it to be an addition of great merit

\section{Clethra}

White Alder or Sweet Pepper Bush (Alnifolia). 4 to 5 feet. July and August. A dense growing shrub with dark green, dentate foliage and showy, upright spikes of creamy white, very fragrant flowers. A choice plant for borders and groups. Very desirable on account of its late blooming season.

\section{Cotoneaster}

Acutifolia. A dense growing shrub with dark green, glossy, oval leaves. The best hedge plant for the Northwest. Perfectly hardy and resembles privet. We are offering this for the first time, having a few thousand plants that are ready for planting and predict it is the coming hedge plant where privet is not hardy.

\section{Deutzia}

The showy flowers and ease of culture make the Deutzia extremely popular for the shrub border. It will grow in almost any well drained soil but should not be planted north or in exposed positions; frequently used in combination with Philadelphus, Spirea and Forsythia, for mass planting.

Gracilis. A neat, dense little bush, rarely over 2 feet high, that blooms in May, wreathing its drooping branches with pure white flowers. Equally valuable for shrubberies and forcing.

Lemoinei. The branches are entirely covered with erect panicles of large, snow-white flowers, quite distinct from all other Deutzias, and one of the best varieties. Hardy.

\section{Elaeagnus - Oleaster}

Russian Olive (Angustifolia). A very hardy and handsome species that in some sections forms a small tree, 12 to 15 feet high. The leaves are particularly handsome, willow-like, and a rich silvery white. The flowers are cmall, golden yellow and very fragrant, followed by yellow fruits, which are covered with silvery scales. Blooms in June.

\section{Euonymus}

\section{Strawberry or Spindle Tree}

Cork Barked Euonymus (Alatus). Of dwarf. compact habit; branches four-winged; leaves small; fruit red. One of the most beautiful of shrubs in Fall when foliage turns bright scarlet.

Burning Bush; Wahoo (Atropurpureus). 6 to 10 feet. Tall growing native shrub with leaves larger than the European, that turn scarlet in Autumn. Its most attractive feature is the abundance of bright red berries that are carried well into the Winter.

\section{Forsythia - Golden Bell}

The Forsythias are among the very earliest shrubs to bloom, and before the snow is completely gone they give signs of awakening life. They are strong, vigorous shrubs with many branches, which become clothed with beautiful, bright golden yellow flowers before the leaves appear.

Aurea. Handsome form with drooping branches. Flowers yellow. Foliage golden colored. Very similar to Forsythia Fortunei, with the exception of colored foliage. Grows 6 to 7 feet high.

Fortune's (Fortunei). A handsome form. with slightly drooping branches. Flowers golden yellow, often with twisted petals. A grand shrub, often 5 to 7 feet tall.

Intermedia. Flowers bright golden yellow: foliage glossy green; resembles the Viridissima, but hardier; a valuable variety.

Suspensa. Long, slender, curving branches. May well be called Weeping Forsythia. 


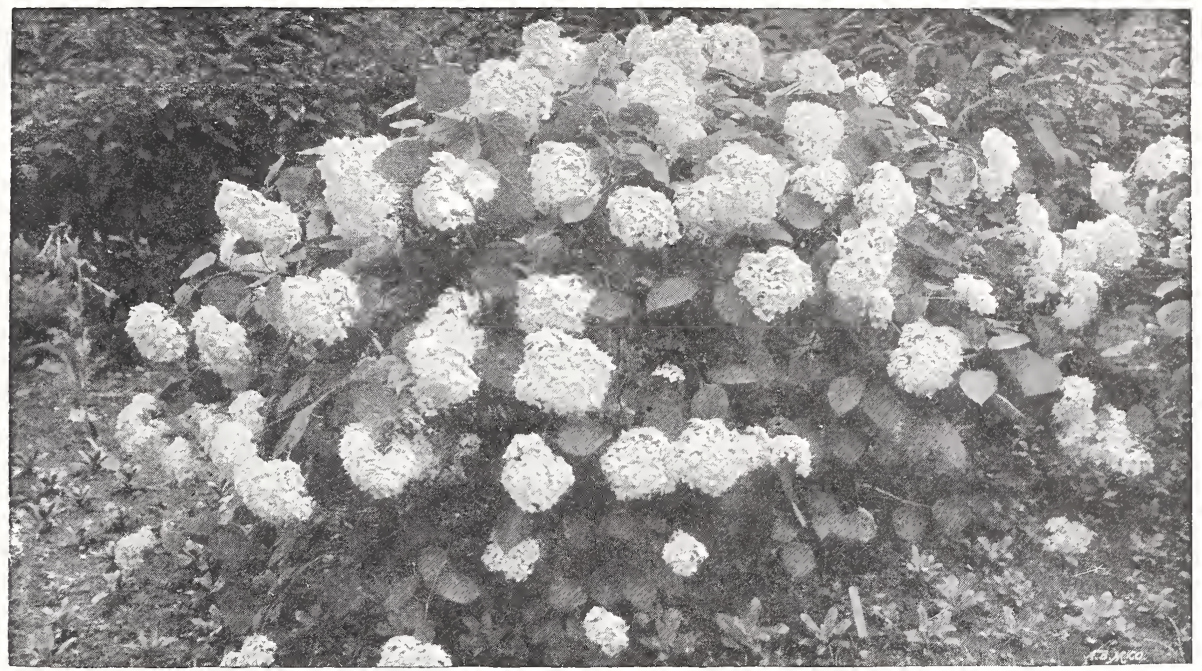

Hydrangea Arborescens Sterilis-Hills of Snow.

\section{Fringe - Rhus}

Purple Fringe (Cotinus). A unique and conspicuous spreading shrub or small tree, 10 to 12 feet high, with large leaves. These are overhung in midsummer by cloudlike masses of very light, mistlike flowers, having the appearance of smoke at a little distance.

\section{Hibiscus - Althea or Rose of Sharon}

Althea. One of the best known shrubs, with handsome plain and variegated foliage and bearing large single or double flowers in August and September when the shrubbery border is apt to be bare of other flowers. They are very hardy, easily cultivated and will bloom until their growth is cut off by frost; they are

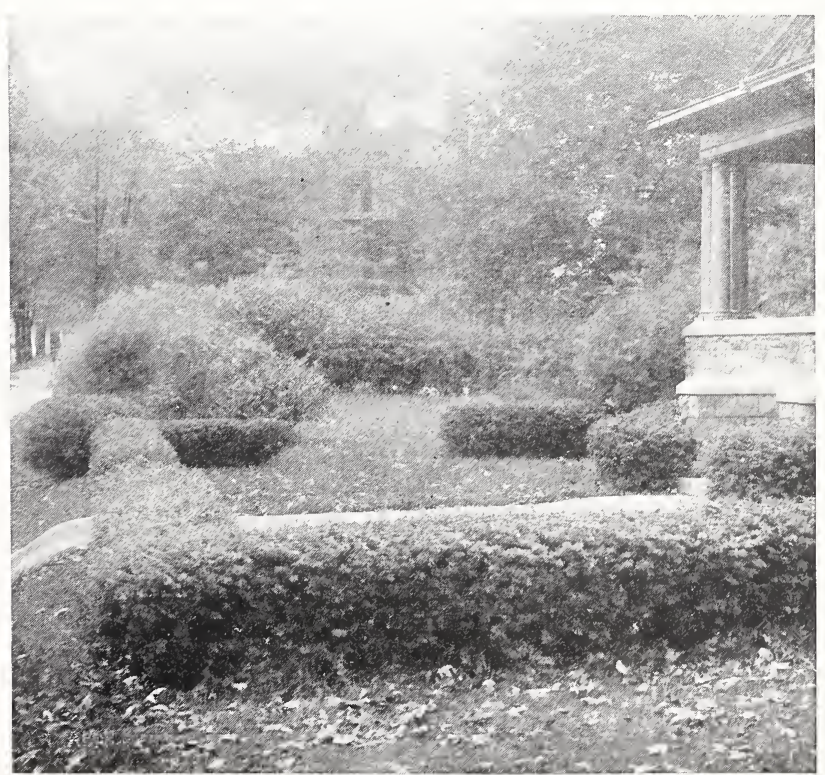

Thunberg's Barberry. (See page 31). fine for flowering hedges, and will stand considerable pruning. This should be given in Winter. They attain a height of from 6 to 10 feet. We can supply it in white, pink, purple or red. Not very hardy in Wisconsin.

\section{Hydrangea}

Grand, free flowering shrubs with large clusters or panicles of showy flowers. They are admirably adapted for border planting, either as specimen plants or in masses. A moist, fertile soil, with full or partial exposure to sun, is best adapted to their requirements.

Bush Hydrangea (Paniculata grandiflora). 5 to 6 feet. This is one of the most valuable hardy shrubs. It is perfectly hardy in all parts of the country. The flowers are white, borne in immense panicles nearly a foot in length. It commences flowering in July and continues until November. The plant should be cut back every Spring at least one-half of last season's growth, as the flowers are borne on new wood and are much finer when the plant is treated this way. An excellent shrub for cemetery planting.

Arborescens (Hills of Snow). 4 to 6 feet. This hardy American shrub is the very finest addition to this class of plants found in many a year. The blooms are of the very largest size, of pure snow-white color, and the foliage is finely finished. One of its most valuable characteristics is its coming into bloom just after the passing of all the early spring shrubs, while its long season of bloom, from early June through August, renders it doubly valuable. Hardy.

Tree IIydrangea (Paniculata grandiflora). 6 to 8 feet. In tree form. Beautiful as a shrub, they are grandly beautiful as a tree, growing in loveliness as they acquire age and size. 


\section{Ligustrum - Privet}

The Privets are best known for their use as hedge plants, but if allowed to grow to full height, they bear beautiful clusters of white flowers very much like a small lilac in character. All the varieties stand pruning to any extent and can be cut into any desired shape or form. In severe Winters the tops kill back in this latitude, but soon recover.

Amoor (North). A fine shrub of upright growth. Its pure white flowers appear in June and are followed by bluish black seeds.

Regel's. A fine, hardy variety, desirable in growing singly as specimen or in mass planting. This is one of the berry varieties.

\section{Lonicera $-{ }_{\mathrm{g}}^{\mathrm{B}} \mathrm{Bush}$ Họneysuckle}

The following species and varieties are of erect, shrubby habit. Valuable for their handsome flowers and showy fruit. The climbing sorts will be found under the head of Climbing Shrubs.

Bella albida (Bella Honeysuckle). A handsome hybrid of strong growth. White flowers are borne in great clusters, followed by attractive ropes of red berries which remain all Summer. An excellent shrub for mass planting. 6 to 8 feet.

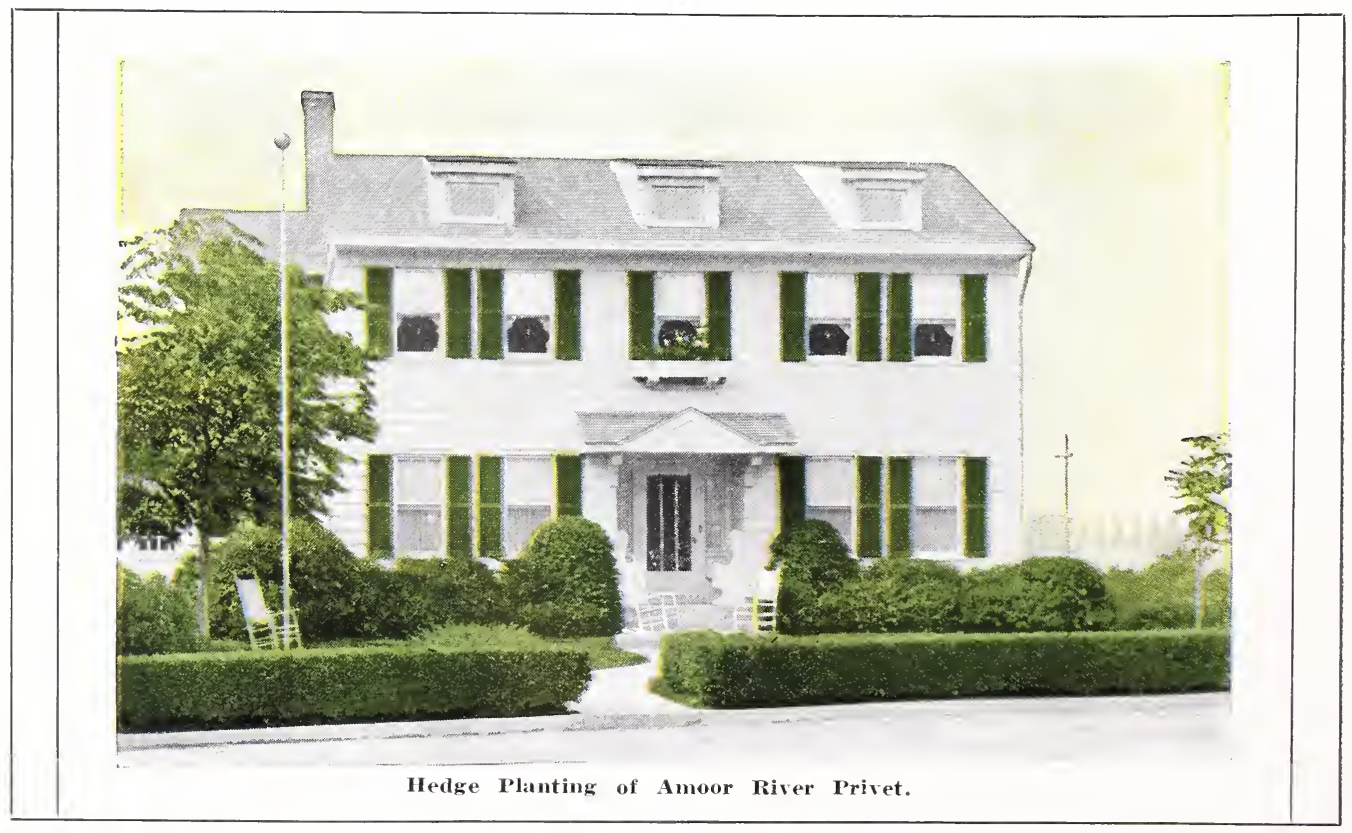




\section{Lilac - Syringa}

Hardy free flowering shrubs with showy, fragrant flowers in Spring and early Summer. They are among the most popular and beautiful of flowering plants, and thrive in almost any fertile soil with moderate moisture. A careful selection will offer a greatly extended season of blooming.

Common Purple Lilac (Vulgaris). 8 to 10 feet. This is the oldest and best known type of the Lilac. From it have sprung most of the hybrids and seedling varieties which have made the Lilacs as a class, one of our most popular modern shrubs.

Common White Lilac (Alba). The well known whiteflowering form of the above.

Persian Lilac (Persica). 5 to 6 feet. May and June. A distinct species of rather smaller growth than Vulgaris. The branches are slender and straight with smaller and narrower leaves. The bright purple flowers are borne in loose panicles. A very graceful form.

Villosa. A species from Japan. Large branching panicles: flowers light purple in bud, white when open; fragrant. Especially valuable, as its flowers appear two weeks after those of other Lilacs.

\section{Named French Lilacs}

The named sorts are much superior to the old type of Common Purple and White, and they bloom when plants are much younger. 6 to 8 feet.

Chas. Joly. Double flowering. Has dark wine colored blossoms with silvery reverse.

Chas. X. of exceptionally strong, rapid growth, with large, shining leaves and rather loose trusses of reddish purple flowers. Single.

Lemoinei. A choice variety of the Lilac, producing long racemes of double, purple flowers, lasting longer than the single sorts. A valuable acquisition.

Ludwig Spaeth. Dark purplish red flowers, large, and in long panicles. A distinct, superb sort that will give great satisfaction. Double flowering.

Mad. Abel Chateney. A very desirable variety, with milkwhite, double flowers; panicles of medium size; very compact; fine for cut flowers.

Madame Casimir-Perier. White flowers in large, graceful panicles. A profuse bloomer. One of the very best sorts. Double flowering.

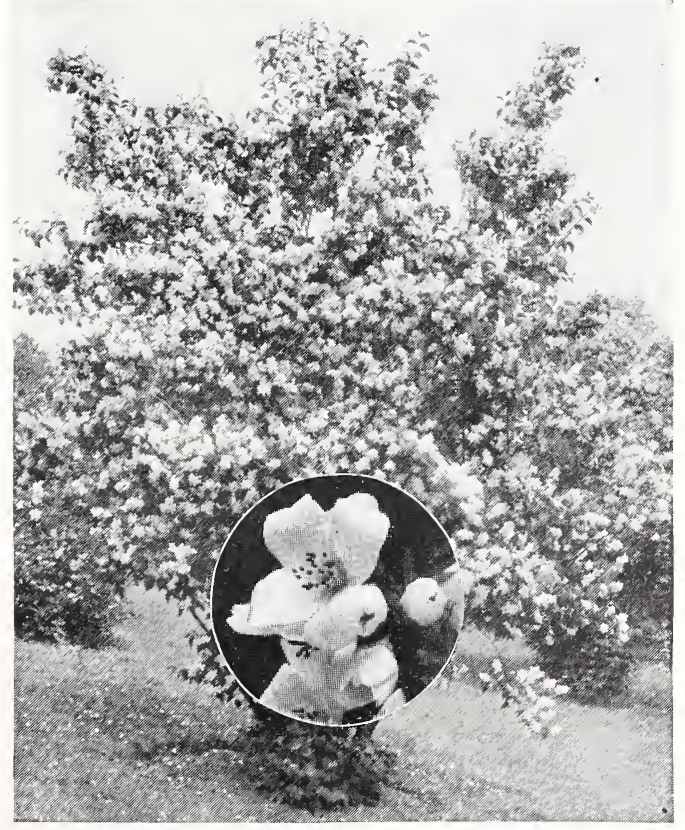

Philadelphus Virginal (See page 36 ).

Marie Legraye. Large panicles of white flowers: the finest white.

Michael Buchner. Clear lilac; double; pale lilac.

President Grevy. Large, beautiful blue flower panicles. Individual flowers very double and large. Ore of the best.

\section{Philadelphus - Syringa}

Also known as Mock Orange. Of vigorous habit, very hardy, with large, handsome foliage and beautiful white flowers produced in great profusion. They merit a place in every collection of shrubbery.

Aureus (Golden Syringa). 3 to 5 feet. A compact shrub with bright yellow foliage which retains its color well throughout the season. Very effective in grouping as a contrast to the darker foliage of others.

Coronarius (Sweet Syringa) 8 to 12 feet. June. The old and well known Mock Orange. A graceful, upright bush with long branches covered with dark green foliage. In June completely covered with showy pure white flowers of the most delightful fragrance. Probably the most fragrant of the class. 


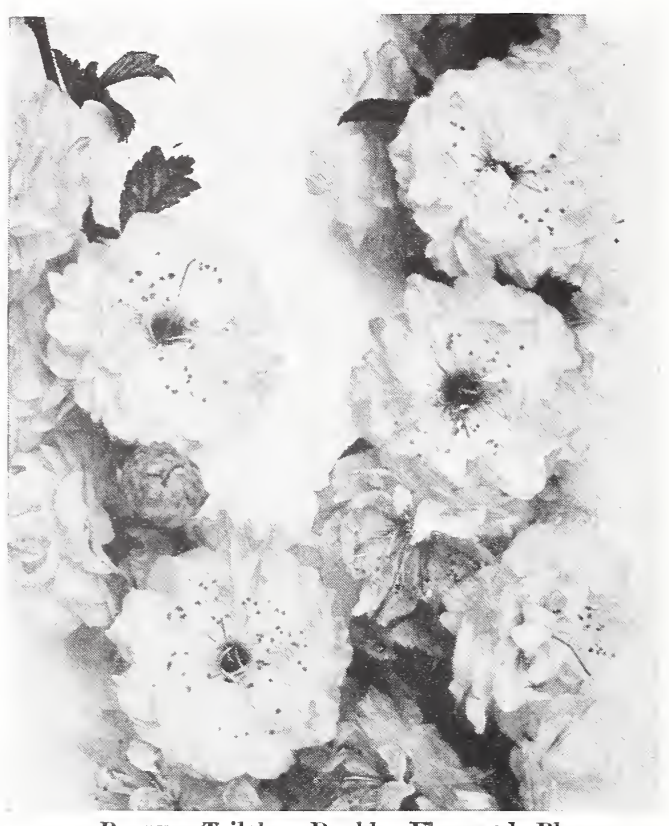

Prunus Triloba-Double Flowered Plum.

PHILADELPHC-Continued.

Grandiflora (Large Flowered Syringa). \& to 12 feet. June. Very showy, large flowers. usually borne in threes. Scentless. It is of rapid growth with reddish bark.

Lemoine. A small shrub ralely attainin? a height of more than four feet. Branches slender and bearing in June a profusion of flowers closely resembling the orange blossoms in size, form and fragrance, which is very desirable.

Virginal. A magnificent new variety. The bush grows moderately tall, with good foliage and ccmpact habit. The flowers are the largest, handsomest, and most sweetly fragrant of any known variety, with longest blooming season. Grows 5 to 6 feet.

\section{Prunus - Flowering Plum}

Purple Leaved Plum (Othello). 8 to $10 \mathrm{feet}$ A small tree or shrub. The foliage and young shoots are of a rich reddish purple, which they retain throughout the season. Not perfectly hardy in this latitude.

Double Flowering Plum (Triloba). 5 to 8 feet. A large shrub or small tree; the branches are covered early in the season, before leaves appear, with small, double, pink flowers. Very desirable.

\section{Rhamnus - Buckthorn}

Common Buckthorn (Catharticus). 4 to 6 feet. June-July. One of the best plants for ornamental hedges. The ovate, dark green leaves are attractive throughout the season. Flowers small and inconspicuous. Branches are thorny. It stands shearing well and is easily trimmed to any desired height and form.

\section{Rhodotypos - White Kerria}

Bears an abundance of white flowers in May; foliage attractive; bush slender grower; hardy. 3 to 6 feet.

\section{Ribes - Flowering Currant}

Alpinum (European Mountain Currant). 3 feet. Of dwarf, compact habit, growing very symmetrical, with fragrant yellow flowers.

\section{Rhus - Sumac}

Smooth Sumac (Glabra). 8 feet. Largegrowing shrub, with smooth bark. Very effective in Autumn with its crimson seeds and foliage.

Cut Leaf Sumac (Laciniata). 6 to 8 feet. An ornamental variety similar to glabra, but has its leaves deeply cut, giving it a fernlike appearance.

Staghorn Sumac (Typhina). 8 to 12 feet. A dense, relvety, hairy species. In Fall it has brilliant foliage and scarlet heads of fruit. Thrives in poor, rocky soil.

\section{Sambucus - Elder}

Common Elder (Canadensis). 8 to 12 feet. A large, spreading bush with handsome foliage. The white flowers in June and July are borne in flat cymes. They are followed by black fruits in August and September.

Cut Leaved EIder (Laciniata). 5 to 9 feet. A valuable variety with elegantly divided leaves. of drooping habit and one of the handsomest shrubs in cultivation.

Golden Elder (Aurea). Bright golden yellow leares, the color being distinct and permanent all summer. Of vigorous, spreading habit. One of the best golden foliaged shrubs.

\section{Spirea}

The Spireas are all elegant, low shrubs, it the easiest culture, and their blooming extend. over a period of three months.

Inthony Watefer (Bumalda). This variety has largely superseded its parent. It produces flowers of a bright crimson and blooms so freely that it may be kept in flower throughout the Summer till late Fall by trimming out dead bloom.

Arguta. 3 feet. May. Japan. Of light open habit, with small deep green foliage. When in bloom, each branch is completely covered with a wealth of minute, pure white flowers.

Billiardi (Billiard's Spirea). 4 feet. JulyAugust. A strong grower with dull green foliage and dense panicles of bright pink flowers. Also blooms occasionally during the Fall.

Callosa alba (Fortune's Dwarf White Spirea). 2 feet. Blooms all Summer. A pure white form.

Froebeli. Has a flat pink blossom, very similar to Anthony Waterer. It resembles this variety in every respect except that it is a little stronger grower. Perfectly hardy and deserves extensive planting.

Opulifolia var. aurea (Golden spirea or Golden Leaved Nine Bark). 5 to 8 feet. Foliage is of a bright golden color and finely shaded. This is one of the finest golden leaved shrubs and a very desirable variety for the contrast it offers.

Sorbifolia. Long, showy panicles of white flowers. A fine Spirea. 6 to 7 feet.

Thunbergi (Thunberg's Spirea). 3 to 4 feet. May. One of the finest Spring blooming small shrubs. The flowers are pure white and are borne along the entire length of the branches.

Van Houttei. A beautiful shrub, growing 4 to 6 feet. Blossoms in clusters about $1 \frac{1}{2}$ to 2 inches in diameter; flowers white and borne in great profusion, frequently covering the plant when in bloom. It is one of the finest shrubs we have for cemetery use, and also makes a beautiful ornamental hedge. It is perfectly hardy as far north as Northern Minnesota. 


\section{Symphoricarpos - Snowberiy}

Snowberry (Racemosus). 3 to 4 feet Inconspicuous rose colored flowers in June and July, followed by large, clustered, milk-white fruits which remain far into the Winter.

Indian Currant (Vulgaris). 3 to 4 feet. Similar to the Snowberry except that its fruits are red, and that the smaller rod berries cluster in thick ropes about the weighted down stems.

\section{Tamarix}

Amurense (Asiatic Tamarisk). New. The hardiest of its species; found in Asia. Other varieties are often tender in this locality. The loose, rose colored flowers are borne along its branches; the foliage is light and feathery. If cut back each Spring before the growth starts, the bush will be more graceful during the season. May be planted on moist grounds as well as dry. Grows 5 to 6 feet.

Hispida. A new variety of recent introduction; perfectly hardy, coming throtugh our severe Winter of 1911-12 without injury. Similar to Amurense, but the leaves are more compact and have a bluish tint and has an immense head of flowers of the brightest carmine-pink. This shrub is a great acquisition to the Tamarisk family.

\section{Viburnum - Snowball}

This is a showy group of shrubs that usually grow from 5 to 10 feet high, bloom lavishly in Spring, bear pretty fruits and color to red or purple in Fall.

High Bush Cranberry (Opulus). The well known variety in old gardens. Grows 8 to 10 feet high, bearing its balls of flowers in great profusion in May, followed by scarlet fruits.

Common Snowball (Sterile). 4 to 5 feet. A grand hardy shrub. The flowers appear in numerous compact balls in spring. Well known and justly popular.

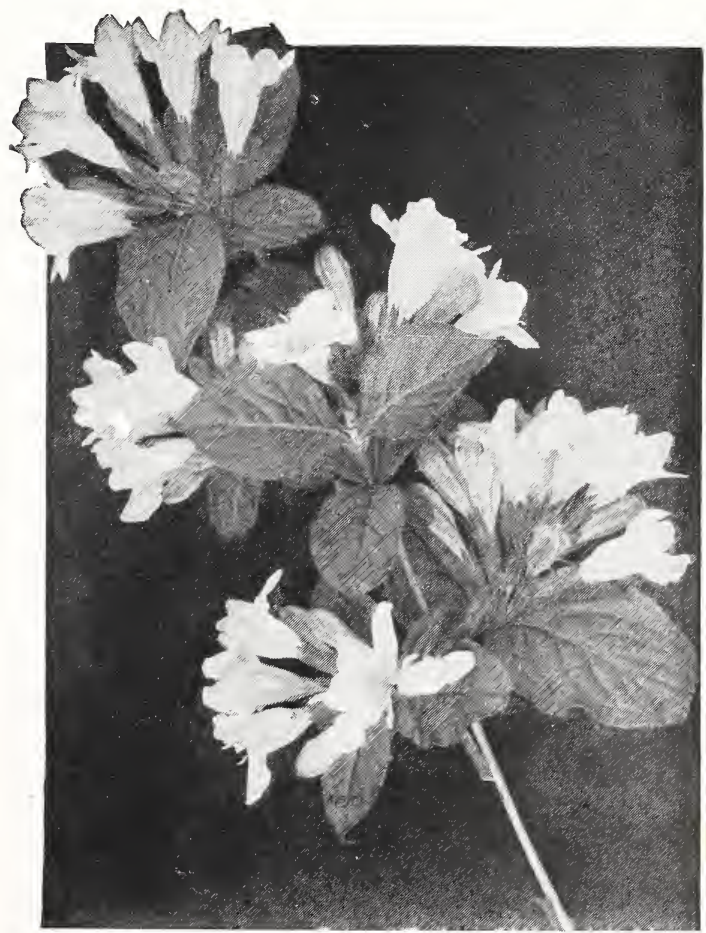

Diervilla-Weigela Rosea.

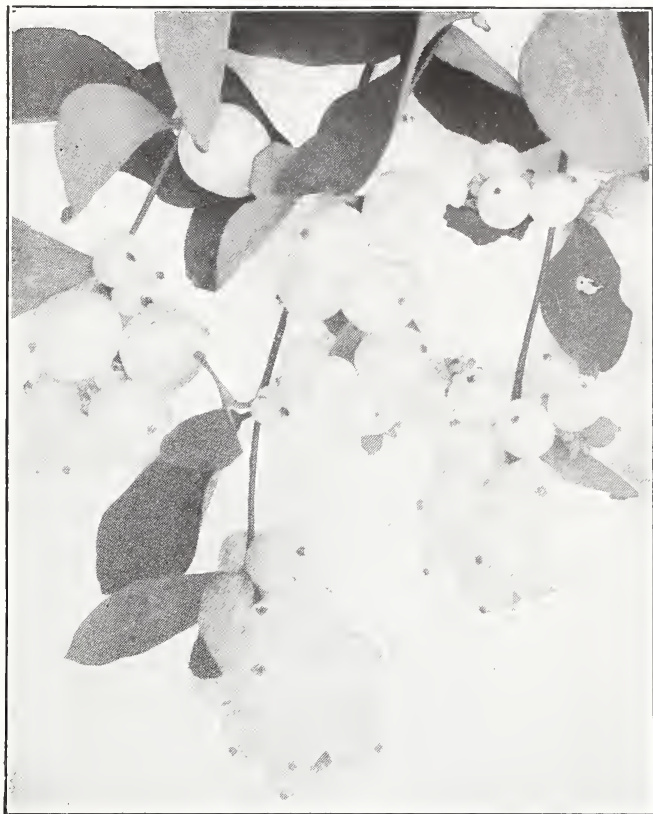

Symphoricarpos Racemosus-Snowberry.

Dentatum. 6 feet. A bushy, upright-growing shrub of large size, growing to perfection in all sections of the North. The leaves are heart-shaped, bright green in Summer, changing later to rich purple and red. The creamy white, handsome flowers, borne in late Spring, in large, flat clusters, are followed by blueblack berries.

Japan Snowball (Plicatum). 3 to 4 feet. A handsome shrub with branches at right angles to the stem, and beautifully creased foliage. Its white flowers are borne the entire length of the branches, creating a most ornamental effect.

Lantana (Wayfaring Tree). 5 to 6 feet. A tall shrub with white flowers in large clusters in May, succeeded by bright red berries changing to black later.

Lentago (Sheepberry). A large-growing shrub; leaves bronze when young, glossy green in midsummer, and brilliant orange and red in Autumn. Flowers creamy white, with dark blue berries in Autumn on red stems. 10 to 12 feet.

\section{Weigela - Diervilla}

Candida. 6 feet. This is the very best of all the white flowering Weigelas. A strong, upright, erect grower; flowers pure white and produced in great profusion in June and continues to bloom through the Summer.

Eva Rathke. 5 to 6 feet. A charming new Weigela; flower brilliant crimson; a beautiful, distinct, clear shade, producing two and sometimes three crops of blossoms in a season.

Rosea (Rose Colored). 5 to 6 feet. A hardy and beautiful shrub, bearing in May a profusion of rose colored flowers. Introduced from China, and justly considered one of the finest shrubs we have.

Variegata. An attractive, dwarf-growing shrub, with handsomely variegated leaves and flowers of a very pale pink, almost white. 2 to 3 feet. 


\section{Roses}

The Rose, "The Queen of Flowers," is justly one of the most popular in cultivation, and none gives better satisfaction to the lover of beautiful flowers when properly treated. To obtain richness and luxuriance of foliage, and well developed flowers, it must receive good cultivation. With good treatment it will yield a varied, profuse and beautiful display of flowers from June to November.

Our Roses are strong, dormant plants grown outdoors, well rooted and in every way first class. They have in some cases already bloomed before being sent out and we believe will give satisfaction and permanent success.

They thrive best in a good, well drained clay soil where they can have plenty of sunlight. Make the ground rich with well-rotted manure, and in Sprino severely prune all varieties except climbers and Persian Yellow. Cover in Fall with some coarse, dry materials.

Pruning is necessary to maintain a good shape, and to secure a good supply of young wood. This should be done in the Spring; the latter part of March is the best time. This is done bv cutting off the previous vear's growth to within three or four buds. The remaining buds will then throw out vigorous branches. and in due season produce a splendid bloom. This mode of pruning, however, is not applicable to climbing Roses until the desired surface or space is covered.

INSFCTS-GUARANTEED REMEDIES

Roses which are strong and vigorous are not likely to be attacked by insects, or, if attacked, are not easily injured. It is highlv important, therefore, to $\mathrm{k}$ e e p y ur plants healthy and in good growing condition by liberal manuring and thorough cultivation. When insects appear, apply the proper remedies promptly and vigorously, and in bad attacks stir the ground deeply with the hoe and rake every day. A little perseverance to resist the -resent attack is all that is needed; next year you may not be troubled with insects at all. We find that a strong stream of water from a hose applied once a day, either morning or night, will keep our Roses free from insects. Where this is impossible, we would suggest the following remedies:

Boil for ten minutes four ounces of quassia chips in a gallon of soft water. Strain off the chips and add four ounces of whale-oil soap, which should be dissolved in it as it cools. Stir well before using. Apply with a clean painter's brush of moderate or small size, brushing every leaf and shoot that is infested. After fifteen or twenty minutes the plants should be washed or syringed with pure water. For mildew, sprinkle lightly with lour of sulphur.

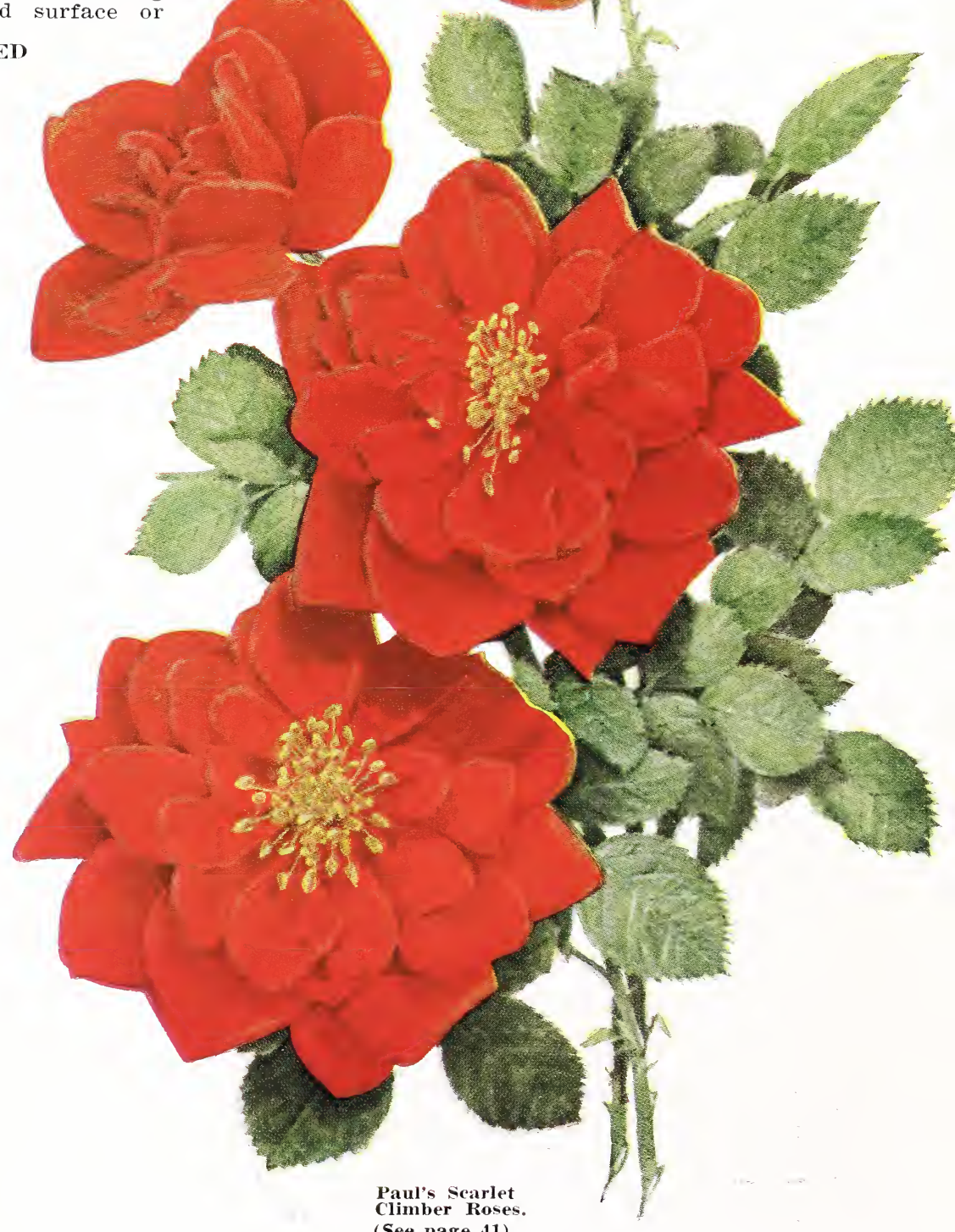

Climber Roses.

(See page 41 ) 


\section{ROSES-Continued.}

General Jacqueminot. Very fragrant; not very full, but large and effective. One of our best garden Roses.

General Washington. Deep crimson; very large and double; open flat.

Gruss an Teplitz. Double red. Very free bloomer. Beals more red Roses than any other variety known.

Hermosa. An old farorite that is always in bloom; flowers cupped, daintily formed and rery fragrant. Bright pink.

J. B. Clark. Hardy; deep scarlet, shaded dark crimson; wondelfully strong and upright grower; heary dark green foliage; flowers very large, full and double; very fragrant.

John Hopper. Flowers brilliant rose, large, very regular and full; very sweet.

Jules Maroottin. Bright cherry-red; large, full and rery fragrant.

La France. Delicate, silvery pink; large and very double; very fragrant and a constant bloomer. Semi-hardy.

Marshall P. Wilder. (See color engraving on page 39 ). Bright cherry-red; of good size; very fragrant and perfectly double. Plant is a vigorous grower and continues long in bloom. One of the very best.

Mrs. John Laing. Pink, large, fine form, strong stems, fragrant. Profuse bloomer.

Magna Charta. A bright clear pink; very sweet; large, fine form; double; free bloomer.

Margaret Dickson. A very free grower, foliage large and dark. Flowers white, with pale flesh center; petals are thick and bell-shaped; quite fragrant; a fine sort.

Madam Gabriel Luizet. Hardy; light, silvery pink; cup-shaped; very large, slightly fragrant free blooming.

Madame Plantier. Pure white, above medium size, produced in great abundance early in the season. One of the best hardy white Roses

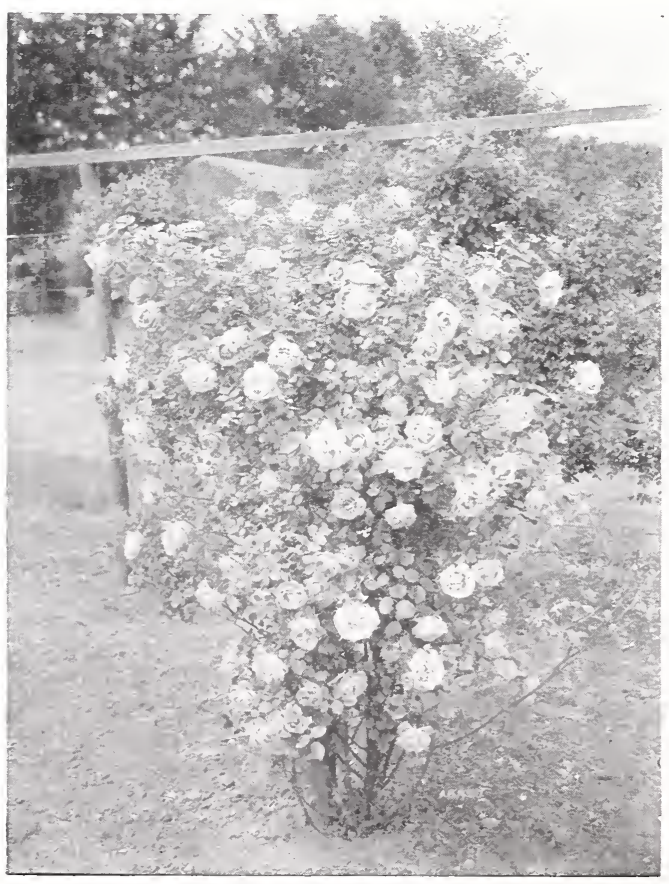

Climbing American Beauty Roses.

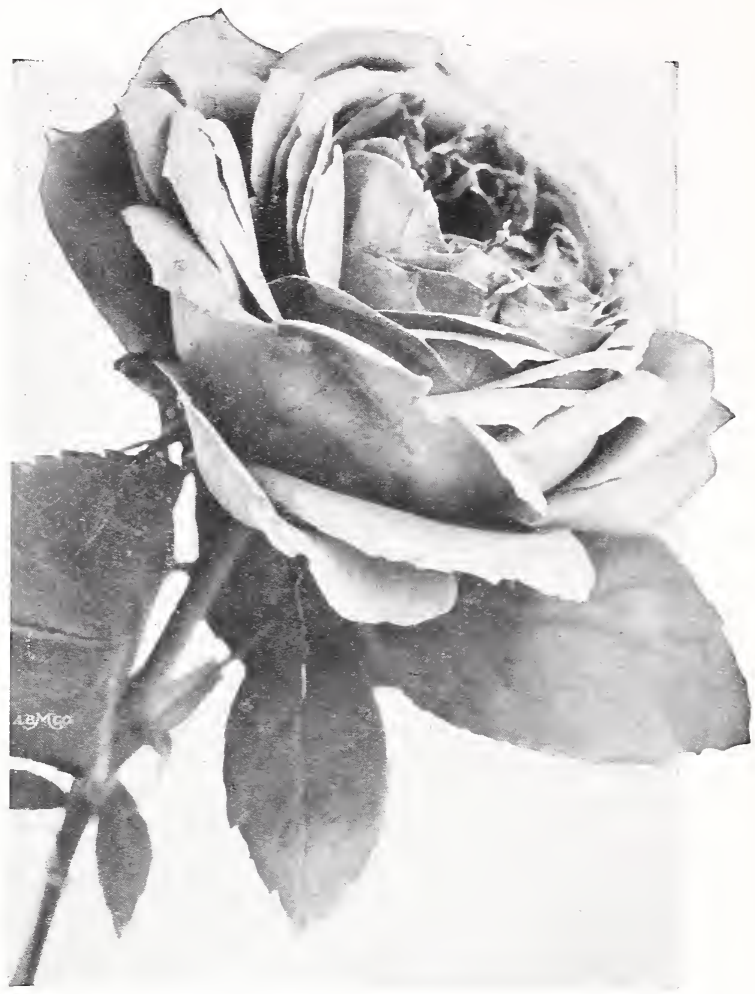

General Jacqueminot Rose.

Prince Camille de Rohan. Deep relvety crimson; large, moderately full.

Paul Nerron. The largest variety in cultivation. Deep rose color; very full and double. Finely scented, good foliage and free bloomer.

Soleil d'Or (New), (See color engraving on page 39 ). This new yellow Rose comes very highly recommended. The flower is full, large, slobular-shaped, yellow shaded with red. A vigorous grower and free bloomer.

Ulrich Brummer. Flowers brilliant cherryred, large and full, with exceedingly large, shell-shaped petals. A continuous bloomer.

\section{Climbing Roses}

These, for their hardiness and profusion of flowers, recommend themselves to all lorers of the beautiful. They are admirably adapted to cover arbors, walls, and any unsightly objects, and are always ornamental in any situation.

Crimson Rambler. Introduced from Japan in 1893 , it has been a source of wonder and admiration wherever exhibited. The plant is a very vigorous grower, making shoots from 8 to 15 feet in a season.

Climbing American Beauty. Color rosy crimson, similar to its pollen parent; flower about four inches in diameter, finely formed on long stems. Blooms very freely in May and June, and occasionally during the summer.

Dorothy Perkins. One of the grandest Roses yet produced; the beautiful, double, shell-pink flowers come in clusters in great profusion, making a wonderful display; foliage finer, smoother and darker than Crimson Rambler. 


\section{ROSES-Continued.}

Dr. Van Fleet. Probably the best Climbing Rose in cultivation. Perfectly formed, longpointed, deep pink buds on long stems with several in a cluster, that open a lighter shade of pink, expanding to about 4 inches. It is a vigorous grower, with abundant dark green, glossy disease-resistant foliage that is a delight to the eye all Summer.

Excelsa (Red Dorothy Perkins). A radiant, blood-red cluster rose, as free and double as Dorothy Perkins of which it is the red prototype. The clusters are very large.

Flower of Fairfield (Everblooming Crimson Rambler). A sport or offspring of the popular Crimson Rambler. It surpasses any other Rose for brilliancy of display. Blooming in the early Spring, it continues until well along in the Autumn, bearing large, brilliant crimson clusters of flowers with the greatest freedom.

Paul's Scarlet Climber. (See color engraving on page 38 ). The brightest and purest red of all pillar Roses. Vivid scarlet shaded crimson, semi-double flowers in clusters, that retain their color till they fall, never turning blue, the color being intensified by the numerous yellow stamens. A vigorous grower with a profusion of bloom that remains for a long season.

Prairie Queen. Rosy red; flowers large and compact. Very popular.

Seven Sisters. Crimson, changing all shades to white.

Silver Moon. One of the most satisfactory and indispensable climbing Roses. This extraordinary climber is covered with rich, dark green foliage, a fitting background for the large. semi-double, white and creamy flowers, often 4 inches in diameter, that are borne in great profusion.

White Dorothy Perkins. Of the same habit of growth as the Dorothy Perkins. Where a white Rambler is wanted, we recommend this variety.

Wichuraiana or Memorial Rose (Japanese Trailing Rose). A distinct and valuable variety from Japan; it is a low-trailing species, its stems creeping on the earth almost as closely as the ivy. The flowers are produced in the rreatest profusion in clusters on the end of every branch, after the June Roses are past. Pure white.

Yellow Rambler (Aglaia). The color is a decided yellow; the flowers are very sweet scented; habit of growth is very vigorous. well established plants often making shoots from 8 to 10 feet in height in a single season.

Tausendschoen. Introduced from Germany very recently, it has become very popular. It has the same vigorous habit of growth as the Ramblers, attaining ten feet a season. Almost devoid of thorns. The flowers are of a soft pink when first opening, changing to a carminerose on the reverse as they fully expand.

\section{Miscellaneous Roses}

Baby Rambler, Pink (Anny Muller). Large clusters of brilliant rose colored flowers in great profusion. A splendid bedding variety. Blooms all season until buds are killed by severe frost.

Baby Rambler, White. Flowers are borne in clusters of 50 to 75 individual flowers; foliage glossy and finely cut; vigorous, hardy and free blooming. A fine bedding variety.

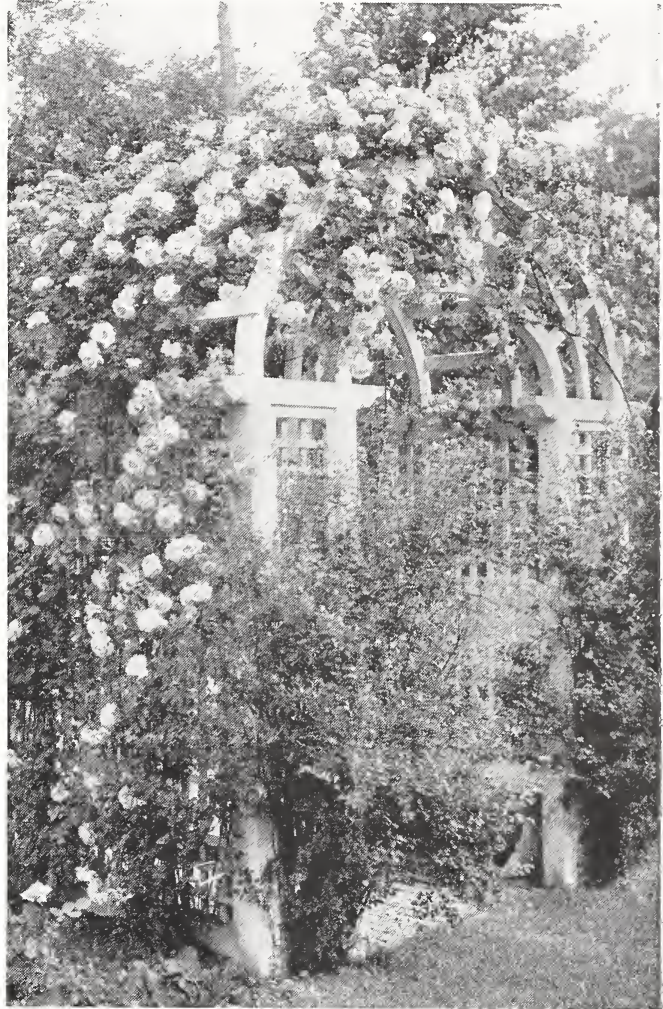

Dr. Van Fleet Roses.

Baby Rambler, Red (Madame Norbert Levavasseur). A dwarf form of the widely known and popular climbing Rose, Crimson Rambler, being hardy, vigorous and perpetual flowering. The flowers are well formed, of a crimson-red color, and borne in clusters. For growing in pots in the house, or as a bedding variety, it will be found invaluable. Blooms continuously.

Harison's Yellow. Perfectly hardy; semidouble; blooms early.

Persian Yellow. Flowers double and full; deep golden color; bloons freely in June. Finest hardy yellow rose grown.

\section{Moss Roses}

The Moss Roses are favorites with everyone, on account of the beautiful buds, which for bouquets and cut flowers are invaluable.

Blinche Morcau. Pure white, large, full and of perfect form; the buds and flowers produced in clusters and freely furnished with a deep green moss. A valuable variety.

Crested Moss. Deep pink buds, surrounded with mossy fringe and crest; very beautiful and fragrant; growth slender.

Glory of Mosses. A moderate grower. Flowers very large, appear to best advantage when full; color pale rose.

Ienri Martin. Unusually well mossed buds opening to deep carmine blooms, shaded bright crimson, with mild, sweet fragrance. One of the best Moss Roses.

Princess Adelaide. A vigorous grower, pale rose and of medium size and good form. 


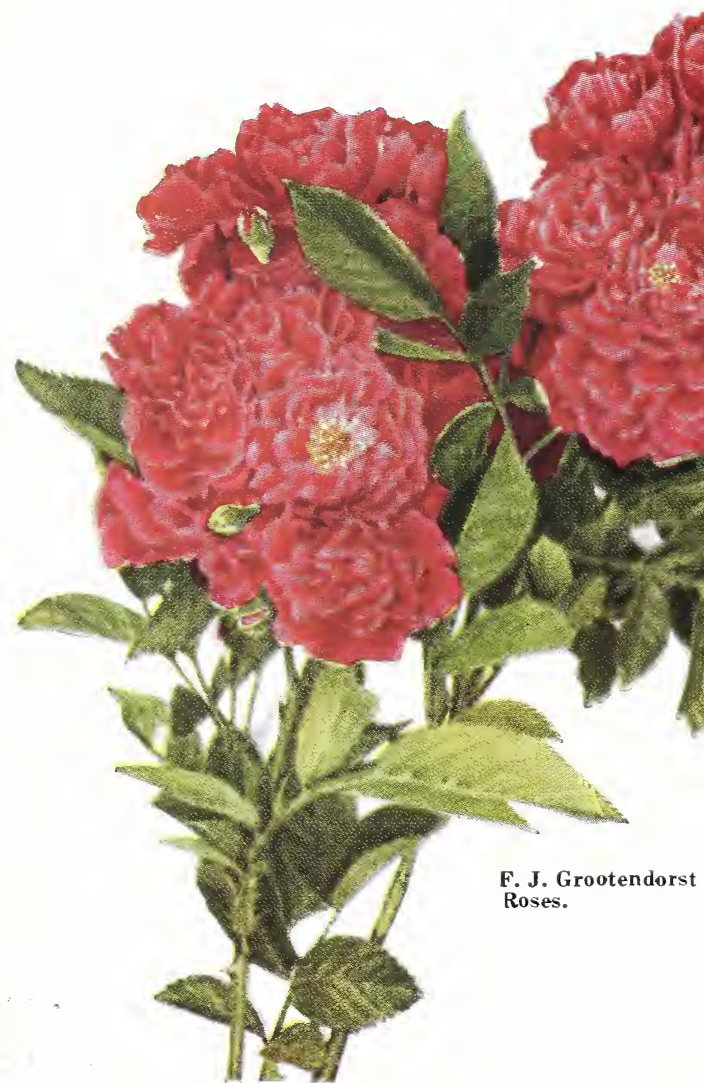

ROSES-Continued.

\section{Rosa Rugosa Rubra}

This class of Roses originated in Japan. They are very hardy, vigorous growers and not troubled with insects. They have thick, leathery, glossy green foliage, and the flowers are followed by bright scarlet seed pods, making them attractive in Fall. They are equally desirable as single specimens or hedge plants. Single red flowers.

\section{Hybrid Rosa Rugosa}

This valuable class of Roses is the result of crossing the Hardy Rosa Rugosa and our common garden Roses. This cross has given us varieties that will stand our Winter without protection, and give an abundance of bloom during the Summer. Most of these also retain the beautiful, dark green Pugosa foliage. We cannot urge too strongly the planting of these Roses.

Amelie Gravereaux. The small to medium sized buds are borne several together, opening to double, cupped, dark purplish red blooms of good fragrance and borne on long, strong stems. The plants are vigorous, producing blooms freely until Fall.

Belle Poitevine. Clusters of large, semidouble, open blooms of very dark crimson on medium long, strong stems. The plants produce an abundance of foliage, and bloom moderately but continuously all Summer.
Conrad F. Meyer. Color silvery rose, fragrant, large, very double, and blooms all summer. The foliage does not show so much of the Rugosa type as Blanch de Coubert. Has stood on our grounds without Winter protection, and came through in perfect condition. We consider it the best of its color.

F. J. Grootendorst. Beautiful, small, red flowers in clusters, with the edges of each petal serrated. The plant is a strong grower and bushy, with leathery, wrinkled, disease-resistant foliage, and blooms continuously till frost. A new type of Rose that has been described as a Rugosa plant with the blooms of a red carnation.

Hansa. Deep violet-red, double. Buds are borne in clusters and nearly all open at once. Has the true Rugosa foliage, and is one of the most valuable Roses we have. It is absolutely hardy.

Nova Zembla. A sport from Conrad F Meyer, inheriting all the good qualities of its parent with the added merit that the flowers are pure white, full and sweet scented; very fine. A Rose that will be widely planted.

Regina Badet. An unusually strong and vigorous grower, and very free bloomer. Large, round, stately flowers; color bright rosy carmine. Very fragrant and exceedingly beautiful.

Roseraie de l'Hay. Large, double, crimsonred blooms shading to rosy magenta and of delightful fragrance.

Sir Thomas Lipton. The best pure white Rugosa Rose. Strong and vigorous; grows four feet high. Flowers perfectly double, pure snowwhite. Fragrant, borne on long stems continuously throughout the season. Absolutely hardy everywhere. Splendid for hedging, cemetery and park work.

\section{Prairie or Bush Roses}

These are used more and more each year in landscape work for grouping amidst other shrubs. They are mostly single-flowered, are very hardy and need no protection.

Carolina. Marsh Rose. A tall growing wild Rose with single pink flowers, followed by showy red fruit. Prefers moist situations.

Rubiginosa. Sweetbrier. Most valued on account of its deliciously scented foliage. Flowers are single, pink.

Setigera. Prairie Rose. A hardy climbing Rose, with large, single, pink flowers in clusters, blooming after others are gone.

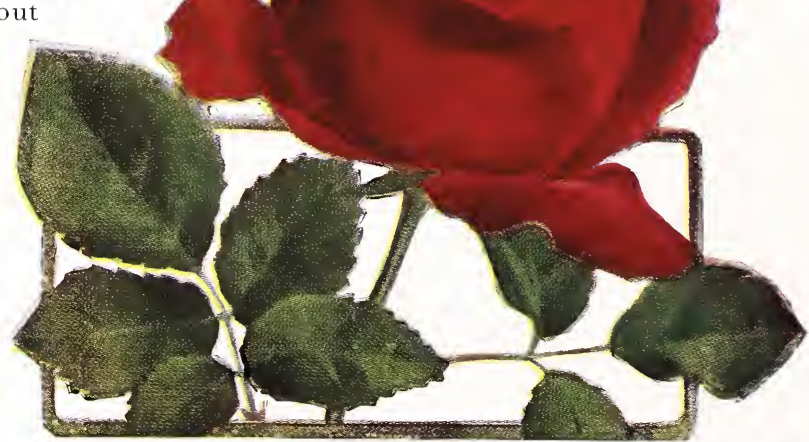

Roseraie de l'Hay Rose. 


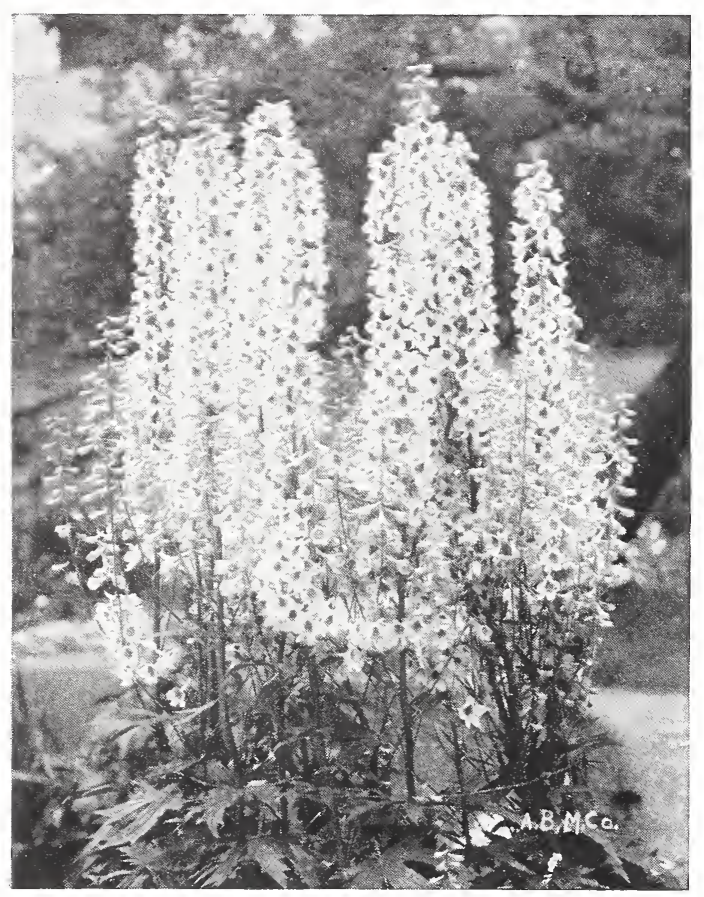

Delphinium-Larkspur.

PERENNIALS-Continued.

\section{Anemone - Windflower}

Very showy plants, with handsome foliage and bearing beautiful single flowers with yellow centers on long stems. Grows 2 to 3 feet high and blooms from september until cut down by frost. We have it in pure white.

\section{Boltonia - False Chamomile}

An Autumn flowering plant with thousands of aster-like flowers open at once. Produces a showy effect. Season is during August and September. 4 to 6 feet.

\section{Campanula - Bellflower}

Fine for border plants. The dwarf varieties are suitable for rock gardens.

Carpatica. Deep blue flowers all Summer; free bloomer; 8 to 10 inches high.

\section{Coreopsis - Tickseed}

Showy and valuable free flowering perennials, continuing in bloom the entire summer. Large yellow flowers on long stems; fine for cutting; early Summer until frost. 3 feet.

\section{Chrysanthemums}

The small flowered, hardy, pompon Chrysanthemums are becoming very popular again: they are the only perfectly hardy ones we have, and give showers of bloom long after frost in the Fall. We can supply red and white.

\section{Daisy, Shasta}

This is one of the Chrysanthemum family, growing 18 to 24 inches high and bearing during June and July great masses of daisy-like flowers, with white petals and yellow centers, 4 to 5 inches in diameter. It is raluable as a cut flower, as the blooms will last two weeks or longer in water. Very popular perennial.

\section{Delphinium - Larkspur}

These perennials are in bloom from June to September. Very hardy and of easy culture.

Belladonna (Everblooming Hardy Larkspur). The most beautiful sky-blue flowers. Blooms all summer till frost. 3 to 4 feet high.

Gold Medal Hybrids. One of the finest strains of mixed hybrids, consisting of the best named varieties with large flowers in various blue shades.

\section{Dicentra - Bleeding Heart}

spectabilis. The old-time favorite, with daintily lobed foliage and sprays of pink, heartshaped flowers. Blooms April to June. 2 feet high.

\section{Dianthus - Hardy Garden Pink}

Barbatus. The old-fashioned Sweet William. Assorted colors. $1 \frac{1 / 2}{2}$ to 2 feet high. June and July.

\section{Digitalis - Foxglove}

Flowers purple, pink or white, in long terminal racemes; two to three feet. June to August.

\section{Funkia - Day Lily}

The Funkias all make handsome, showy plants with beautiful, broad, ovate leaves, and large, lily-like, fragrant flowers in large clusters.

Lancifolia. Narrow lancelike leaves with spikes of lavender flowers. 1 foot.

Grandiflora. Pure white lily-like flowers. Profuse bloomer. 2 feet.

\section{Gypsophila - Baby's Breath}

Paniculata. 2 to 3 feet. Produces large panicles of very small white flowers. June, July and August. Fine for decorating in connection with high colored flowers.

\section{Gaillardia - Blanket Flower}

A genus of very ornamental, hardy plants. Flowers crimson and gold, 2 inches across, single on naked stems. Very showy. Early Summer until Autumn. Does well on light soil. Must have Winter protection.

\section{Hemerocallis - Yellow Day Lily}

Dumortieri. Very dwarf and compact, $1 \frac{1}{2}$ to 2 feet high, producing an endless number of large, lily-like blossoms of a bright orange color in June.

Flava (Lemon Lily). A pretty plant, with long, narrow leaves and flower stalks 2 to 3 feet high. These are crowned in June by beautiful lemon colored flowers.

Thunbergi. Beautiful lemon-yellow, fragrant flowers from July to September. Grows $1 \frac{1}{2}$ to 2 feet high.

\section{Hollyhock}

The well known tall and stately favorites of the old-time garden, but so much improved that they would not be recognized by the old growers. Pink, red, white and yellow. They bloom in July and continue for weeks.

\section{Rudbeckia - Golden Glow}

Laciniata. One of the best known of the hardy garden flowers. Blooms from July to september. 


\section{PERENNIALS-Continued.}

\section{Iris}

No flower in the perennial border surpasses the Iris in delicacy of texture and color, or is more showy and pleasing in general appearance. They rival the orchids of the tropics in beauty.

German. One of the most interesting of all perennials, with magnificent flowers in all colors. Has broad, lancelike foliage, and the wonderful flowers are produced on long stalks. May and June. Blue, pink, purple, variegated, white and yellow.

Japan. The most gorgeous of all the Irises, with large, flat flowers of three or six petals in all colors of the spectrum, veined, splotched and striped in a bewildering manner. Blooms in July after the German Iris is through.

Siberian Purple. We regard this as one of the most desirable plants for a border, or for marking lines, etc., known to us. It is very persistent, and will hold its own in blue grass sod. Foliage long, slender and graceful; flowers borne on slender stems about 18 inches to 2 feet high, usually two or three flowers on a stem. The flowers are a deep, clear purple and very graceful. It is perfectly hardy, and we consider it one of the most desirable of the Iris family.

Siberian White. Very similar to the purple variety, excepting the flowers are pure white.

\section{Lily-of-the-Valley}

This is as hardy as any plant can possibly be, and when planted in the open ground will increase rapidly.

\section{Monarda}

One of the showiest and most brilliant of our perennials, with large heads of fragrant scarlet flowers. Will grow $1 \frac{1}{2}$ to $2 \frac{1}{2}$ feet high, and flourish in any soil. Is a beautiful adornment to the flower garden.

\section{Pachysandra - Japanese Spurge}

Terminalis. A trailing plant 6 to 8 inches high, forming broad mats of bright glossy green foliage and small spikes of flowers during May and June. A ground cover, which will grow in all shady situations and the only plant which will thrive under pine trees.

\section{Peonies}

Fine hardy plants, rivaling the rose in perrection of bloom and coloring, and requiring little care, as they thrive and do well in any soil. Colors range from pure white to deep crimson. Can be planted in September or October and in the Spring. Those listed are double unless indicated.

Imerican Beauty. Tate bloomer; unusually fragrant; strong grower. Stands out very prominent among the late Peonies on account of its color and size. Resembles American Beauty rose in color; very double.

Defiance. Single flowering; early bloomer. This is one of the best single flowering varieties; blooms profusely; color light red.

Delicatissima. Pale lilac-rose. Midseason. Extra good keeper and shipper. Similar to Floral Treasure.

Duchesse de Nemours. Sulphur-white with greenish reflex. One of the finest for cut flowers.

Edoward Andre. Globular bloom, deep crimson-red with black shading, metallic reflex stamens golden yellow; magnificent coloring.

Edulis Superba. Very large bloom of perfect shape, fine brilliant pink shaded violet, intermixed with narrow whitish petals, silvery reflex; one of the best early cut flower varieties.

Felix Crousse. (See color engraving on page 43). Brilliant red, ball-shaped bloom; the popular color with florists; rather late.

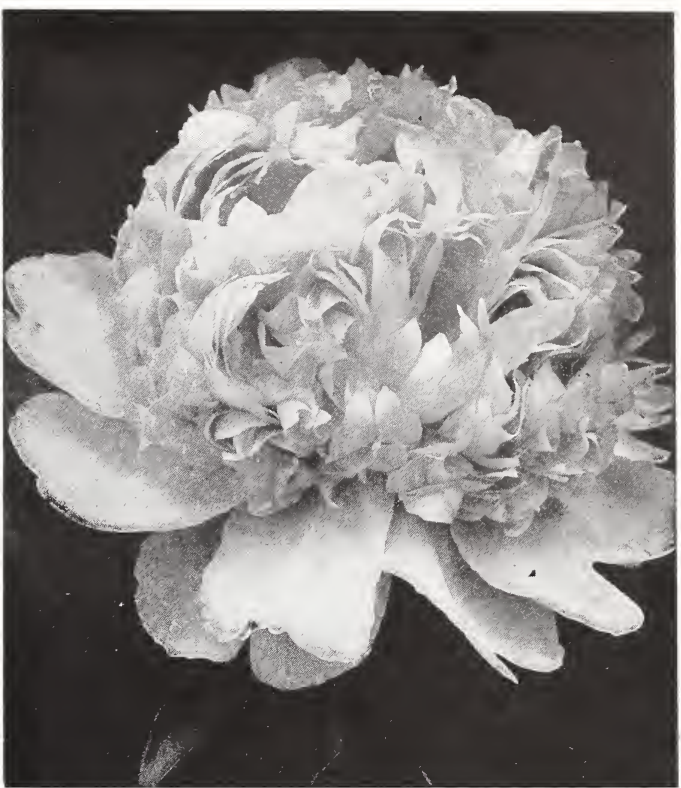

Edulis Superba Peony.

Festiva Alba. Large, globular, pure white with a few spots of carmine in the center; beautiful and sweet.

Festiva Maxima. (See color engraving on page 43). This is the most beautiful of all white Peonies. The flowers are of extra large size, in clusters, and petals as fine as silk. Color pure white, with a crimson drop in the center.

Floral Treasure. Color bright pink; very large and double, exquisitely fragrant; a splendid bloomer.

Francois Ortegat. A midseason to late variety, being very dark rose color with yellow stamens; flowers large on strong stems. Extra good.

Grandiflora Rubra. Large; late; fine form; blood-red.

Golden Harvest. Very large bloom, blush guard petals, creamy white center; midseason. One of the freest bloomers.

Louis Van Houtte. Dark red, the richest color of our collection; medium season, very early and free blooming. The king of the dark reds, as seen at a distance it fairly glows like a ball of fire. Very striking and effective in bouquets

Madame de Verneville. Bomb type; early One of the best varieties on the market. Guard petals pure white, very large; the blooms are very full and double, of the purest white except a few cream colored petals and four red flakes on central petals. Has the true June rose fragrance.

Marie Lemoine. Large, very compact flower sulphur white, occasionally carmine tipped. Very late. Extra good commercial variety.

Messionier. One of the old reliable varieties color crimson; very double. Valuable for cut flowers

Prince Imperial. Brilliant purplish searlet, free bloomer. Fine for massing in landscape work.

Victorie Tricolore (Van Houtte). Rose-pink and salmon: an excellent bloomel. 


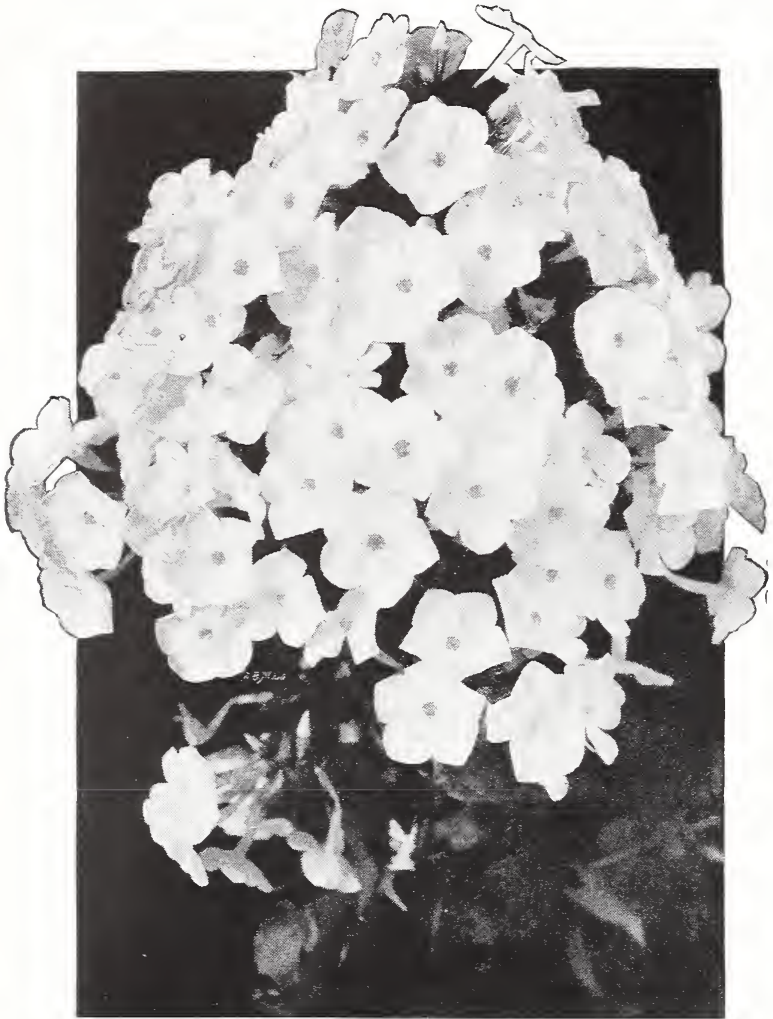

Hardy Garden Phlox.

PERENNIALS-Continued.

\section{Hardy or Garden Phlox}

\section{(Phlox paniculata)}

One of the favorites of long ago, in which great improvement has been made by cultivation. From the old-time clusters of purplish pink flowers has been evolved a most magnificent family of hardy perennials, bearing enormous trusses of magnificent flowers in every conceivable shade of color.

Bridesmaid. Pure white with crimson eye.

Eclaireur. Purplish crimson, with lighter center. An early and continuous bloomer; flower large.

Jeanne d'Arc. Pure white, very fine; late.

Le Mahdi. Deep purplish violet, with darker eye.

Mrs. Jenkins. White; immense panicles; free bloomer.

Pantheon. Deep salmon-rose.

G. A. Strohlein. Beautiful variety. Scarletorange flowers, with bright carmine eye; extra large flowers; enormous clusters.

R. P. Struthers. Bright rosy red, crimson eye. One of the best varieties.

Ryndstrom. Color a lively shade of rosepink, much like Paul Neyron rose; flowers very large. One of the best for massing.

Richard Wallace. White, rosy center.

Von Lassburg. Pure white; very large.

\section{Physostegia - False Dragon Head}

The Virginiana is probably the most desirable one of this group. During September and October it bears spikes of bright pink flowers. 3 feet.

\section{Poppy, Oriental}

For a gorgeous display of rich brilliant coloring nothing can excel the Oriental Poppies during their period of flowering in May or June, and whether planted singly or in masses their large flowers and freedom of bloom render them conspicuous in any position.

\section{Rose Mallow - Hibiscus}

The Hibiscus are valuable border plants, having handsome broad leaves and large, showy blossoms.

\section{Sedum - Stonecrop}

Spectabile. A dwarf plant with light, fleshy, glaucous foliage, and covered with flat heads of pink flowers that are retained on the plant for a long time. Will grow almost anywhere excepting moist places. Indispensable for late planting.

\section{Tiger Lily}

Bright orange scarlet with dark spots; a strong growing, showy variety, and entirely hardy. Succeeds well everywhere.

\section{Veronica - Speedwell}

Longifolia subsessilis. 2 feet. July to September. One of the handsomest blue flowering plants. Perfectly hardy and increases in strength and beauty each year. Spikes completely studded with beautiful blue flowers; fine for cutting and one of the best plants for the hardy border.

\section{Yucca Filamentosa}

Creamy white, bell-shaped flowers in July, borne in great profusion on a magnificent stalk, 4 to 5 feet high. Fine for planting in front of evergreens.

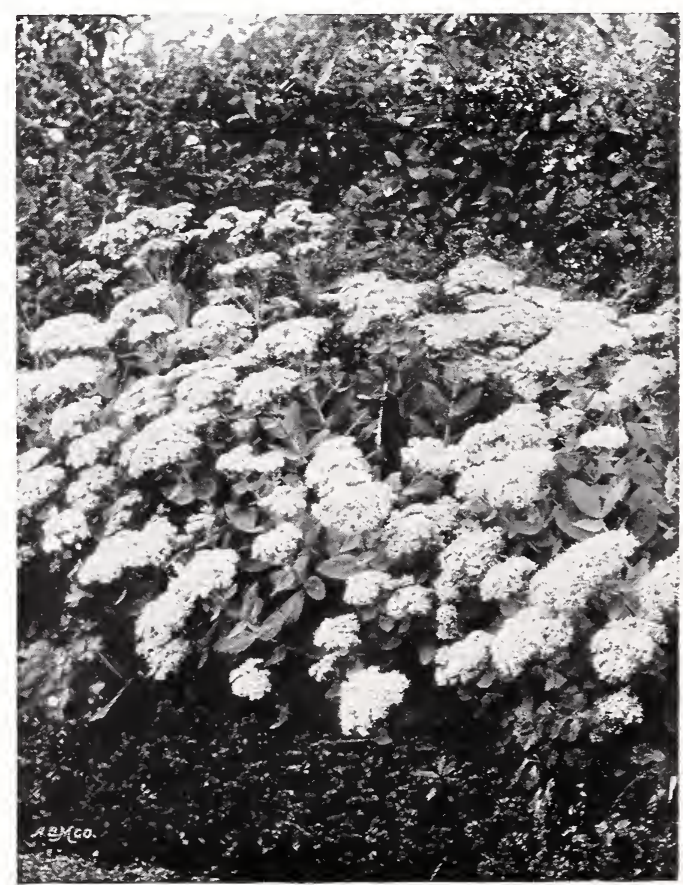

Sedum-Stonecrop. 


\section{Climbing Vines}

\section{Ampelopsis - Ivy}

Virginia Creeper or American Ivy (Quinquefolia). A perfectly hardy, rapid climber, with large, five-lobed leaves which change to bright scarlet or crimson in Autumn.

Engelmann Ivy. Shorter jointed and having finer foliage than Quinquefolia. Clings to brick or stone. A good grower and hardy. The best for the North and Northwest.

Boston or Japan Ivy (Veitchi). From Japan. It is a splendid plant for covering any object, as it elings perfectly to the smoothest surfaces. The foliage is a bright glossy green, changing to bright tints of scarlet, crimson and orange. Kills back some in a cold, dry climate.

\section{Aristolochia}

Dutchman's Pipe (Sipho). A native species of climbing habit and rapid growth, with magnificent light green foliage, 10 to 12 inches in diameter, and curious, pipe-shaped, yellowish brown flowers; a splendid variety for archways or verandas.

\section{Clematis}

This family of plants is noted for its rapid, slender growth, delicate foliage and profusion of bloom through the Summer. They do best in rich soil, and where they can have plenty of sun. We give a few of the best only. Give Winter protection in this section.

Henryi. A robust plant and free bloomer. Flowers creamy white. A hybrid of C. lanuginosa and C. florida, but not resembling the former.

Jackmani. Flowers are large, intense violetpurple. Remarkable for its velvety richness. It is a free grower and an abundant bloomer. The petals have a ribbed bar down the center; broad central tuft of pale green stamens.

Madame Edouard Indre. Flowers a beautiful, bright, velvety red.

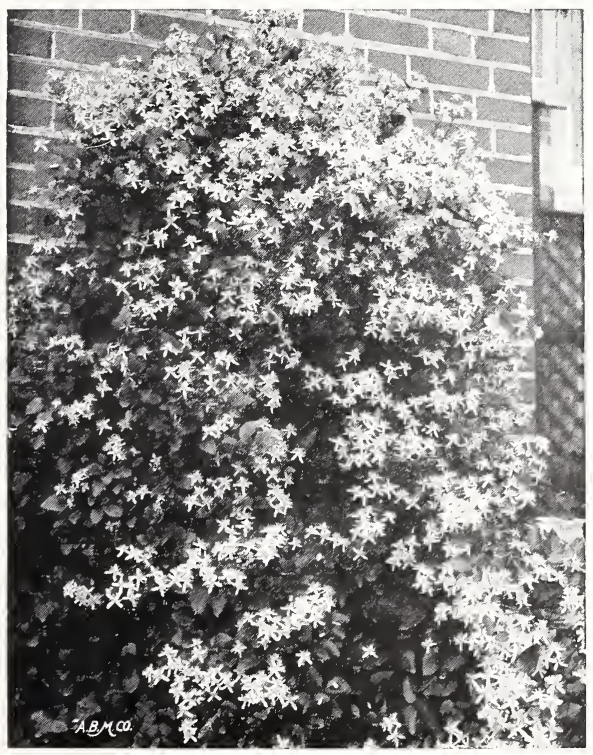

Clematis Paniculata.

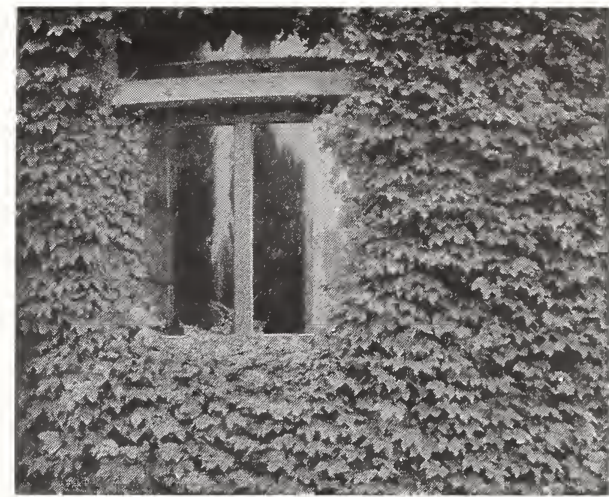

Engelmann Ivy.

Paniculata. One of the most desirable and beautiful hardy garden vines, being a luxuriant grower and profuse bloomer, and possessing fine foliage; particularly useful for covering verandas, pillars, fences, etc. Flowers are medium size, star-shaped.

\section{Celastrus - Bittersweet}

Bittersweet (Scandens). A native climbing or twining plant, with fine, large leaves, yellow flowers and clusters of orange capsuled fruit. It grows 10 to 12 feet in a season.

\section{Climbing Honeysuckle - Lonicera}

Favorite vines with delightfully fragrant flowers. Perfectly hardy and adaptable to any purpose.

Hall's Japan (Halliana). An almost evergreen variety, with pure white flowers, changing to yellow; very fragrant and a vigorous grower. Covered with flowers from July to October. Best blooming of all.

Monthly Fragrant (Belgica). Flowers red and pale yellow; sweet scented; blooms through the Summer.

Scarlet Trumpet (Sempervirens). Flowers deep red, trumpet-shaped; flowers all summer; a native climber and appropriate for trellises and rockwork. One of the handsomest.

\section{Lycium - Matrimony Vine}

A vigorous climbing vine, with small, starshaped, purple flowers, succeeded by bright scarlet berries, which remain on the vine all Winter. It is hardy and will thrive almost anywhere.

\section{Tecoma - Trumpet Flower}

Trumpet Creeper (Radicans). A splendid, hardy, climbing plant, with large, trumpetshaped searlet flowers in August.

\section{Wisteria}

Chinese Purple Wisteria (Sinensis). One of the most elegant and rapid growing of all climbing plants; attains immense size; has long, pendulous clusters of pale hlue flowers in May and June; also blooms late in Autumn. 


\section{Bulbs and Tuberous Rooted Plants \\ For Spring Planting}

\section{Canna}

Stately and highly ornamental plants, for both flowers and foliage. They attain a height of 2 to 5 feet, and may be grown singly or in masses. Leaves green or brownish red; flowers scarlet, crimson, yellow, cream, etc., variously marked.

\section{Dahlias}

The Dahlia is coming to the front.in the ranks of Summer flowering plants. There is nothing that can equal them in range of color and abundance of bloom. They are splendid for cut flower work and command attention wherever grown. Plant in good, rich garden soil; set three feet apart and for best results allow but one stalk in a hill; before freezing weather, dig and store in frost-proof cellar. We can supply a choice collection of colors.

\section{Gladiolus}

The Gladiolus is the most attractive of all the Summer flowering bulbs, and deserves a place in every garden, as it is sure to flower and do well with very little care. Set the bulbs from 6 to 9 inches apart, and about 4 inches deep. Plant from middle of March to first of June. We can supply choice varieties.

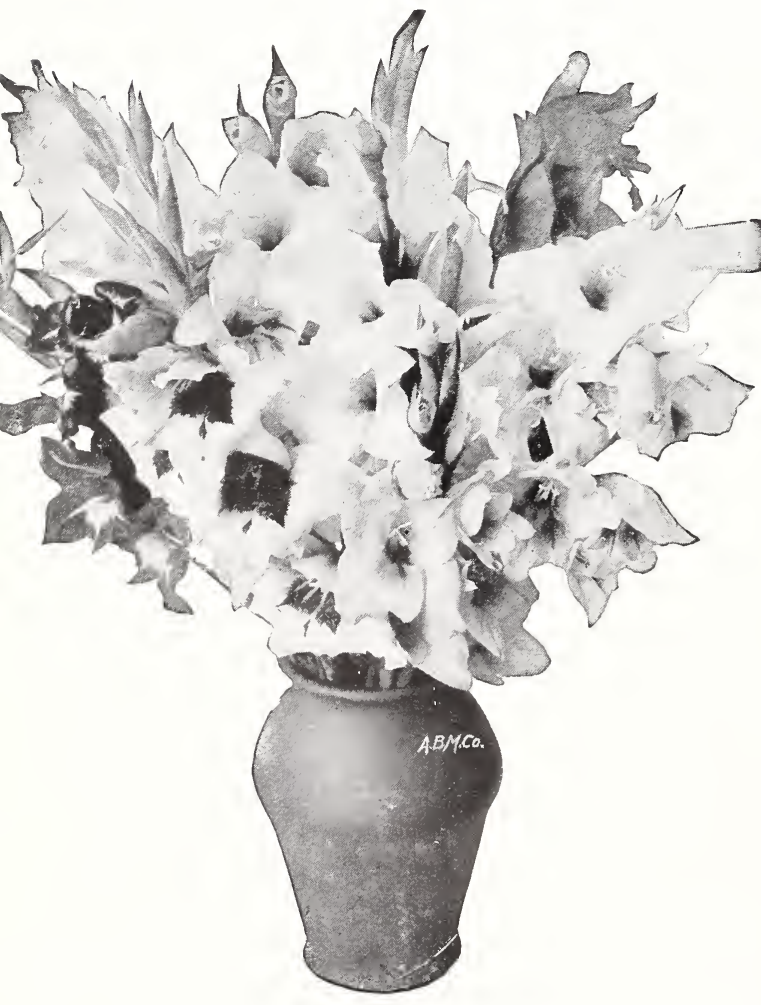

Gladioli.

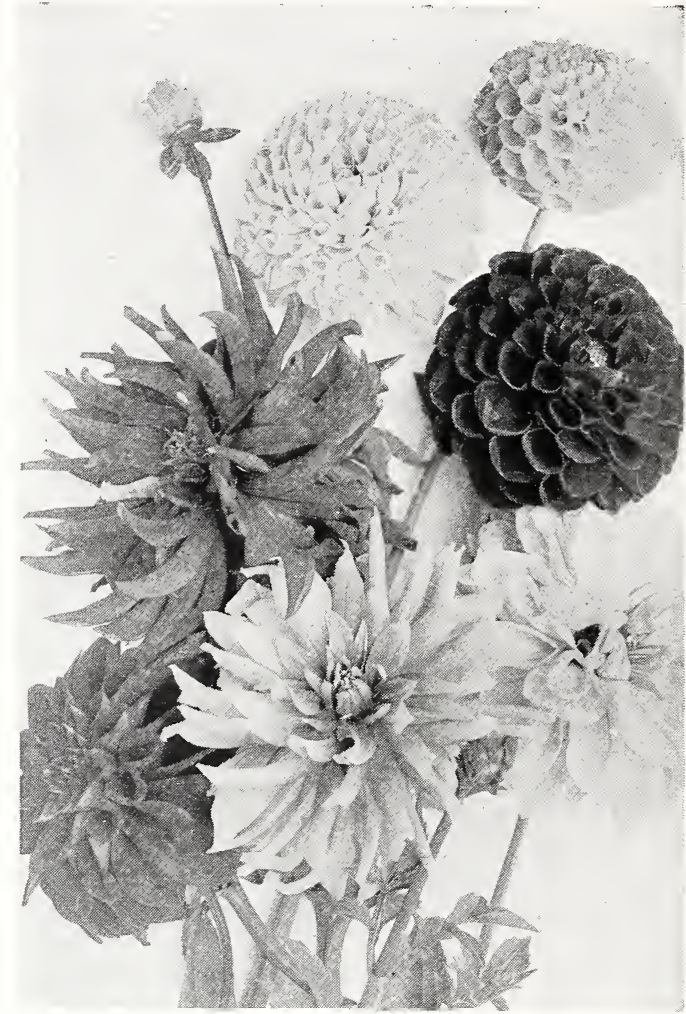

Dahlias.

\section{Bulbs for Fall Planting \\ Crocus}

A universal favorite; one of the earliest garden ornaments; should be planted about two inches deep. Blue, white, yellow and striped.

\section{Hyacinths}

The most beautiful and fragrant of early Spring flowering bulbs, much used for Winter forcing. Pink, red, purple, violet and white.

\section{Narcissus}

Pretty varieties of the Narcissus, having a very agreeable fragrance; adapted to either pots or outdoor culture.

Paper-White Grandiflora, Large Flowering. This large flowering type is such an improvement over the ordinary "Paper-White" that we have discontinued offering the latter. The "Large Flowering" is more vigorous and earlier, producing purest snow-white flowers of large size and good substance. This Narcissus does splendidly when grown in bowls of water and pebbles or moss.

\section{Tulips}

We know of nothing that for the money invested will give a more gorgeous show during early Spring and there is nothing more easily grown than the Tulip. Should be planted in October or November. 


\section{How and When to Spray}

\begin{tabular}{|c|c|c|c|}
\hline PLANT & $\begin{array}{l}\text { FInst } \\
\text { Application }\end{array}$ & $\begin{array}{l}\text { Becond } \\
\text { Application }\end{array}$ & $\begin{array}{l}\text { Third } \\
\text { Application }\end{array}$ \\
\hline $\begin{array}{l}\text { APPLE- } \\
\text { Canker worm, eodling moth, } \\
\text { scab. }\end{array}$ & $\begin{array}{l}\text { Spray before buds start, } \\
\text { using Bordeaux. }\end{array}$ & $\begin{array}{l}\text { After the blossoms have } \\
\text { formed, but before ther } \\
\text { o pen. Bordeaux. Paris } \\
\text { green. }\end{array}$ & $\begin{array}{l}\text { Within a week after blos- } \\
\text { soms have fallen, Bordeaux } \\
\text { and Paris green. }\end{array}$ \\
\hline $\begin{array}{l}\text { CHERRY- } \\
\text { Rot, aphis, cureulio and slue. }\end{array}$ & $\begin{array}{l}\text { Before buds start, use } \\
\text { Bordeaux. For aphis, kero- } \\
\text { ene emulsion. }\end{array}$ & $\begin{array}{l}\text { When fruit has set, Bor- } \\
\text { deave and Paris green." }\end{array}$ & $\begin{array}{l}10 \text { to } 12 \text { days later, if } \\
\text { signs of rot appear, repeat. }\end{array}$ \\
\hline $\begin{array}{l}\text { CURRANT, } \\
\text { GOOSEBERRY- } \\
\text { Worms, mildew. }\end{array}$ & $\begin{array}{l}\text { As soon as worms are } \\
\text { seen, Paris green. }\end{array}$ & $\begin{array}{l}\text { If they reappear, repeat, } \\
\text { adding Bordeaux for mil- } \\
\text { dew.t }\end{array}$ & $\begin{array}{l}\text { If worms till trouble. } \\
\text { hellebore. }\end{array}$ \\
\hline $\begin{array}{l}\text { GRAPE- } \\
\text { F?er-beetle, fungous } \\
\text { eases. }\end{array}$ & $\begin{array}{l}\text { Before buds burst. } \\
\text { deaux and Paris green. }\end{array}$ & $\begin{array}{l}\text { When first leaves are half } \\
\text { grown Bordeaux and Paris } \\
\text { green. }\end{array}$ & $\begin{array}{l}\text { As soon as Iruit has set, } \\
\text { repeat. }\end{array}$ \\
\hline $\begin{array}{l}\text { PEAR } \\
\text { Leaf blight, scab, psylla and } \\
\text { codling moth. }\end{array}$ & $\begin{array}{l}\text { Before buds start. Bor- } \\
\text { deaux. }\end{array}$ & $\begin{array}{l}\text { Within a week after blos- } \\
\text { soms fall, Bordeaux and } \\
\text { Paris green. }\end{array}$ & 10 to 12 days later, re \\
\hline $\begin{array}{l}\text { PLUM- } \\
\text { Black knot, rot and all } \\
\text { fungous diseases and cur- } \\
\text { culio. }\end{array}$ & $\begin{array}{l}\text { As buds start, Bordeau: } \\
\text { Cut out knot and burn. }\end{array}$ & $\begin{array}{l}\text { When fruit has set, Bor- } \\
\text { deaux and Paris green." }\end{array}$ & $\begin{array}{l}10 \text { to } 12 \text { days later, } \\
\text { peat. }\end{array}$ \\
\hline $\begin{array}{l}\text { RASPBERRY, BLACK- } \\
\text { BERRY- } \\
\text { Anthracnose, rust. }\end{array}$ & $\begin{array}{l}\text { Cut out badly disegsed } \\
\text { canes. Spray with Ber- } \\
\text { deaux, before growth starts. }\end{array}$ & $\begin{array}{l}\text { When new canes are one } \\
\text { toot high, spray with Bor- } \\
\text { deaux mixture. }\end{array}$ & peatit 10 to 14 days later, \\
\hline $\begin{array}{l}\text { STRAWBERRY- } \\
\text { Rust. }\end{array}$ & $\begin{array}{l}\text { Just before blossom opens. } \\
\text { Bordeaux and Paris green." }\end{array}$ & $\begin{array}{l}\text { When fruit has set, Bor- } \\
\text { leaux.* }\end{array}$ & $\begin{array}{l}\text { As soon as berries are } \\
\text { harvested. Bordeaux, if to } \\
\text { he kept longer. }\end{array}$ \\
\hline
\end{tabular}

\section{SPECIAL NOTES}

For Black Knot on cherries and plums, eut out and destroy by burning the diseased. parts as soon as dis. covered.

For Aphis on all plants, use kerosene emulsion or Ivory sosp.

If Red Rust appears on raspberries or blackberries, the entire stools affected should be cut out and burned.

Young Plants should be sprayed with Bordeaux mix. ture at the time of the first and third application to bering plants.

\section{EXPLANATION}

Whenever an asterisk (*) is used, it cautions against spraying with poison while the plants are in blossom: a dagger $(\dagger)$ indicates that there is danger of making an application within three weeks of the time the fruit is to be used as food. While the number of applications recommended will be found desirable, in seasons when the fungi are less troublesome a smaller number may often suffice. Always strain ingredients used into the sprayer to avoid elogging the sprayer.

\section{Spraying}

Each year's experience shows more plainly that to grow nice, smooth fruit we must spray. The main things for us to combat are:

Biting Insects-Such as codling moth (apple worm), currant worm, curculio, etc.

Sucking Insects-The green, red and black aphis.

Fungus-Apple scab, plum rot, currant and gooseberry mildew. While we may not be able-to do away with Fungus Apple scab, plum rot, currant and gooseber them and successfully grow fine fruit. One must begin these pests altogether, we can, do a great extent, control them and successfully grow following are the best known remedies at the present time:

\section{INSECTICIDES}

For Blting Insects:

Paris Green Mixture:

Paris Green $\ldots \ldots \ldots \ldots \ldots \ldots \ldots \ldots \ldots \ldots \ldots$ pound

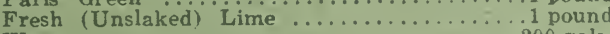

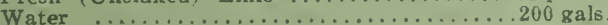

Hellebore Solution:

White Hellebore (fresh) ............... ounce

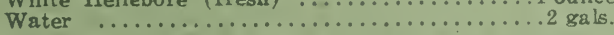

There is no danger in using Hellebore solution on currants and gooseberries after the fruit is formed.

For Sucking Insects:

Kerosene Emulsion-Dissolve one pound of hard soap in two gallons of boiling water. Remove from fire and while hot add two quarts of kerosene. Churn or shake the mixture until it assumes a creamy consistency. This should be done while hot. To this add six gallons of water bofore using.

\section{FUNGICIDES}

Bordeaux Mixture:

Copper Sulphate ................. pounds

Fresh Lime $\ldots \ldots \ldots \ldots \ldots \ldots \ldots \ldots \ldots \ldots$ pounds

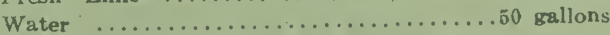

The copper sulphate and lime should be dissolved and prepared in separate vessels (wood or fiber). After the sulphate is dissolved and the lime slaked, they should be thoroughly mixed. The color of the mixture should be an intense blue.

When spraying for hoth biting insects and fungus, the Paris green and Bordeaux mixture may be mixed and in this way perform two operations at once. 
